NBER WORKING PAPER SERIES

\title{
WAR, SOCIALISM AND THE RISE OF FASCISM: AN EMPIRICAL EXPLORATION
}

\author{
Daron Acemoglu \\ Giuseppe De Feo \\ Giacomo De Luca \\ Gianluca Russo \\ Working Paper 27854 \\ http://www.nber.org/papers/w27854 \\ NATIONAL BUREAU OF ECONOMIC RESEARCH \\ 1050 Massachusetts Avenue \\ Cambridge, MA 02138 \\ September 2020
}

We thank Luigi Pascali, Giacomo Ponzetto, Riccardo Puglisi, Guido Tabellini, Joachim Voth and the participants to the CEPR Political Economy Webinar for useful comments and suggestions. We would also like to thank Amos Conti, Annagrazia De Luca, Stefano Presti and Raffaele Savarese for the assistance provided in data collection and digitization and gratefully acknowledge the financial support of the Morrell Trust and the extensive support received by the employees of the many state archives and libraries visited around the country, in particular the director of the National Central Library of Florence, Luca Bellingeri, and Gian Luca Corradi, Enrico Leonessi, Annalisa Moschetti, Annalisa Pecchioli and Lina Tavernelli. This paper combines two independent working papers, "War, Socialism and the Rise of Fascism: An Empirical Exploration" by Acemoglu, De Feo and De Luca and "World War One and the Rise of Fascism in Italy" by Russo. The views expressed herein are those of the authors and do not necessarily reflect the views of the National Bureau of Economic Research.

NBER working papers are circulated for discussion and comment purposes. They have not been peer-reviewed or been subject to the review by the NBER Board of Directors that accompanies official NBER publications.

(C) 2020 by Daron Acemoglu, Giuseppe De Feo, Giacomo De Luca, and Gianluca Russo. All rights reserved. Short sections of text, not to exceed two paragraphs, may be quoted without explicit permission provided that full credit, including $\odot$ notice, is given to the source. 
War, Socialism and the Rise of Fascism: An Empirical Exploration

Daron Acemoglu, Giuseppe De Feo, Giacomo De Luca, and Gianluca Russo

NBER Working Paper No. 27854

September 2020

JEL No. D72

\begin{abstract}
$\underline{\text { ABSTRACT }}$ share for Christian Democrats after World War II in areas with greater early Fascist activity.

Daron Acemoglu

Department of Economics

MIT

50 Memorial Drive

Cambridge, MA 02142-1347

and NBER

daron@mit.edu

Giuseppe De Feo

University of Leicester

School of Business

Brookfield Campus

266 London Road

Leicester LE2 1RQ

United Kingdom

gdf9@leicester.ac.uk

Giacomo De Luca

Free University of Bozen

giacomo.deluca@unibz.it

Gianluca Russo

Boston University

270 Bay State Rd

Boston, MA 02215

russog@bu.edu
\end{abstract}

The recent ascent of right-wing populist movements in many countries has rekindled interest in understanding the causes of the rise of Fascism in inter-war years. In this paper, we argue that there was a strong link between the surge of support for the Socialist Party after World War I (WWI) and the subsequent emergence of Fascism in Italy. We first develop a source of variation in Socialist support across Italian municipalities in the 1919 election based on war casualties from the area. We show that these casualties are unrelated to a battery of political, economic and social variables before the war and had a major impact on Socialist support (partly because the Socialists were the main anti-war political movement). Our main result is that this boost to Socialist support (that is "exogenous" to the prior political leaning of the municipality) led to greater local Fascist activity as measured by local party branches and Fascist political violence (squadrismo), and to significantly larger vote share of the Fascist Party in the 1924 election. We document that the increase in the vote share of the Fascist Party was not at the expense of the Socialist Party and instead came from right-wing parties, thus supporting our interpretation that center-right and right-wing voters coalesced around the Fascist Party because of the "red scare". We also show that the veterans did not consistently support the Fascist Party and there is no evidence for greater nationalist sentiment in areas with more casualties. We provide evidence that landowner associations and greater presence of local elites played an important role in the rise of Fascism. Finally, we find greater likelihood of Jewish deportations in 1943-45 and lower vote 


\section{Introduction}

As we approach the centennial of the March on Rome in 1922, which catapulted Benito Mussolini's fascists to power in Italy, there is renewed interest in fascism, partly as a result of the rise of right-wing authoritarian populist movements around the world (e.g., Stanley, 2018). There is, however, little agreement on what led to the rise of fascist politics in interwar Europe in the first place. Prominent theories range from cultural ones (e.g., Sternhell et al., 1994) to social psychological ones (e.g., Lasswell, 1933; Fromm, 1941; Adorno et al., 1950; Laclau, 1977), to sociological ones (e.g., Ortega Y Gasset, 1932; Parsons, 1942; Lipset, 1955) and to historical approaches such as those of Moore (1966), Griffin (1991) and Kershaw (2015). One of the most enduring areas of disagreement has been the relationship between socialism and fascism. The German historian Ernst Nolte (1965), as well as several Marxist historians, have emphasized that fascism, and the support it received from both the upper and middle classes, was related to the threat of socialism in the immediate aftermath of WWI (see for example Snowden, 1972; Corner, 1975; Demers, 1979; Cardoza, 1982; Lyttelton, 2003). Yet several other historians have disagreed with this interpretation (e.g., Griffin, 1991; Sternhell et al., 1994). This debate is not just academic. If Fascism was unique to a period in which World War I and the Soviet revolution had created a threat of socialist revolution in continental Europe, then there may be less reason to fear that today's right-wing authoritarian and populist movements will turn fascist.

In this paper, we contribute to this debate by providing evidence that the (perceived) threat of socialism was critical to the rise of fascist politics in Italy. The Italian Socialist Party was one of the strongest in Europe in the first quarter of the 20th century and was committed to the hard-line socialist/communist agenda (Tasca, 1938). After the 1917 Bolshevik revolution, it allied itself with the Soviet Russia. Because it had opposed Italy's entry into World War I, the hardship suffered by Italians who served in the war and those who remained behind created a groundswell of support for the party, which captured $32.3 \%$ of the national vote in the 1919 elections (Maier, 1988, p. 129). At this point, the Fascist Party lacked a coherent program and did not even manage to compete effectively in the election. Subsequently, however, the Fascists started receiving support from many local elites and middle-class Italians alarmed by the socialist threat (De Felice, 1965). By 1920, the Fascists were better organized, received monetary and political backing from many anti-socialist landowners and businessmen, and had started carrying out systematic violence against Socialists and other politicians and organizations that opposed them. By 1924, a significant fraction of the right-wing and center-right vote shifted to the Fascist Party, which received more than $65 \%$ of the vote in the parliamentary elections (Direzione Generale della Statistica, 1924). In the words of Tasca (1938, p. XVI),

"On November 16, 1919, in the first general election since the war, Mussolini obtained only 5000 votes in Milan [...]. The socialist paper Avanti announced ironically that a corpse had been fished up from the bottom of the Naviglio canal in an advanced state of decay - Mussolini's. 
A year and half later the 'corpse' [...] was elected at the head of the candidates of the national bloc in two constituencies, Milan and Bologna. After the beginning of 1922 the fascist advance became an avalanche, and Mussolini left Milan in a sleeping-car on the evening of October 29 to 'march' on Rome, where he had been invited by the king to form a cabinet. This rapid success, which on the face of it seems little short of miraculous, was the result of a combination of factors, $[\ldots]$ and above all from the world war and its repercussions."

Our empirical strategy is to investigate the linkage between the threat of socialism and the rise of fascist politics in Italy. We first substantiate the aforementioned claim that the war's hardship created a big boost to the Socialist Party in the 1919 election. We use the military Roll of Honor to obtain estimates of Italian casualties by municipality during WWI. We document that the casualties of footsoldiers in a municipality were unrelated to any prior political, economic, social or demographic aspects of municipalities. Nevertheless, we show that municipalities with high casualties (and thus with greater exposure to the war) experienced a sizable increase in the vote share of the Socialist Party in the 1919 elections (relative to the 1913 elections). We interpret the WWI casualties as an exogenous source of variation in Socialist support and trace the subsequent political responses to this variation.

Our main finding is that in municipalities experiencing this boost to Socialist support saw a powerful Fascist response. In particular, we estimate greater likelihood of local Fascist branches and more Fascist violence in the 1920s, and significantly higher Fascist vote share in the 1924 elections in these areas. Our estimates suggest that as much as 15\% of the increase in the vote share of the Fascist lists from 1919 to 1924 may have been due to to the consolidation of the right-wing and center-right vote under the auspices of this party in the face of the perceived red scare.

We bolster this interpretation with several exercises. First, we show that the source of variation we exploit is unlikely to be confounded by other, competing explanations. For example, we do not find a consistent support from veterans for the Fascist Party, and our instrument does not predict the building of nationalist (war) memorials. Second, we demonstrate that the increase in the vote share of the Fascist Party was not at the expense of the Socialist Party. Third, we document that the shift towards the Fascist Party was stronger when the threat of socialism coincided with a larger fraction of elites and urban middle classes, and provide additional evidence that this is both because some of the elites supported the Fascist Party and the local "petty bourgeoisie" switched its allegiance from center-right parties to the Fascists.

Furthermore, if the rise of Fascism was partly a response to the threat of socialism, then other shocks intensifying Socialist support should have similar effects. We document that this is the case, exploiting rainfall variation, leading to drought in some municipalities, and the differential effects of the Spanish flu epidemic across municipalities. In both cases the results are not as precise as our main estimates, but are consistent with a causal channel working from hardship to support for the Socialist Party and from there to subsequent rise of the Fascist Party in the early 1920s. 
Finally, we explore two longer-term effects of Fascism. First, we show that support for Fascism is associated with greater likelihood of Jews being deported from the area during 1943-45, presumably reflecting local collaboration with the Nazis. Second, we document that in the post-Fascist era elections, in municipalities where the Fascist Party was more successful, center-right parties performed significantly worse and center-left and other left-wing parties performed better. This may have been because their alliance with the Fascists in the 1920s may have partly delegitimized center-right establishment.

In addition to the historical literature discussed previously, our paper is related to a few works in political economy. A recent strand of literature analyzes the roots of the Nazi movement in Germany. Voigtländer and Voth (2012) document the links between anti-Semitic pogroms in the Middle Ages and support for the Nazi Party, while Satyanath et al. (2017) demonstrate the role of local associations. Adena et al. (2015) and Voigtländer and Voth (2019) explore the effects of radio propaganda and public works, such as the building of the Autobahn network, on Nazi support. Recent work by Koening (2015) investigates the link between returning war veterans and support for right-wing parties in Germany. ${ }^{1}$ Even more closely related to our work are a few papers that show the effects of economic disruption and hardship on later Nazi support. In particular, Galofré-Vilà et al. (2017) and King et al. (2008) focus on the effects of the Great Depression, while Doerr et al. (2020) explore the consequences of the 1931 banking crisis.

There are fewer econometric studies of the rise of Italian Fascism, though there is a sizable history and sociology literature, already mentioned above. Most closely related to our work are Elazar (2000) and Elazar and Lewin (1999), who emphasize the role of Fascist violence and document a province-level correlation between Socialist support, Fascist violence and the Fascist military take-over of the provinces. These papers do not have the detailed municipal-level data we use, do not attempt to exploit potentially exogenous variation in Socialist support, and do not explore any of the mechanisms we propose. Brustein (1991) and Wellhofer (2003), on the other hand, note the correlation between Socialist politics in 1919 and subsequent Fascist success, but suggest that this may be due to disaffected Socialist voters switching to the Fascist Party, a possibility we explore in our analysis. The causal mechanism here is also related to Acemoglu et al. (2019), who argued that the rise of the Sicilian Mafia in the last decade of the 19th century was a response to the rise of Socialist peasant organizations following the severe drought of $1893 .^{2}$

The rest of the paper is organized as follows. The next section provides the historical context. Section 3 presents our data and its sources. Section 4 explores the relationship between footsoldier casualties and the support for the Socialist Party in the 1919 elections, which will be our first stage. Section 5 presents our main results, focusing on the Fascist vote share in 1924 and other measures of early Fascist activity. Section 6 provides evidence on our proposed mechanism, that the rise of Fascism was related to the perceived threat of socialism, while Section 7 presents estimates using alternative sources of variation. Section 8 looks

\footnotetext{
${ }^{1}$ See also Berg et al. (2019) for similar evidence from Sweden.

${ }^{2}$ See also Fontana et al. (2018) who estimate the impact of the Nazi occupation in the North of Italy on subsequent support for leftist parties.
} 
at medium and long-term outcomes, and Section 9 concludes. The online Appendix provides additional robustness checks and results.

\section{Historical Background}

In this section, we trace the historical roots of Fascism in Italy. We start by describing how Italy entered World War I, and the postwar political crisis. We then discuss how the Socialist Party became the beneficiary of this political crisis and describe the riots and rural and industrial strikes during this era, sometimes referred to as the "red biennium", and the "red scare" that these created. We finally discuss the origins of the Fascist movement and its seizure of power.

\subsection{Italy and the Great War}

Italy joined WWI one year after the rest of Europe against its former allies Germany and Austria. Although there was strong opposition to the war both within the population at large and in the parliament, the "interventionist" coalition succeeded in engineering the country's entry into the war, and the nationalist propaganda spearheaded by Mussolini and the newspaper he headed played a crucial role in this process.

At the start of the war, the Italian government, despite its alliance with Germany and Austria, declared that it would remain neutral, perhaps because it was lagging behind the rest of Europe in terms of armament and army organization. Its army did not have a very successful record, including in the first Italo-Ethiopian war of 1895-96. Politicians and high-ranking military officials were doubtful about the discipline and preparedness of the troops (Ceva, 1999). Moreover, many believed that an alliance with Germany and Austria would have precluded the recapture of Italian territories still under Austrian control and thus prevent the completion of Italy's unification that had started in 1861 (Ragionieri, 1976b, pp.1962-1965). Consequently, the majority of the members of parliament, including the Socialists, the Catholics (the Popular Party) and most of the Liberals, were "neutralists", meaning that they were opposed to the war and in favor of remaining neutral.

One of the most prominent neutralists was Giovanni Giolitti, the leader of the Liberals and former prime minister. His position, shared by a large part of the neutralists, was to get territorial concessions from the Anglo-French alliance in exchange for Italian neutrality. The confidential government survey, 'On Public Morale', found that the majority of the population, especially in the countryside, was strongly opposed to the war (Bianchi, 2014).

The interventionist movement gained further momentum after the beginning of the war, however. A diverse coalition comprising nationalist conservatives, liberal radicals, republicans, democratic socialists and revolutionary syndicalists, carried out a campaign of nationalist propaganda, joined also by one of the most prominent newspaper, Corriere Della Sera. As summarized by Ragionieri (1976b, p.1975): 
"For these 'storming groups', the war became the historical opportunity to demonstrate the separation from the recent [Giolitti's] past characterized by indecisiveness; it became the opportunity to affirm a different Italy, with a different leadership, able to save [the country] from its 'moral crisis' [...]."

Throughout this process, Mussolini carried out an incessant propaganda campaign for joining the war. Before WWI, Mussolini was a young combative socialist and one of the leaders of the revolutionary wing of the Socialist Party. In 1913 he became editor of the official Socialist newspaper, Avanti (De Felice, 1965, p. 135). When Austria and Germany were on the verge of declaring war, Mussolini wrote an opinion piece, entitled 'Down with the War!', where he suggested that the Italian government should maintain its "absolute neutrality" and help bring the conflict to an end (De Felice, 1965, p. 222). This became the official position of the Socialist Party (Tasca, 1938, p. 8). However, few months into WWI Mussolini changed his tune, and while still writing for Avanti, he started arguing for the war, collected donations for his own interventionist newspaper, Il Popolo d'Italia, and was subsequently expelled from the Socialist Party (Tasca, 1938, p. 7).

Months of interventionist propaganda culminated in demonstrations in Spring 1915, which convinced

the government and the king to secretly join the war against Austria and Germany. Even though the majority in parliament was still against the war, the government signed, without parliamentary approval, the secret Pact of London on April 26th 1915, committing the country to enter the war against the Austro-Hungarian Empire within a month. In exchange, Italy was promised significant territorial compensations (Tasca, 1938, p. 7). One month after signing the Pact of London, on May 24th 1915, Prime Minister Salandra, with the support of the King, declared war on Austria.

\subsection{Italian Socialism and the Red Scare}

The main winner from the postwar political crisis was the Socialist Party, partly because of its consistent anti-war stance. This not only led to a significant vote increase for the party in the 1919 elections, but also generated a red scare, especially as strikes paralyzed the country in 1919-20 and the Socialist Party started calling for a Bolshevik-style revolution in Italy.

The Socialist Party, founded in 1892, was a diverse coalition. While its stronghold was the industrial working class of the Northwestern "industrial triangle", covering the area between Turin, Milan and Genoa, the party also had a strong following in rural areas, especially in the Po valley and in the southern regions of Apulia and Sicily. Pareto (1974, p. 71) describes the situation as follows: "In Italy there are two types of socialism one of which, the rural socialism is indigenous, while the other, the industrial socialism is only the reflection of the French, and, even more, German ideas".

Equally important was the division between the more moderate social democratic and the revolutionary wings of the party. The majority of the membership of the Socialist Party came from the labor unions, especially the CGL (General Confederation of Labor), and local work cooperatives. By 1912, the CGL 
had about 640,000 members, 353,000 industrial workers and 290,000 rural workers locally organized in leagues and work chambers, while the cooperatives of work and production had more than 800,000 members (Schiavi, 1914, p. 421, 426). All the way up to WWI, social democrats controlled the leadership of the unions and, largely as a result of this, held the upper hand in the party. This changed as WWI was drawing to a close.

The end of the war only increased the popular discontent and also coincided with the severe economic recession. Gerwarth described the situation as: "In many ways [Italy's] post-war experience [...] resembled that of the defeated empires of eastern and central Europe more closely than that of France and Britain" (Gerwarth, 2016, p. 6). In fact, contrary to what happened in Paris and London, no parade was organised and the victory was not officially celebrated for two years. This was partly because Italian expectations for territorial gains were dashed. The poet Gabriele d'Annunzio, who in September 1919 headed a small group of troops to invade the town of Fiume, disputed between Italy and Yugoslavia, coined the term Vittoria Mutilata (Mutilated Victory) to describe the situation. The discontent turned into a groundswell of support for the Socialist Party, making it capture the largest share of votes in the 1919 elections.

In April 1919 the Socialist Party led a general strike demanding the full and rapid demobilization of the army. The unrest that had started in the North quickly spread to the South, triggering a series of rural strikes and land encroachments: "at a rhythm marked by the gradual demobilization of the army: in the North massive rural strikes of waged laborers extended for the first time to sharecroppers of the Central Italy; land encroachment by waged rural workers and farmers in Lazio and in the Southern regions was led by unions in the first [region] while spontaneous or led by the ex-combatants movement in the rest." (Ragionieri, 1976b, p. 2070). As support for Socialists grew, the CGL reached more than two million members in 1919. The membership of rural unions which had previously been around 125,000 rose to 760,000 , while labor unions in the steel sector saw their membership surge from 16,000 to 300,000 (Ragionieri, 1976b, p. 2071).

Amid the social unrest, the fear of revolution started mounting. During its 1918 Congress, the revolutionary wing of Socialists took control of the party. Their program centered on "to do as in Russia". A year later the party joined the Communist International (Tasca, 1938, p.13-14), with the new statute explicit stipulating: "The violent conquest of political power on behalf of the workers will signify the passing of power from the bourgeois class to the proletarian class, thus establishing [...] the dictatorship of all of the proletariat." (Payne, 1996, p. 89)

The 1919 elections were a major victory for Socialists and Catholics, the two main anti-war parties. The Socialist Party became the largest one in parliament, doubling its vote share to $32.3 \%$ of the votes and trebling its representation in parliament (Ufficio Centrale di Statistica, 1920, p. LV). The interventionist parties suffered a resounding defeat. A contemporary analyst observed: "The Italian elections, have clearly resulted in the condemnation of the war, with the concentration of an immense multitude of votes on the socialists that have always opposed it and then on the populars [Catholics] to whom no one can attribute 
the responsibility [of the war], and furthermore with the very large abstentionism of voters that did not yet decided in favour of one of the other of the above mentioned [parties], but firm in their resolution of not approving the 'great achievement' withholding their support to the liberals [...]" (Volpi, 1919, pp. 237-8).

The red biennium of 1919 and 1920 witnessed further intensification of Socialist mobilization. Strikes and riots became more widespread, reaching their pinnacle in September 1920 when workers occupied factories all over the country in a move that could have led to a socialist revolution in Italy. Social conflict in rural areas was equally widespread. Socialist rural unions organized the workers and started planning for systemic land collectivization (De Felice, 1965, pp.613-615). In the local elections that took place between September and November 1920, the Socialist Party won a large number of municipalities (more than 2800 out of 8000), especially in rural areas. The growing organization and influence of the Socialist Party in rural areas came to be viewed as an existential threat by landowners.

\subsection{The Rise of the Fascist Party}

In March 1919 Mussolini founded the Fasci di Combattimento. His explicit aim was to restore the "spirit of May 1915", when nationalist demonstrations in the largest cities had pushed the government to enter the war. The movement did not have a clear electoral program, but assembled around the nationalist rhetoric of the "mutilated victory". Early on, the movement concentrated in urban areas and appealed more to the interventionists of 1915 than to war veterans. It attracted revolutionary syndicalists, members of the elite shock troops and a ragtag of nationalists as well as futurist intellectuals (De Felice, 1965).

The initial program of the Fascist movement was heavily influenced by the revolutionary syndicalism and socialist ideas. Nevertheless, its pro-war stance made an alliance with the Socialist Party impossible. The rift between the two movements grew on April 15, 1919, when Fascist army officials and former shocktroop soldiers assaulted the building of Avanti and killed three Socialists. This was the beginning of Fascist violence against Socialists that came to define the early 1920s.

The 1919 elections were disastrous for the Fascist Party, which failed to get any seats in parliament. Mussolini had been unable to form a coalition with other interventionist forces and the party's electoral program was still ill-defined. Two days after the elections, Mussolini and his main collaborators were arrested for the armed assault on a group of Socialists celebrating their electoral victory, but following the then-prime minister Nitti's request, Mussolini was released the day after.

In the months following the 1919 elections, the Fascist movement was in crisis. As reported by (De Felice, 1965, p. 581):

"The first consequences of the electoral defeat were material. Already before the elections the [newspaper] Popolo d'Italia did not have large resources. [...] The resounding electoral defeat was an almost fatal blow: the newspaper sales collapsed and the funds dried up. [...] Not only the newspaper but all the fascist movement and the fascist leadership was under pressure. 
In a few weeks almost all the local branches were disbanded or became inactive; most of the members left for other parties or movements or, discouraged, retired from politics." (De Felice, 1965, p. 587).

Yet, Mussolini soon managed to refashion the party as a robust anti-socialist movement. As described by De Felice (1965, pp. 590-592): "Following the electoral defeat, many Fasci lost most of their initial members [...]; in 1920, their place was taken by new members of different social and political background, who saw in the fascist movement an instrument of anti-socialist and anti-workers action. With the different attitude of the elites, the fist support and donations started to flow, and the reciprocation followed." The party soon gained a reputation for violent action against Socialists (Tasca, 1938). ${ }^{3}$ As put by Lyttelton (2003, p. 43): "the novelty of Fascism lays in the military organization of a political party", and this recipe, with the support of the traditional right, became the basis of Fascist success after 1920.

At this point, the Italian state was fairly weak and unable to control or mediate conflict in the cities or the countryside. In this environment, anti-socialist violence in the cities was coupled with "agrarian fascism" in rural areas. De Felice (1966, p. 3) emphasizes three aspects of this Fascist remaking: "the inclusion of fascism in the mainstream politics; the rise and the rapid spread of the agrarian fascism in the agrarian zones of the Po valley and especially in Emilia; the rapid building up of a unified reactionary-conservative front of the agrarian, commercial and industrial bourgeoisie [...] attempting a rescue that the government seemed unable - or unwilling - to pursue." The expansion of agrarian fascism in the countryside was probably the most important component of this transformation.

The spread of agrarian fascism was made possible by the support of farmers and landowners. They opposed demands for higher wages for day laborers, higher shares of revenue, lower costs and guaranteed income for sharecroppers, and better and more sanitary working conditions for both types of workers, spearheaded by Socialists across the country: "The expansion of Fascism in the rural areas was stimulated and directed by the reaction of the farmers and landowners against the peasants leagues of both Socialists and Catholics. In provinces such as Alessandria, Pavia, or Arezzo, where no Fascist movement existed until late 1920, the agrarian associations were directly responsible for its formation" (Lyttelton, 2003, p. 70). In Lupo's (2005, p.75) summary: “ the earliest fascist centres, urban and petty bourgeois, still linked at their leftist origins, were substituted by right-wing elements, paid by the agrarians or subordinate to them anyway, coming from the countryside where the class struggle was more violent." 4

\footnotetext{
${ }^{3}$ De Felice describes the new anti-Socialist character of the movement with the following example: "The Mantua Fascio was funded on 14 April 1920 [and] so they wrote to the central committee: 'We are well positioned; we got the support of the most prominent men in town [...].' [On 19 April] Flores, the chief of staff to the PM, sent a cable to the PM Nitti saying that in the previous days a retired army general went in various towns of the Monza district [Milan province] offering to industrialist on behalf of the Fasci di Combattimento the protection of squads formed by ex-shock troops in case of strikes and riots. The offer was followed by the request of donations which was largely accepted by the industrialist who gave thousands of Lire." (De Felice, 1965, pp. 590-592)"

${ }^{4}$ Lupo's opinion on the distinction between urban fascism and agrarian fascism is more nuanced: "In my opinion in the case of Ferrara [and in other cases] it does not seem so clear, as in the traditional historiographic representation, the discontinuity between a
} 
Fascist organizations were extremely violent, and used "punitive expeditions" against worker organizations and Socialists in order to restore the control of landowners in the countryside. These anti-socialist actions gained the approval and support of many conservatives, especially because of the perceived impasse created by Prime Minister Giolitti's policy of neutrality in labor disputes, which was thought to have strengthened workers' organizations and Socialists (De Felice, 1966).

The punitive expedition soon became the method of choice for Fascists to expand across the country. Rich landowners, army officials, rentiers and professionals in urban areas represented the leadership of the first armed Fascist squads. These squads were organized in the cities and then directed to the surrounding countryside. Armed by the local agrarian association or supplied from the local military depot of the army, the Fascist black shirts attacked, intimidated and killed workers, laborers and Socialists who were agitating and organizing (Tasca, 1938, p. 102-3).

Agrarian fascism would not have been possible without the complicity of the Italian state. A turning point came following the Socialist victory in the local elections in Bologna in November 1920, when Fascists provoked violence, killed ten Socialists and induced the government prefect to dissolve the council and install a government commissioner. These events then formed a template for Fascists, who started to systematically attack local councils held by the Socialists (and sometimes by the Popular Party). The aim was to force them to resign or create chaos and instability, forcing the government prefect to dissolve the council. Following the Bologna incident, local fascist thugs became the repressive means of the agrarian landowners.

De Felice (1965, pp. 657-658) describes the fast spread of the agrarian fascism as follows. "After the tragedy of Bologna the agrarians move up, gather together and organize themselves. [...] The countryside is now awake precisely in a most favourable time for a conservative movement. The old landowning class often absentee, apathetic and fearful - thought that the socialist unrest of 1919-1920 were the beginning of a Russian-style expropriation.[...] In a few weeks the Po valley was full of more and more Fasci, becoming more and more aggressive. The fascism as a mass movement was starting and, given its origin could not be anything else than a 'white guard' [counter-revolutionary movement as in Russia]."5

leftist urban fascism [...] and a right-wing agrarian fascism [...]. In 1920-22 Ferrara there is on the contrary a convergence between fascists, liberal conservative groups and the Agrarian association" (Lupo, 2005, p.78).

${ }^{5}$ Many perfects reported key support for the Fascist Party from local agrarian associations. For example, the prefect of Pavia on 28 February 2021 wrote: “... the fascist movement in this province, supported and urged by the landed class is directed by two young ex soldiers that found in the movement their source of revenue being both of them paid for the role of president and secretary. The steering committee is formed by an accountant and four landowners from the province.[...] It is in constant contact with the Central committee in Milan [...] and in close relationship with the Agrarian Association of Pavia which provide large financial support receiving in exchange protection in case of peasants' strikes”. The prefect of Vicenza reported on 4 April 1921: “... the Agrarian Fasci or Fasci of Social Defense have been established by landowners and managers of rural estates with the aim of fighting against the local peasants leagues [... So far, the local fasci di combattimento are not well funded [...]. On the contrary, the agrarian fasci are much better funded because the landowners and managers agreed to fund the organizations [...]." On 29 March 1921 the Rome prefect reported that "in Montefiascone on 13 March 1921 the local section of the Fasci was established with 220 members [...] and it was mainly established by local landowners, in anticipation of a potential peasant strike, in order to counteract potential violence from the peasants. There are similar reports from other prefects. 
The success of agrarian fascism was critical for the movement's national prominence. On the back of rural support, the Fascist Party soon became one of the largest in the country and came to control large areas, especially in the countryside, many of which had previously been Socialist strongholds.

Another turning point, and the inevitable recognition of the Fascist Party's increasing de facto power, came when the liberal government that had come to power in June 1920, led by Giolitti, included it in the National Blocks for the general election in 1921. Giolitti had called the elections earlier in 1921 in an attempt to exploit the apparent weakness of Socialists, which had been battered by incessant Fascist violence and was disorganized because of its left-wing's split to form the Communist Party in the January 1921 Livorno Congress. Giolitti's calculus was to build a unified conservative, nationalist, liberal and democratic coalition, including the Fascists, to defeat the 'Bolshevik' forces.

The elections took place in a climate of widespread violence, mostly perpetrated by the Fascists, which resulted in dozens of deaths all over the country. There was no clear majority in the voting booth, however: "The outcome of the elections was clearly contrary to Giolitti's expectations. The Socialist Party lost 34 seats (fewer than 300,000 votes) but kept 122 seats, much more than Giolitti [expected]; furthermore the communists gained 16 seats. The Popular Party not only did not decline, but moved from 100 to 107 seats. The National Blocks gained 275 seats, but it was an heterogeneous mass of MPs, most of whom were not supporting Giolitti. 45 newly elected MPs in the lists of the National Blocks were fascists and nationalists" (De Felice, 1966, p.92). Unable to form a majority government, Giolitti resigned in July 1921.

The ensuing instability created an ideal environment for Mussolini to intensify street violence and ultimately take control of the government. Despite a number of challenges to Mussolini's leadership between the 1921 elections and the Spring 1922, the Fascist Party had been growing in numbers and intensifying the systematic violence towards its enemies.

In late October 1922, Mussolini organized a march on Rome, which gathered about 25,000 black shirts. The then-Prime Minister Luigi Facta wanted to send the troops to stop them, but King Victor Emmanuel III did not agree and Facta resigned. On 29 October 1922, the King asked Mussolini to form a new government, to assemble a right-wing coalition, including Liberal, Democratic and Catholic ministers.

Once he took the reins of government, Mussolini had no intention of giving them up. In the first months, Mussolini consolidated his grip on power, in particular by incorporating Fascist paramilitary organizations into the state apparatus and dissolving all remaining Socialist local councils. ${ }^{6}$

Although prime minister, Mussolini still faced a largely anti-fascist parliament, elected in 1921. Mussolini engineered a new electoral law, Legge Acerbo, to facilitate his complete takeover of government. The law was approved in 1923 with the support of many Catholic members of parliament who went against their leadership's opposition to the law. By instituting a strongly majoritarian electoral system, the law facilitated

\footnotetext{
${ }^{6}$ One of the first measures of the Mussolini's government was an amnesty for political violence "when the act has been committed for a national interest" (R.D. 22/12/1922 n. 1641 art. 1) which benefited only the Fascists arrested for the violences committed in the previous years.
} 
the consolidation of most right-wing support in Fascist hands. In Spring 1924, Mussolini dissolved the parliament and called new elections where Fascist lists won more than $65 \%$ of the national vote.

The oppositions approached the elections divided and weak, battered by years of Fascist violence and deprived by the control of local councils. They considered boycotting the election until few weeks before the vote, pointing out the "arbitrariness and the open violation of the constitutional law" by the government (De Felice, 1966, p. 467). The aim of Mussolini was to "incorporate in his 'governmental' list the largest part of the liberal forces and isolate with any means the elements that rejected his policy and promoted an uncompromising opposition" (De Felice, 1966, pp. 569-70). But this also meant that he wanted to limit street violence and prove that Fascism could bring order. Violence during the electoral campaign did not disappear completely, and there may have been as many as "hundreds of wounded and several dead" in the hands of the Fascists (De Felice, 1966, p. 584).

This meant that some amount of intimidation and interference did take place in the elections, but there is no consensus on how much. There was no centralized attempt to rig the election or coordinate violence; the local conditions and strength of the Fascist and the opposition parties were the key determinant of the outcome (see on this Ragionieri, 1976, pp. 2138-9; De Felice, 1966, pp. 588-92; Lupo2005, pp. 186-7, among others). ${ }^{7}$ Episodes of intimidation, violence and vote rigging were denounced at the opening of the new parliament by Giacomo Matteotti, the leader of the Social Democratic Party. Ten days later Matteotti was kidnapped and killed. The murder provoked a political and constitutional crisis resulting eventually in the establishment of the Fascist dictatorship. Mussolini himself, who felt unable to provide unified approach the party, impatiently exclaimed at the eve of the elections "This is the last time that we run the elections in this way. Next time I'll vote for everyone” (De Felice, 1966, p. 584). Mussolini soon banned local council elections and set up a single party system, outlawing all other political movements. From 1938 onwards, elections were entirely abolished.

\section{Data}

Our database covers 5,775 municipalities in 1921 from 64 provinces (out of the 69 existing in 1919). ${ }^{8}$ Data for other periods, which are at times more disaggregated, are mapped to the 1921 municipalities.

\subsection{Electoral Data}

The official municipality-level data on the three national elections of 1919, 1921 and 1924 have gone missing from the parliamentary archives. The most complete existing collection of these data was undertaken by

\footnotetext{
${ }^{7}$ There was also violence after the elections, for example, in the Monza district, where the Popular Party scored a major success and the Fascist list obtained only $16 \%$ of the votes.

${ }^{8}$ In 1921 there were 8355 municipalities in Italy, excluding the recent annexation of Julian Venetia and Trentino. We managed to recover the election data for 5775 municipalities in the 1919-1924 elections, which represent our sample.
} 
Corbetta and Piretti (2009), but contained data for all three elections for only about 2,000 municipalities. We expanded the coverage of these data for all three elections, using local and national historical newspapers and local state archives for almost 6,000 Italian municipalities. We examined about 1,200 different newspaper for each of the three elections considered. Electoral results for municipalities in the local electoral district were typically reported in one of the editions of local newspapers following the day of the elections. The format varied substantially from well documented tables, like the one in Figure A1 in the Appendix, to more hidden articles discussing electoral results. When local newspapers did not cover all municipalities, we visited the local state archives, browsing historical documents for the period considered. In several instances, we found useful information in the form of hand-written tables summarizing local results, annotations by electoral authorities, or telegraphic communications from local to central electoral offices (see Figure A2 in the Appendix).

Historical electoral data cover most of Italy, with the exception of few areas, notably in Calabria and Sicily, for which even local newspapers or state archives did not contain any useful information.

Electoral data for the period 1946-2018 are sourced from the official electoral statistics of the Italian Ministry of Internal Affairs. ${ }^{9}$

\subsection{Data on Fascist Activity}

From the compiled historical electoral data, we derived several measures of local support for Fascism: the Fascist vote share in 1919, the Fascist vote share in 1921, and the Fascist vote share in 1924. In 1919 the Fascists were presenting candidates only in a few electoral districts, in 1921 they were (with few exceptions) part of the National Blocks alliance together with several conservative and moderate parties. The presence of this block makes it challenging to measure the local Fascist support in 1921. Our preferred measure for the local support to Fascism is therefore the Fascist vote share in 1924, which includes all electoral lists which explicitly referred to and supported Fascism. Figure 1(a) depicts the Fascist vote share in 1924 across Italy. We also derived several measures of support for Socialism: the Socialist vote share in 1919, the Socialist vote share in 1921, and the Socialist vote share in 1924. Figure 1(b) depicts the Socialist support in 1919. The Socialist vote share in 1913 is from Corbetta and Piretti (2009).

We collected two alternative measures of the local presence of Fascism. Franzinelli (2003) records 2,566 episodes of political violence, of which 2,123 were Fascist actions, leading up to the March on Rome at the end of October 1922. They include 727 killings by Fascists. Using these data, we created a municipality level measure of Fascist violence in 1920-2 which records the number of violent episodes per 1000 inhabitants for the period 1920-2. From the same source we created three alternative measures of violence as well, which we use in our robustness checks: Fascist killings in 1920-2, focusing on killings only, Political violence in 1920-2, including all political violence, and Non-Fascist Violence in 1920-2, which excludes

\footnotetext{
${ }^{9}$ https://elezionistorico.interno.gov.it
} 
Fascist violence. Secondly, we collected information on local branches of the Fascist Party in September 1921 from the prefect reports located in state archives throughout Italy. Finally, we constructed a dummy for the presence of large donors to the Fascist Party in the period 1919-1925 (Large donor dummy (1919-25)) from the detailed information provided in Padulo (2010), which we also use in the Appendix.

\subsection{Deportation of Jews}

We created two measures of the deportation of Jews from Italian municipalities using the data provided by the Contemporary Jewish Documentation Centre (CDEC). ${ }^{10}$ These are: a dummy for any Jews being deported in 1943-45, and an estimate of the number of Jews deported divided by the 1911 Jewish population. Since Jewish population is available only at the district level and for the district capital, we apportion noncapital district Jewish population across municipalities according to their total population and cap the Jews deportation ratio at one.

\subsection{WWI Casualties}

There are varying estimates of the number of Italian soldiers who died during WWI — ranging from 510,000 to 600,000 . We use the military Roll of Honor, which provides information about 529,028 members of the armed forces who died during the war (name, dates of birth and death, places of birth and death, regiment, force, rank). The data have been digitized by the Institute for the History of the Resistance and the Contemporary Society (ISTORECO). ${ }^{11}$ We focus on footsoldier casualties (representing three quarters of all casualties), since they are less likely to suffer from selection. ${ }^{12}$

Our main instrument, Share of footsoldier casualties, is the number of casualties among footsoldiers originating from a municipality divided by male population over the age of six in the 1911 Italian Census. In Figure 1(c) we show the distribution of WWI casualties among footsoldiers.

The rich information contained in the Roll of Honor allows us to create a set of regiment dummies to control for the effects of the war experience in a specific theatre of war. We additionally identified municipalities which had casualties among special assault corps, among volunteers, and in the most bloody battles of the war (defined as days for which more than 1,000 casualties occurred).

Our data on veterans is constructed by subtracting casualties from drafted soldiers, which are sourced from official military statistics (Ministero della Guerra, 1927). For each military district we subtracted casualties by cohort and obtained a measure of returning soldiers over the male population above the age of six, assigning the same value to all municipalities within each military district. We created two additional variables from the same data: one for the veteran cohorts 1874-95 another for the cohorts 1895-1900. The

\footnotetext{
${ }^{10}$ www.cdec.it/i-nomi-della-shoah

${ }^{11}$ www.albimemoria-istoreco.re.it

${ }^{12}$ Special corps from the navy or the air force are more likely to recruit from specific geographic locations and from specific demographic groups.
} 
first variable includes the veterans who were demobilized before the 1919 elections and therefore could vote in those elections, while the second includes all the veterans who continued to serve until 1920-1921 and could not vote in the 1919 elections.

Finally, the data on the location of WWI monuments in 1921 are collected from the official catalogue of the Italian Ministry for Cultural Heritage. ${ }^{13}$ We created two measures: a dummy for the presence of a WWI monument by 1921, and the number of WWI monuments per 1000 inhabitants by 1921 .

\subsection{Other Data}

As alternative sources of variation, we constructed estimates of Excess mortality in 1918 (relative to preWWI mortality for the years 1911-1914) as a measure of the effect of the Spanish flu, which was responsible for the large increase of deaths in 1918 in Italy. We construct this measure using information on the number of deaths at municipality level provided for the years 1911-1914 and 1918 by Direzione Generale della Statistica e del Lavoro (1917-1924). These data are available only for a much smaller sample of 207 urban municipalities.

We also constructed estimates of the severity of droughts during this period. There were no nation-wide droughts, but there were localized droughts during the 1919 agricultural season. We therefore constructed a measure of Relative rainfall in winter-spring 1918-9 using data from 427 weather stations, which we gather from the Hydrographic Bulletins (1915-1979) for the 16 Italian hydrographic compartments. ${ }^{14}$ Relative rainfall is measured at the weather station level (aggregating rainfall from December 1918 to May 1919), using the average for the winter-spring months for the years 1915-1979 as denominator, and then interpolated at the municipality level using the inverse of the distances as weights with a cutoff of $30 \mathrm{~km}$. The relative rainfall measure is then capped at one, so that we only exploit shortfalls of rain relative to its long-term average (see Figure A3 in the Appendix for the geographic distribution of relative rainfall).

We additionally collected data on a large set of controls. Geographic variables (municipality (log) area, elevation of the main centre, and maximum elevation), and demographic variables, including total population, the share of population below the age of six, the share of day laborers, the share of sharecroppers, the share of elites (entrepreneurs and rentiers), the share of bourgeoisie (defined as professional, white collars, and shopkeepers), and the literacy rate come from the official Italian Census (1911, 1921, 1931). Data on day labourers, share croppers, elites, and bourgeoisie are available for more than 700 agrarian zone in the census, each comprising several municipalities. We assume the same occupational shares across all municipalities within each agrarian zone. The share of industrial workers, and the number of per capita industrial firms are sourced from the 1911 Industrial Census.

Using the information reported in Direzione Generale della Statistica e del Lavoro (1912), we created a

\footnotetext{
${ }^{13}$ www.catalogo.beniculturali.it

${ }^{14}$ The Hydrographic Bulletins are available at http://www.acq.isprambiente.it/annalipdf/.
} 
dummy for municipalities with at least one landowner association, typically set up to deal with local agrarian workers.

Data on the number of agrarian strikes in 1920 are gathered from the 1921 Labor Bulletin (Ministero per il Lavoro e la Previdenza Sociale, 1921). Data for the strikes and strikers in both industry and agricolture in 1913-14 are from the Labor Bulletins for 1913 and 1914 (Ministero per il Lavoro e la Previdenza Sociale, 1914). Data on violent crimes and crime rates in 1874 are collected at the level of the 1813 preture in the statistics published by the Ministry of Justice (Ministero di Grazia e Giustizia e dei Culti, 1875). ${ }^{15}$ Finally, dummies for the prevalence of large landholding (Large Landholding in 1885) and widespread landownership (Landownership in 1885) come from the 1882-1885 Parliamentary inquest (Jacini, 1885).

The summary statistics for the main variables used in the analysis are reported in Table A1 in the Appendix.

\section{WWI Casualties and Support for the Socialist Party}

In this section, we document the relationship between WWI casualties and support for Socialists, which will be our first stage when investigating the impact of the threat of socialism on the rise of fascism. As explained in Section 2, the disruption, hardship and disillusionment created by the war were among the major factors leading to a surge in the Socialist vote share in the 1919 election. Our purpose in this section is to document this relationship across Italian municipalities. As explained in Section 3, we focus on an estimate of footsoldier casualty for this purpose, which excludes the casualties among specialized troops, such as the arditi. Footsoldier casualties, which make up over $80 \%$ of all WWI deaths, are less likely to suffer from "selection" (which would occur if a higher fraction of troops in some regiments came from a given area with greater commitment to the war) and are more directly related to the reaction of ordinary Italians towards the war than among professional or highly-trained elite fighters.

Our estimating equation can be summarized as:

$$
\text { Socialist } \text { Share }_{i}^{1919}=\gamma \cdot \text { Foot Soldier Casualty }{ }_{i}+X_{i}^{\prime} \beta+\varepsilon_{i}^{\text {firststage }},
$$

where Socialist Share ${ }_{i}^{1919}$ is the vote share of the Socialist Party in municipality $i$ in the 1919 election, and Footsoldier Casualty $i$ denotes our estimate of footsoldier casualty in the municipality (relative to male population over the age of six). In addition, $X_{i}$ is a vector of covariates, which includes the vote share of the Socialist Party in the 1913 election, various geographic, agricultural and military controls. It also separately includes the share of veterans in the municipality population from the birth cohorts 1874-95, who made up about $65 \%$ of all soldiers, were demobilized earlier and could vote in the 1919 elections, and the share of

\footnotetext{
${ }^{15}$ Unfortunately these detailed statistics have been discontinued after 1875 .
} 
veterans from the birth cohorts 1896-1900, who were demobilized in 1920-21, could not vote in $1919,{ }^{16}$ and missed some of the more harrowing parts of the war.

Finally, $\varepsilon_{i}^{\text {firststage }}$ is a random error term, capturing all omitted factors, which we allow to be heteroscedastic and correlated across municipalities; in practice, the standard errors we report are clustered at district level. ${ }^{17}$

Equation (1) is not just interesting in and of itself, but will also be our first stage when estimating the impact of the threat of socialism on the rise of the Fascist Party.

The estimates of equation (1) are presented in Table 1. The first column is our most parsimonious specification and includes only the regiment fixed effects, which are dummies for any deaths from the municipality in a specific regiment and control for other factors that impact soldiers serving in different regiments and theaters of war. These dummies are included in all of our specifications; province fixed effects, which ensure that our results are not driven from the comparison of different provinces and are also included in all of our specifications; and basic demographic controls (in particular, a quartic in log municipality population and the fraction of the population younger than six in 1911). The footsoldier casualties variable has a coefficient of 2.034 with a standard error of 0.315 (and is thus significant at less than 1\%). This coefficient estimate implies that a one standard deviation increase in footsoldier casualties in the population (which is 0.016 of the male population over six years old in 1911) is associated with an increase of 3.3 percentage points in the 1919 Socialist vote share in the municipality (relative to a mean of 0.316 and a standard deviation of 0.271). Put differently, this estimate implies that if all footsoldier casualties had been zero, the Socialist vote share in 1919 would have been lower by 6.5 percentage points (more than a fifth of all socialist votes in 1919).

The rest of the table shows that this relationship is robust when a range of other covariates are included. In column 2, we include additional geographic controls (in particular, log area, elevation of the main municipality center and maximum elevation, which proxies for ruggedness of the terrain). The inclusion of these additional controls has hardly any effect on our coefficient estimate. In column 3 , we add the Socialist vote share in the municipality in the 1913 elections, which controls for permanent differences in political attitudes in the municipality. This reduces the coefficient slightly to 1.772 , which also becomes a little more precise (standard error $=0.236$ ) and thus remains significant at less than $1 \%$. Column 4 additionally includes a range of military controls: our veterans variables as well as dummies for any of the deaths in the municipality coming from special assault soldiers, or from volunteers, or having taken place in the most high-mortality battles. These controls have no discernible impact on the coefficient estimate for the share of footsoldier casualties. The veteran variables themselves are significant, but with opposite signs: the share of veterans from older cohorts is positive, while the share of veterans from younger cohorts is strongly neg-

\footnotetext{
${ }^{16}$ Active soldiers, numbering almost 900,000 according to Ufficio Centrale di Statistica (1920, p. XXVI), did not have the right to vote in 1919.

${ }^{17}$ Each of the 5775 municipalities belongs to one of the 181 administrative districts.

We also calculated spatially-corrected standard errors in the Appendix (Table A2). We opted for the district-clustered standard errors in the text, because they tend to be more conservative for the 2SLS estimates and very similar for the first stage.
} 
ative. We interpret this as evidence that older veterans, who suffered more during the war and may have benefited from the Socialist campaign for early demobilization, as well as perhaps their families, were more likely to vote Socialist. In contrast, younger veterans, who did not benefit from early demobilization, were still under arms and not allowed to vote, may not have had the same favorable attitudes towards the Socialist Party, and their families might have been less inclined to vote Socialist.

Finally, columns 5 and 6, add additional agricultural and urban controls, with very little effect on our estimate of the share of footsoldier casualties. ${ }^{18}$ Since the coefficient estimates in these columns is about $15 \%$ smaller than the coefficient estimate in column 1, the implied quantitative magnitudes are about $15 \%$ smaller than those discussed above.

Panel A of Figure 2 shows a bin scatterplot of the first-stage relationship, focusing on our most demanding specification from column 6. It visually illustrates the range of variation and shows that the linear model is a good fit to data.

Our overall interpretation of the results in Table 1 is that war casualties had a first-order impact on local support for the Socialist Party. We should also add at this point that we do not view this estimate to capture all of the effects of the war on Socialist support. Many of the hardships and discontent caused by the war were common across municipalities and would thus not be captured by the share of footsoldier mortality, and hence the quantitative estimate - that without any casualties the Socialist vote share would have been lower by 6.5 percentage points - is likely smaller than the total impact of the war on Socialist support. All the same, the strong effect of the footsoldier casualty variable already indicates that the disruption caused by the war did intensify the support for Socialists.

The patterns shown in Table 1 are highly robust. In Appendix Table A3, we construct various alternative instruments, for example, focusing on casualties among reservists and drafted footsoldiers, casualties only among drafted soldiers or all casualties, and show that the results are very similar. Additional robustness results will be discussed in the context of our instrumental-variables (IV) estimates in the next section.

One concern with our footsoldier casualties measure is that, despite our regiment and province fixed effects and other controls, municipalities with different historical or current characteristics could have sent soldiers to systematically different theaters of war or might have experienced differential mortality because of variation in the underlying conditions or motivations of the soldiers. To check against this possibility, which is central both for the interpretation of the impact of war casualties on Socialist support and for our later IV estimates, in Table 2 we investigate the relationship between our footsoldier casualty measure and a battery of pre-1919 economic, social and political characteristics of the municipality.

Specifically, we look at the support for Socialists in 1913, literacy in 1911, violent crimes (as a share of

\footnotetext{
${ }^{18}$ The agricultural controls are the fraction of day laborers, the fraction of sharecroppers, and a dummy for the presence of landowner associations in the municipality. The urban controls are fraction of industrial workers in the male population, the number of industrial firms relative to male population, the literacy rate in 1911, the fraction of entrepreneurs and rentiers, and the fraction of the middle class in the population.
} 
population) in 1874 , crime rate in 1874 , industrial workers as a share of male population as well as industrial firms normalized by male population in 1911, dummies for the prevalence of large landholdings and widespread land ownership in 1885, and various measures of industrial and agricultural strikes or number of strikers in the population in 1913-14. In all cases, we report estimates from the specifications corresponding to columns 4 and 6 from Table 1. The former includes all of our controls except the agricultural and urban ones, while the latter is our most loaded specification. The results in Table 2 are fairly clear: in none of the 24 specifications for the 12 variables we look at do we see a correlation with the share of footsoldier casualties that is close to statistical significance. This pattern bolsters our confidence that our footsoldier casualties measure zeroes in on the random component of WWI casualties and provides an attractive source of variation for investigating the effect of the (perceived) threat of socialism on the rise of fascism in Italy.

\section{Main Results}

In this section we provide our main results on the relationship between the threat of socialism in 1919 and early 1920s and the subsequent rise of the Fascist Party. We start with our main IV models and then investigate their robustness. Additional evidence bolstering our interpretation is provided in the next section and mechanisms are investigated later in Section 6.

\subsection{The Effects of Socialist Vote Share in 1919 on Fascist Vote Share in 1924}

Our main outcome variable for Fascist activity in an area is the vote share of the Fascist Party in 1924. As highlighted above, the 1924 election occurred after the Fascists took control of the government following the March on Rome. This raises questions about electoral fraud and intimidation of voters. Though we have no systematic way of ruling out such concerns, at worst the ability of the local Fascist squads and the party to organize voter fraud is a measure of their strength in the area. Hence, throughout, we interpret the Fascist vote share in 1924 in an inclusive manner, to measure both support among ordinary Italians and the ability of the local party to mobilize and coerce votes.

Our main regression model is

$$
y_{i}^{t}=\alpha \cdot \text { SocialistShare } i_{i}^{1919}+X_{i}^{\prime} \beta_{y}^{I V}+\varepsilon_{i}^{I V}
$$

where $y_{i}^{t}$ is one of our measures of fascist activity in municipality $i$ during time period $t$, here the vote share of the Fascist Party in 1924. The other variables are the same as in equation (1), which will also be the first stage for the two-stage least squares (2SLS) estimates reported in this section.

The exclusion restriction for this empirical strategy relies on two premises. First, the footsoldier casu-

alty variable should be orthogonal (conditional on regiment and province fixed effects) to $\varepsilon_{i}^{I V}$ in (2) and in particular, uncorrelated with municipality characteristics impacting voting patterns. We believe this is plau- 
sible in light of our discussion in Section 2, which suggested that footsoldier casualties were due to random variation in the mortality in different battles and areas. This interpretation is bolstered by the evidence we provided in Table 2 (showing that this variable is uncorrelated with a long list of pre-1919 municipalities characteristics) and the fact that veterans themselves are not more likely to vote for the Fascist Party (see below for more discussion on this). Second, the effects of footsoldier casualties should be fully captured by the vote share of the Socialist Party in the 1919 election. We believe that this is also defensible, since our interpretation throughout is that the Socialist vote share represents the broader red scare and the perceived threat of socialism (for which we provide evidence in Section 6).

The results with Fascist vote share in 1924 are presented in Table 3, which has the same structure as Table 1. Panel A provides the 2SLS estimates, and Panel B shows the OLS estimates for comparison.

In all six columns of Table 3 we see a sizable impact of the Socialist vote share in 1919 on the subsequent electoral support for Fascists. In our most parsimonious specification in column 1 (which only includes regiment, province and demographic controls as in column 1 of Table 1), the coefficient estimate is 0.375 (standard error $=0.162$ ). This magnitude implies that a one standard deviation higher Socialist vote share in 1919 (which is 27.1 percentage points) is associated with a 10.1 percentage point increase in the Fascist Party vote share in 1924 (relative to a mean of $61.9 \%$ and the standard deviation of $25.7 \%$ ). Hence, the surge of the Socialist Party in 1919 accounts for a significant portion the cross-municipality variation in the subsequent local support for Fascists. ${ }^{19}$

The estimates in the remaining columns are fairly stable. Columns 2 and 3 add geographic controls and the Socialist vote share in 1913, but the coefficient changes only a little (to 0.429 in column 2 and to 0.476 in column 3). Column 4 adds the military controls, including the share of veterans in the population from classes 1874-1895 and 1896-1900. As the table shows, this has a small impact on the coefficient of the Socialist vote share (which goes from 0.476 in column 3 to 0.504 and remains statistically significant at less than $1 \%){ }^{20}$

Panel B of Figure 2 depicts our most demanding specification visually using a bin scatterplot and indicates that the relationship is approximately linear.

Panel B of Table 3 shows that the same relationship between the Socialist vote share in 1919 and the Fascist vote share in 1924 is not present in the OLS. This is intuitive. When we focus on the entire source of variation in the Socialist vote share, we are capturing the fact that some places vote for Socialists, over and above what we expect on the basis of their covariates, because they are ideologically closer to Socialists. The persistent component of this unobserved source of ideological heterogeneity across municipalities creates

\footnotetext{
${ }^{19}$ In the same way that our first-stage estimates do not capture the total effects of the war on Socialist support in 1919, these IV estimates do not incorporate the effects of the common component of the red scare on the rise of the Fascist Party.

${ }^{20}$ Consistent with the pattern we saw in Table 1, the coefficient on the share of younger veterans (not shown in the table) is positive in the second stage, suggesting that these cohorts supported the Fascist Party, over and above the channels being captured by our 2SLS estimates. Nevertheless, their inclusion in the regression does not affect our coefficient of interest, because they did not vote in the 1919 elections and this variable is not (conditionally) correlated with our footsoldier casualties variable. The addition of agricultural and urban controls in columns 5 and 6 does not change any of these patterns.
} 
a negative bias in the OLS estimate of the effect of the Socialist vote share on the Fascist vote share in 1924. We therefore interpret the stark difference between the OLS and the IV estimates as confirming the importance of focusing on an exogenous source of variation in the local support for the Socialist Party.

\subsection{Other Measures of Fascist Activity}

Table 4 turns to two other measures of Fascist activity in the municipality. The first, shown in the top two panels of Table 4, is a measure of Fascist violence (squadrismo) between 1920 and 1922, normalized by municipality population. As noted previously, this type of violent, anti-socialist action was a hallmark of the Fascist Party and played an important role in its rise. The second measure, our focus in the next two panels, is the presence of local party branches in 1921. In addition to validating our results using the Fascist vote share in 1924, these two measures are of interest because they capture Fascist activity at the height of the movement's violent campaign against Socialists and also because they are informative about some of the channels via which local Fascist activity might have impacted later support for the party.

Table 4 has an identical structure to Table 3 . The results in this table are uniformly consistent with our hypothesis that the (perceived) red scare, as captured by the Socialist vote share in 1919, has a large and statistically significant effect on local fascist activity. For example, the estimate for Fascist violence in the top panel of Table 4 in our most demanding specification in column 6 is 0.312 (standard error $=0.122$ ), which implies that a one standard deviation in the 1919 Socialist vote share is associated with an increase of 0.085 in the expected number of Fascist violent episodes per thousand inhabitants (relative to a mean of 0.042 and a standard deviation of 0.164). The estimate for the presence of a local Fascist branch in the same specification is 0.672 (standard error $=0.266$ ) and implies a similarly sizable effect: a one standard deviation in the 1919 Socialist vote share is associated with an increase of $18 \%$ in the probability of having a Fascist local branch by the Autumn of 1921 (relative to a mean of $14.5 \%$ and a standard deviation of 35.2\%). In both tables, the estimates are fairly stable across columns, once again increasing our confidence that the instrumented Socialist vote share in 1919 is not capturing some omitted municipality characteristics.

The two panels of Figure 3 illustrate these relationships visually.

One difference between the results in Table 3 and those in Table 4 is that in these models, the OLS estimates are positive as well, but consistent with our interpretation of OLS estimates being biased downwards because of variation in the intensity of Socialist ideology or politics across municipalities, these estimates are much smaller than, about $20 \%$ or so of, the IV estimates.

\subsection{Robustness}

Further robustness checks for the results in this section (and for the first-stage relationship discussed in the previous section) are provided in the Appendix. Briefly, in Table A4 we show that the results are robust to controlling for the Fascist Party's vote share in the 1919 elections (we did not include this variable in 
our baseline models, because Fascists did not field candidates in most constituencies). The results are very similar if the South, where Fascism was initially weaker, is excluded (see Table A5), and when we use an alternative measure of the Fascist vote share in 1924, focusing only on the official Fascist lists (Table A6). Tables A7 and A8 document the robustness of our results to alternative constructions of the footsoldier casualty variable and alternative estimates of local violence. Finally, in Table A9 we replace regiment fixed effects with either front times semester or front times month fixed effects in order to more finely control for other aspects of war experience. ${ }^{21}$

\section{Investigating the Mechanism}

Our interpretation of the relationship between the (instrumented) Socialist vote share in 1919 and the rise of Italian Fascism in the early 1920s is through the perceived threat of socialism. The hardship and disillusionment that the war created strengthened the Socialist Party, whose success in turn encouraged the center-right and perhaps others to fall behind the Fascists who presented themselves as the most robust defense against Socialism. In this section, we provide evidence consistent with this interpretation and against several alternative explanations.

\subsection{Socialist Vote Share and Agrarian Strike Activity}

As a first step in building up the evidence for our mechanism, Table 5 shows that the Socialist vote share in 1919 is strongly correlated with agrarian strikes in 1920. This table has the same structure as our previous tables (with the same six specifications). It shows a consistent pattern of strong correlation between the Socialist vote share in 1919 and agrarian strike activity. The coefficient estimate in the most demanding specification in column 6 shows a coefficient of 0.200 (standard error $=0.071$ ), which is significant at less than $1 \%$ and implies a sizable increase in agrarian strike activity: a one standard deviation greater Socialist vote share is associated with a 0.05 increase in strike activity in the area (relative to a mean of 0.3 and a standard deviation of 0.6 of agrarian strikes).

This association with agrarian strike activity also provides a channel via which local landowners and entrepreneurs, as well as smallholders, could have perceived the threat of socialism - as they saw more strikes happening around them, they would become more concerned about the next step in the mounting support for the Socialist Party.

\subsection{Where Did Fascist Votes Come from?}

An alternative interpretation is that the Socialists and Fascists were competing for the same set of voters, who would then switch from one to another. According to this interpretation, many of those who voted for

\footnotetext{
${ }^{21}$ We know from the Roll of Honor, in which one of the 16 fronts an individual soldier died.
} 
the Socialist Party in 1919 may have switched away from them and towards Fascists in 1924. We tackle this question directly by looking at where the votes for Fascists in the 1924 elections came from. Table 6 shows that they did not come from Socialists. This table, which has an identical structure to our previous ones, shows no significant relationship between the instrumented 1919 vote share and the 1924 vote share of the Socialist Party. If anything, the relationship is positive, though not significant. Thus, these results suggest that there was no systematic subsequent decline of the Socialist Party in the areas where it received additional votes because of the disruptions caused by the WWI. ${ }^{22}$

In Appendix Table A10, we show that Fascist votes came from center-right parties, such as the Nationalists (which disappeared as a party and joined the Fascist Party en masse), the Agrarian Party, and the (Catholic) Popular Party. This evidence bolsters our interpretation that the rise of fascism in Italy was caused by the center-right falling behind Fascists.

\subsection{The Direct Effect of War on Fascist Support}

An alternative interpretation of our results is that the war, and service in the war, may have directly increased support for fascists, who did try to attract veterans and recruited some of them into their movement and whose nationalist and pro-war rhetoric may have appealed to some who served in the trenches. Though this hypothesis is plausible, and our results with the younger cohorts of veterans in Tables 1 give it some credence, overall this channel can neither account for our results nor appears particularly important in practice.

First, the evidence presented so far shows that the impact of veterans on the 1919 elections is more complex than the hypothesis that veterans are more likely to support the Fascist Party. In fact, having more veterans from the older cohorts, which made up about $65 \%$ of all veterans, is associated with greater support for the Socialist Party. Second, we show in Table 7 that municipalities with greater footsoldier casualties show no evidence of more nationalist views or fascist activities before the red biennium. In columns 1-4 of Table 7 we see that the share of footsoldier casualties is unrelated to Fascist and Nationalist vote shares in the 1919 elections, thus arguing against a simple relationship between footsoldier casualties and support for right-wing, pro-war political groups. Even more striking is the evidence in columns 5-8, which indicate that the number or the presence of war monuments, likely symbols of pro-war or nationalist sentiment in the area, are unrelated to footsoldier casualty. This strengthens our interpretation that those who experienced the war firsthand, especially from the earlier cohorts, did not feel particularly positively about the war experience or the nationalist cause.

\footnotetext{
${ }^{22}$ Since the coefficient estimates on the Socialist vote share in 1919 are uniformly positive, but not significant, the estimates are consistent with the additional votes that the Socialist Party received in 1919 having migrated to the Fascist Party. Moreover, even if all of these votes did go to the Fascists, this would have been a small fraction of the additional votes that the Fascists received in 1924. Finally, the fact that Fascist votes did not come at the expense of the Socialists is also consistent with our presumption that the variation in Fascist vote share does not just reflect the success of local Fascists in preventing Socialist supporters from voting.
} 


\subsection{Local Elites and Fascist Activity}

As discussed in Section 2, the historical record suggests that the Fascist movement may have received considerable support from local elites, especially in the rural areas where major landholders and some smallholders were alarmed by agrarian strikes. We investigate this issue further in Table 8, where we look at whether the surge in Socialist vote share in 1919 led to a stronger increase when the elites were better organized. We use two (admittedly imperfect) measures of elite organization: the presence of a landowner association in rural areas, and the share of entrepreneurs and rentiers in the population, which may be more relevant for urban areas. Our focus is the interaction of these variables with the increase in Socialist support in 1919. We present these results in two ways. In Panels A and B, we focus on IV models, where we have two endogenous variables - the Socialist vote share in 1919 and its interaction with the measure of elite organization - and both of those are instrumented, with footsoldier casualties and their interaction with the elite variables. To save space we look at the specifications from columns 4 and 6 (from our baseline table structure in Table 1, for example) and do not show the first stages (just reporting the Kleibergen-Paap Fstatistics). The instrument for the second-stage interaction is the interaction between the share of footsoldier casualties and the same elite strength variable. ${ }^{23}$ In Panels C and D, we show the reduced form, where we directly interact the share of footsoldier casualties with the elite organization variables. ${ }^{24}$

The results are interesting. The interactions with the landowner associations are important for the early rise of Fascism, which is consistent with the historical record, where the support of large landholders to the Fascist cause, and against agrarian strikes and against worker and sharecropper demands, was critical for the rise of the Fascist movement in the countryside. These interactions do not appear to be important for the vote share in 1924. In contrast, the presence of entrepreneurs and rentiers matters more for the Fascist vote share in 1924, consistent with the business community and both small and large entrepreneurs supporting, voting for and organizing the vote for the Fascist Party in 1924.

In addition, Table A11 in the Appendix looks at a dummy for sizable donations to the Fascist Party from the area as an outcome variable. The Socialist Party's vote share in the 1919 elections does not have a statistically significant main effect on this variable, but it has a significant interaction with local elite presence, which suggests that in areas where there were landowner associations or more entrepreneurs and rentiers in the population, a higher vote share for Socialists made potential donors more likely to make significant donations to the Fascist movement. This result, too, is consistent with large landowners and business interests turning to the Fascist Party when they started fearing further demands and gains by Socialists.

Overall, the various pieces of evidence in this section corroborate (though, of course, not prove) our causal mechanism - that the rise of Italian fascism was due to the center-right, landholders and business community starting to tolerate and support them because of their fear of Socialists and their demands.

\footnotetext{
${ }^{23}$ Since these elite organization variables are not exogenous to other characteristics of the municipality, their interactions may still suffer from endogeneity and these results should be interpreted with more caution than our other estimates.

${ }^{24}$ Table A12 in the Appendix shows the reduced forms for our main results (corresponding to Tables 4-6) for comparison.
} 


\section{Results with Other Sources of Variation}

Our main hypothesis concerns the effect of the perceived threat of socialism in post-WWI Italy on the rise of fascism. The reliability of the results reported so far turns on the excludability of our main instrument, footsoldier casualties. Though the falsification exercises in Table 3 bolster our confidence in this exclusion restriction, it would be informative and comforting if other sources of variation generating greater perceived threat of socialism also led to a similar surge in local Fascist support. We investigate this question in the current section using two entirely different sources of variation: the effects of the Spanish flu and droughtinduced economic hardship, both of which, as we document, increased the support for the Socialist Party in the area. We then show that these sources of variation led to a similarly large increase in Fascist activity as well, though these effects are less precisely estimated than our main results.

\subsection{The Spanish Flu and the Support for Socialism}

The Spanish flu pandemic, which affected Europe in 1918 and killed about 50 million people around the world (Johnson and Mueller, 2002), was almost as deadly and disruptive as the Great Warspace in Italy. ${ }^{25}$ The hardship and the economic distress it created also fueled discontent with the existing regime and increased the electoral appeal of Socialists. We therefore look at the severity of the Spanish flu, measured as the number of excess deaths in the municipality in 1918, as an additional source of variation. One appealing aspect of this source of variation is that, while our main sample is dominated by rural municipalities and the drought instrument we use in the next subsection is mainly for the countryside as well, the Spanish flu impacted urban areas more than the rural areas and our sample for this exercise includes 207 urban municipalities. ${ }^{26}$ In Appendix Table A13 we investigate whether our variable for excess deaths from Spanish flu predicts the pre-1919 economic, social and political variables we used in Table 2. We see a negative relationship with industrial strikes in 1913-14, and a positive association with the share of industrial workers in municipality population in 1911 in one of the specifications. These correlations likely reflect the fact that the Spanish flu more severely impacted dense urban areas, which tended to have more industrial workers. The other ten variables show no correlation with excess mortality from Spanish flu. Overall, even if not uncorrelated with all other municipality characteristics as our footsoldier casualty variable, these results support the notion that excess deaths from Spanish flu are unlikely to be systematically related to prior support for Socialists or Fascists, especially since there is no correlation between this variable and prior voting patterns.

Panel A of Table 9 shows results exploiting this source of variation. The first two columns show a

\footnotetext{
${ }^{25}$ Istituto Centrale di Statistica (1958). We computed the excess deaths in 1918 compared to 1911-1914, which leads to about 494,500 excess deaths. This estimate, even if larger than the severely undercounted official estimate of 275,000, is in line with others, e.g. Tognotti (2015), and is also comparable to the estimates of the number of Italian soldiers who died in the war, estimates of which range between 510,000 and 600,000.

${ }^{26}$ Using data from Direzione Generale della Statistica e del Lavoro (1917-1924) we compute a 83\% average excess rate in 1918 for urban municipalities as compared to $69 \%$ excess mortality for rural municipalities with respect to the 1911-1914 average.
} 
precisely-estimated positive impact of the excess deaths variable on the Socialist vote share in 1919, which will be our first stage. Throughout this table, we focus on columns 4 and 6 from our baseline table structure in Table 1. The rest of the columns show the 2SLS estimates using this source of variation. There is a positive impact on the Fascist vote share in 1924 and Fascist branches in 1921, but these estimates are only marginally significant or just below significance. We do not find a systematic relationship between the Socialist vote share in 1919 and Fascist violence when using the source of variation. The implied quantitative magnitudes are similar to those we saw with our main results. A one standard deviation increase in the Socialist vote share in 1919 is predicted to raise the Fascist vote share in 1924 by 20 percentage points. $^{27}$

Overall, even though the estimates using the Spanish flu are not as precise, the fact that they go in the same direction as our main results bolsters our confidence in the interpretation that the causal chain is running from economic hardship and discontent to the electoral and political success of Socialists and then as a reaction to this, to greater support for Fascists in the early 1920s.

\subsection{Drought in 1918-1919}

Another source of major hardship in early 20th century was drought in agricultural areas. There are several papers using fluctuations in rainfall as a source of variation for civil wars, democratic transitions, revolutions, protests and other political economy outcomes. ${ }^{28}$ In previous work, Acemoglu et al. (2019) showed that the severe drought in 1893 in Sicily boosted the support for peasant organizations, which were strongly allied with the Socialist Party. A medium-size drought in the winter-spring of 1918-9 (the second-most severe of the years between 1915-1928 after the 1921 European drought) impacted parts of Italy, including the Po Valley, Tuscany and Sardinia. Here we investigate whether the drought-induced hardships and discontent also increased the support for the Socialist Party in the 1919 elections and whether this again boosted the subsequent Fascist fortunes.

We adopt the same parameterization as in Acemoglu et al. (2019). Namely, we measure the extent of drought conditions by relative rainfall (benchmarked to rainfall in the years 1915-1979) and cap this variable at one (so that we do not exploit the variation coming from more rain than usual). As explained in Section 3, our rainfall data come from 427 weather stations throughout Italy. In Table A14 in the Appendix, we show that our relative rainfall variable is uncorrelated with most of the pre-1919 economic, social and political characteristics. The exceptions are the dummy for the presence of many landowners, industrial workers divided by male population in 1911 and the crime rate in 1874, which are negatively associated with this variable. More importantly, Socialist vote share in 1913 is also negatively correlated with our rainfall variable. These correlations suggest that our drought-instrumented estimates should be interpreted

\footnotetext{
${ }^{27}$ This should be compared with the 13 percentage points higher vote share for the Fascist Party implied by the most loaded specification in column 6 of Table 3.

${ }^{28}$ See, among others, Brückner and Ciccone (2011); Dell (2012); Dell et al. (2014); Madestam et al. (2013); Miguel et al. (2004); Bonnier et al. (2015); Hsiang et al. (2011, 2013); Waldinger (2013).
} 
with greater caution than our earlier results, even though we control for these variables in our regression models.

Our main results are presented in Panel B of Table 9. The first two columns show the first-stage relationship between our relative rainfall variable and the Socialist vote share in 1919. The remaining columns show that there is a positive association between the instrumented Socialist vote share in 1919 and the Fascist vote share in 1924 (but we do not detect a significant relationship with our other measures of local Fascist activity). Comfortingly, Table A15 in the Appendix, which focuses on the reduced-form relationship (analogous to the IV models for the Fascist vote share in 1924 reported in columns 3 and 4 here), documents that this statistical association between relative rainfall and the subsequent Fascist electoral performance is not present when we look at rainfall in other years with one exception, significant at the $10 \%$ level.

Overall, even though these results are weaker and have to be interpreted with greater caution (especially given the correlation of our rainfall variable with some prior municipality characteristics), they are consistent with our key argument — that shocks that increased the Socialist vote share in 1919 subsequently led to a reaction from other segments of society, including from urban and rural elites, and contributed to the rise of Fascism in Italy.

\section{Medium-Term and Long-Term Outcomes}

Did the support for and the rule of the Fascist Party in Italy have a longer-term impact? There is no consensus answer to this question. The Fascist takeover of power was an epochal event, which could have altered Italy's subsequent economic or political trajectory. On the other hand, the Fascist government lost most of its legitimacy and disintegrated in the middle of WWII in September 1943, as the allied forces invaded southern Italy and set up "Kingdom of the South", and the puppet "Republic of Salò " headed by Mussolini but de facto ruled by German Nazis, came to control the north. The Salò regime, too, conclusively collapsed at the end of WWII, and Mussolini was duly executed. Given the abrupt and complete end to Fascist rule in Italy, it is possible that it had minimal impact on later events, including post-war political developments. We briefly investigate these issues in this section. We start with the potential impact of local Fascist support on the deportation of Jews from Italy, and then turn to its potential effects on post-war political alignments.

\subsection{Deportation of Jews}

About 8000 Jewish citizens and refugees were deported from Italy to various concentration camps towards the end of the war, mostly under the Republic of Salò. The early literature downplayed the role of Italians in the deportation and murder of Jews (De Felice, 1961; Zuccotti, 1987). Recent studies have revised this historiography, emphasizing the involvement of Italian forces, Fascist sympathizers and the general population in the arrest and deportation of Jews (Sarfatti, 2006; Levis Sullam, 2018). In Table 10, we look 
at the relationship between local support for Fascists in the 1920s and the deportation of Jews from the same area two decades later. Namely, we estimate regressions similar to equation (2), except that the key right-hand side variable is the vote share of the Fascist Party in 1924, and is instrumented, similar to (1), with the share of footsoldier casualties in WWI. The interpretation is that the key intervening variable is local support for and organization of Fascists, proxied by the Fascist vote share in 1924 (and thus, we are not thinking of the Fascist vote share as the intervening variable itself, but rather as a proxy for local support for the movement). Given our results so far, footsoldier casualties are an attractive source of variation for this local fascist activity.

In Table 10, we look at three measures. In Panel A we consider a dummy variable for whether any Jews were deported from the municipality. In Panel B, we focus on estimates of deported Jews over a rough estimate of Jewish population in the municipality (as explained in Section 3). Finally, in Panel C, we consider a similar measure, but exclude all municipalities with concentration camps in which Jews from other areas were temporarily gathered and later deported to Nazi camps. Since these camps may have been set up in the area outside of its residents control or wishes, variation coming from deportation from camps may not be informative about local support for Jewish deportations. In all panels, we have the same six specifications we have used in our main tables.

In all panels and throughout the six specifications, we find statistically significant and sizable associations between local fascist activity (proxied by the Fascist vote share in 1924) and Jewish deportations. For example, the coefficient of 0.862 (standard error $=0.437$ ) in column 6 in Panel A implies that a one standard deviation increase in the Fascist vote share in 1924 is associated with 22\% greater likelihood of Jews being deported from that municipality.

In Tables A16 in the Appendix, we show that these relationships are robust when we restrict the sample to municipalities in the Republic of Salò or when we use alternative measures of Jewish deportations. ${ }^{29}$ This table demonstrates that our results are fairly robust across specifications and are not sensitive to the exact measurement strategy.

Overall, these findings show that local fascist support may have had some medium-run effects and also support the more recent historiography on the role of Italian Fascists in the deportation of local Jews.

\subsection{Post-War Political Alignments}

In this subsection, we investigate whether there were any durable political consequences of Italian Fascism. In Table 11, we look at longer-term political effects of the vote share of the Fascists in the 1924 election, and instrument this variable once again with equation (1). In particular, we focus on the vote shares of various parties in post-WWII elections. Since the number and names of parties have changed in Italy over the last 70 years, we group different parties into four categories: left, center-right, extreme left and extreme right.

\footnotetext{
${ }^{29}$ Appendix Table A17 reports the reduced-form relationship between footsoldier casualties and Jewish deportations.
} 
For example, center-right includes the Christian Democrats for most of the post-war elections, while the left includes socialists and communists (which, by the early 1970s, had largely assumed a social democratic platform). The extreme right includes various nationalist or neofascist movements, such as MSI until 1992 and its successors, while extreme left includes the Communist Internationalist Party (in the 1946 and 1948 elections) and then DP (Proletarian Democracy) and other minor lists, which in the 1960s and 1970s filled the space on the left vacated by the communists. Column 1 pools data from all elections between 1946 and 2018, while the remaining 19 columns (nine in Panel A and another 10 in Panel B) look at one election at a time. In all specifications, we focus on the set of covariates used in our most demanding specification, column 6 in our usual table structure. We find a consistent and sizable negative effect of the local support for the Fascist Party in the 1924 election on center-right vote share in almost all elections. In the pooled specification, we see a coefficient of -0.418 (standard error $=0.167)$, which implies that a 10 percentage point greater support for the fascist party is associated with more than a $4 \%$ decline in the vote share of the center-right parties. Most of this vote loss goes to the left, but some of it is captured by the extreme left as well. Only in two elections we see a small and marginally significant positive effect on the extreme right.

Our interpretation for these results is as follows: the fact that, in response to the perceived threat of socialism, the center-right fell behind Fascists in the 1920s, may have damaged the long-term reputation of center-right parties in the area. We should, however, note that we are not able to rule out an alternative interpretation: the instrumented Fascist vote share in 1924 may also be capturing some of the longer-term effects of the Socialist support in 1919 election. The reason why we are not favoring this interpretation is that, as our results in Table 7 demonstrated, much of the boost that the Socialists had received from war disruption had already dissipated by 1924, and thus we suspect that it is not the cause of the long-term effects on the political fortunes of center-right parties in the municipality.

\section{Conclusion}

This paper revisited the rise of Fascism in Italy. We argued that Italian Fascism benefited from the perceived threat of Socialism in the aftermath of WWI, which made many landowners and businesses turn to them, and many center-right voters join them, in order to combat Socialist workers' demands or the general red scare in Italy. The Socialist Party was in the ascendancy after the war and had shifted to the left, both because of its internal dynamics and under the influence of the Bolshevik Revolution.

We documented a strong association between WWI casualties in an area and the vote share of the Socialist Party in the 1919 elections. We further argued that this relationship is not explained by any pre1919 economic, social or political characteristics of the municipality; rather, it captures the effects of the hardship and disillusionment felt by combatants and their families. We bolstered this interpretation by showing that such casualties are not associated with greater votes for nationalist or pro-war parties in the 1919 elections. Nor are they correlated with the subsequent erection of nationalist symbols, such as war 
memorials, in the area. We then used this source of variation to isolate the rise in local support for Fascists in response to this perceived threat of socialism.

We further bolstered this interpretation by providing various pieces of evidence in support of our proposed mechanism. These include the fact that the votes for the Fascist Party did not come at the expense of the Socialists, but from center-right parties such as Nationalists, the Agrarian Party or the Popular Party. We also showed that the effects are larger in municipalities where business or landowning interests were organized and supported the fascist cause.

A key question is what generalizable lessons we can learn from this episode in Italy. The most direct parallel is to the Nazi takeover of power in Germany, which may have also received additional support from those who feared socialist or communist politics (e.g. Evans, 2006). The rise of the Franco regime in Spain, which included major fascist elements, has also been linked to the threat of socialism and political instability that characterized the brief experience of the Spanish Second Republic (see, for example, Jackson, 1965; Preston, 2007; Casanova, 2010; Domenech, 2013) A number of right-wing authoritarian military coups in Latin America, most notably Pinochet's overthrow of Salvatore Allende's government in 1971, presented themselves as bulwarks against socialism and communism (Valenzuela and Constable, 1991; Nef, 1983; Sigmund, 1977).

All the same, Italian Fascism and Nazism, as historical phenomena, were in many ways unique to the post-WWI era, in which society and politics had become militarized and the threat of a socialist/communist revolution was real and feared in many parts of Europe. Our results are consistent with this view, and as such suggest that the recent surge in the popularity of right-wing authoritarian or populist parties is unlikely to turn into classic fascism (even if they are sometimes argued to have many fascist elements (e.g., Stanley, 2018)). One open question is whether some other perceived threat, such as from disruptive cultural change or immigration, could play the same role as the red scare in Germany and Italy, and embolden far right political movements while also broadening their appeal (Skocpol and Williamson, 2016). It is therefore important to investigate this issue in future work, for example, by exploring whether local support for extreme right-wing movement increases when there are more fundamental threats to existing social arrangements or greater economic hardship as in the post-WWI era.

\section{References}

Acemoglu, D., De Feo, G., and De Luca, G. D. (2019). Weak States: Causes and Consequences of the Sicilian Mafia. The Review of Economic Studies, 87(2):537-581.

Adena, M., Enikolopov, R., Petrova, M., Santarosa, V., and Zhuravskaya, E. (2015). Radio and the Rise of the Nazis in Prewar Germany. The Quarterly Journal of Economics, 130(4):1885-1939. 
Adorno, T., Frenkel-Brunswik, E., and Levinson, D. (1950). The Authoritarian Personality. Social studies series. Harper.

Berg, H., Dahlberg, M., and Vernby, K. (2019). Post-WWI military disarmament and interwar fascism in Sweden. Historical Methods: A Journal of Quantitative and Interdisciplinary History, 52(1):37-56.

Bianchi, R. (2014). Social Conflict and Control, Protest and Repression (Italy). In Daniel, U., Gatrell, P., Janz, O., Jones, H., Keene, J., Kramer, A., and Nasson, B., editors, 1914-1918-online. International Encyclopedia of the First World War. Freie Universität Berlin, Berlin.

Bonnier, E., Poulsen, J., Rogall, T., and Stryjan, M. (2015). Preparing for Genocide: Quasi-Experimental Evidence from Rwanda. Uppsala Universitet, Department of Economics Working Paper 2015-1.

Brückner, M. and Ciccone, A. (2011). Rain and the Democratic Window of Opportunity. Econometrica, 79(3):923-947.

Brustein, W. (1991). The "Red Menace" and the Rise of Italian Fascism. American Sociological Review, 56(5):652-664.

Cardoza, A. L. (1982). Agrarian Elites and Italian Fascism: The Province of Bologna, 1901-1926. Princeton University Press, Princeton, NJ.

Casanova, J. (2010). The Spanish Republic and Civil War. Cambridge University Press, Cambridge, UK.

Ceva, L. (1999). Storia delle forze armate in Italia. UTET libreria, Torino.

Corbetta, P. and Piretti, M. S. (2009). Atlante storico-elettorale d'Italia: 1861-2008. Zanichelli.

Corner, P. (1975). Fascism in Ferrara 1915-1925. Oxford University Press, London.

De Felice, R. (1961). Storia degli ebrei sotto il fascismo. Einaudi.

De Felice, R. (1965). Mussolini il rivoluzionario. Einaudi.

De Felice, R. (1966). Mussolini il fascista: 1. La conquista del potere, 1921-1925., volume 1. Einaudi, Torino: IT.

Dell, M. (2012). Path Dependence in Development: Evidence from the Mexican Revolution. mimeo.

Dell, M., Jones, B. F., and Olken, B. A. (2014). What Do We Learn from the Weather? The New ClimateEconomy Literature. Journal of Economic Literature, 52(3):740-798.

Demers, F. J. (1979). Le origini del fascismo a Cremona. Laterza, Bari.

Direzione Generale della Statistica (1924). Statistica delle Elezioni Generali Politiche per la XXVII Legislatura (6 Aprile 1924). Ministero dell’Economia Nazionale.

Direzione Generale della Statistica e del Lavoro (1912). Le Organizzazioni Padronali. 1: Le agrarie. Ministero di agricoltura, industria e commercio, Roma.

Direzione Generale della Statistica e del Lavoro (1917-1924). Movimento della Popolazione Secondo gli Atti dello Stato Civle. Ministero per l'Industria, il Commercio e il Lavoro.

Doerr, S., Gissler, S., Peydro, J.-L., and Voth, H.-J. (2020). From finance to fascism. Technical Report 
3146746, SSRN.

Domenech, J. (2013). Rural labour markets and rural conflict in Spain before the Civil War (1931-6)1. The Economic History Review, 66(1):86-108.

Elazar, D. S. (2000). Electoral democracy, revolutionary politics and political violence: the emergence of Fascism in Italy, 1920-21. Br J Sociol, 51(3):461-488.

Elazar, D. S. and Lewin, A. C. (1999). The Effects of Political Violence: A Structural Equation Model of the Rise of Italian Fascism (1919-1922). Social Science Research, 28(2):184-202.

Evans, R. (2006). The Third Reich in Power, 1933-1939. Penguin Books. Penguin Books.

Fontana, N., Nannicini, T., and Tabellini, G. (2018). Historical Roots of Political Extremism: The Effects of Nazi Occupation of Italy. Technical Report 3091588, SSRN.

Franzinelli, M. (2003). Squadristi: protagonisti e tecniche della violenza fascista, 1919-1922. Mondadori, Milano, IT.

Fromm, E. (1941). Escape from Freedom. Holt, Rinehart \& Winston, New York, NY.

Galofré-Vilà, G., Meissner, C. M., McKee, M., and Stuckler, D. (2017). Austerity and the rise of the Nazi party. Technical report, National Bureau of Economic Research.

Gerwarth, R. (2016). The Vanquished: Why the First World War Failed to End. Macmillan.

Griffin, R. (1991). The Nature of Fascism. Routledge.

Hsiang, S. M., Burke, M., and Miguel, E. (2013). Quantifying the Influence of Climate on Human Conflict. Science, 341(6151).

Hsiang, S. M., Meng, K. C., and Cane, M. A. (2011). Civil conflicts are associated with the global climate. Nature, 476(7361):438-441.

Istituto Centrale di Statistica (1958). Cause di morte 1887-1955. Istituto Centrale di Statistica, Roma.

Jacini, S. (1882-1885). Atti della Giunta per la Inchiesta Agraria e sulle Condizione della Classe Agricola. Forzani e C., Tipografi del Senato, Roma.

Jackson, G. (1965). Spanish Republic and the Civil War, 1931-1939. Princeton University Press, Princeton, NJ.

Johnson, N. P. A. S. and Mueller, J. (2002). Updating the Accounts: Global Mortality of the 1918-1920 "Spanish" Influenza Pandemic. Bulletin of the History of Medicine, 76(1):105-115.

Kershaw, I. (2015). The Nazi Dictatorship: Problems and Perspectives of Interpretation. Bloomsbury Revelations. Bloomsbury Publishing.

King, G., Rosen, O., Tanner, M., and Wagner, A. F. (2008). Ordinary Economic Voting Behavior in the Extraordinary Election of Adolf Hitler. The Journal of Economic History, 68(4):951-996.

Koening, C. (2015). Loose Cannons - War Veterans and the Erosion of Democracy in Weimar Germany. Economics Research Paper 1079, Warwick 1079. 
Laclau, E. (1977). Politics and ideology in Marxist theory. New Left Books, London, UK.

Lasswell, H. D. (1933). The Psychology of Hitlerism. The Political Quarterly, 4(3):373-384.

Levis Sullam, S. (2018). The Italian Executioners: The Genocide of the Jews of Italy. Princeton University Press, Princeton, NJ.

Lipset, S. M. (1955). The Radical Right: A Problem for American Democracy. The British Journal of Sociology, 6(2):176-209.

Lupo, S. (2005). Il fascismo: la politica in un regime totalitario. Donzelli Editore.

Lyttelton, A. (2003). The Seizure of Power: Fascism in Italy, 1919-1929. Routledge, 3rd edition.

Madestam, A., Shoag, D., Veuger, S., and Yanagizawa-Drott, D. (2013). Do Political Protests Matter?

Evidence from the Tea Party Movement. The Quarterly Journal of Economics, 128(4):1633-1685.

Maier, C. S. (1988). Recasting Bourgeois Europe. The University of Chicago Press, Princeton, NJ, 2nd edition.

Miguel, E., Satyanath, S., and Sergenti, E. (2004). Economic Shocks and Civil Conflict: An Instrumental Variables Approach. Journal of Political Economy, 112(4):725-753.

Ministero della Guerra, U. S. (1927). La forza dell'esercito: Statistica dello Sforzo Militare Italiano nella Guerra Mondiale. Provveditorato Generale dello Stato (libr.).

Ministero di Grazia e Giustizia e dei Culti (1875). Statistica degli Affari Civili e Commerciali e degli Affari Penali per l'anno 1874.

Ministero per il Lavoro e la Previdenza Sociale (1914). Bollettino del Lavoro e della Previdenza Sociale, volume XXI. Tipografia dell'Unione Editrice - Grafia, Roma, IT.

Ministero per il Lavoro e la Previdenza Sociale (1921). Bollettino del Lavoro e della Previdenza Sociale, volume XXXV. Tipografia dell'Unione Editrice - Grafia, Roma, IT.

Moore, B. (1966). Social Origins of Dictatorship and Democracy: Lord and Peasant in the Making of the Modern World. Beacon Press, Boston, MA.

Nef, J. (1983). The Revolution that Never was: Perspectives on Democracy, Socialism, and Reaction in Chile. Latin American Research Review, 18(1):228-245.

Nolte, E. (1965). Three Faces of Fascism. Holt, Rinehart and Winston.

Ortega Y Gasset, J. (1932). The Revolt of the Masses. New American Library.

Padulo, G. (2010). I finanziatori del fascismo. Le Carte e La Storia, Quaderni.

Pareto, V. (1974). Scritti politici. Utet.

Parsons, T. (1942). Some Sociological Aspects of the Fascist Movements. Social Forces, 21(2):138-147.

Payne, S. (1996). A History of Fascism, 1914-1945. University of Wisconsin Press.

Preston, P. (2007). The Spanish Civil War. Reaction, Revolution and Revenge. W.W Norton \& Co., New York, NY. 
Ragionieri, E. (1976a). Storia d'Italia dall'Unità ad Oggi. Dall'Italia Fascista all'Italia Repubblicana, volume 12. Giulio Einaudi Editore.

Ragionieri, E. (1976b). Storia d'Italia dall'Unità ad Oggi. Lo Stato Liberale, volume 11. Giulio Einaudi Editore.

Sarfatti, M. (2006). The Jews in Mussolini's Italy: from equality to persecution. Univ of Wisconsin Press.

Satyanath, S., Voigtländer, N., and Voth, H.-J. (2017). Bowling for Fascism: Social Capital and the Rise of the Nazi Party. Journal of Political Economy, 125(2):478-526.

Schiavi, A. (1914). Le forze e i programmi dell'opposizione nell'ultima campagna elettorale politica. $L a$ Riforma Sociale, XXV (3rd series):413-430.

Sigmund, P. E. (1977). The Overthrow of Allende and the Politics in Chile, 1964-1976. University of Pittsburgh Press.

Skocpol, T. and Williamson, V. (2016). The Tea Party and the remaking of Republican conservatism. Oxford University Press.

Snowden, F. M. (1972). On the Social Origins of Agrarian Fascism in Italy. European Journal of Sociology, 13(2):268-295.

Stanley, J. (2018). How Fascism Works: The Politics of Us and Them. Random House.

Sternhell, Z., Sznajder, M., Maisel, D., and Ashéri, M. (1994). The Birth of Fascist Ideology: From Cultural Rebellion to Political Revolution. Princeton paperbacks. Princeton University Press.

Tasca, A. (1938). The Rise of Italian Fascism: 1918-1922. Methuen \& Company, Grantham, UK.

Tognotti, E. (2015). La Spagnola in Italia. Franco Angeli, 2nd edition.

Ufficio Centrale di Statistica (1920). Statistica delle Elezioni Generali Politiche per la XXV Legislatura (16 Novembre 1919). Ministero per l'Industria, il Commercio ed il Lavoro.

Valenzuela, A. and Constable, P. (1991). A nation of enemies: Chile under Pinochet. WW Norton \& Company, New York, NY.

Voigtländer, N. and Voth, H.-J. (2012). Persecution Perpetuated: The Medieval Origins of Anti-Semitic Violence in Nazi Germany. The Quarterly Journal of Economics, 127(3):1339-1392.

Voigtländer, N. and Voth, H.-J. (2019). Highway to Hitler. Working Paper 20150, NBER.

Volpi, C. (1919). Cronaca sociale. Rivista Internazionale di Scienze Sociali e Discipline Ausiliarie, 81(324):235-243.

Waldinger, M. (2013). Drought and the French Revolution: The effects of adverse weather conditions on peasant revolts in 1789. Technical report, London School of Economics.

Wellhofer, E. S. (2003). Democracy and Fascism: Class, Civil Society, and Rational Choice in Italy. American Political Science Review, 97(1):91-106.

Zuccotti, S. (1987). The Italians and the Holocaust: Persecution, Rescue. Survival. 
Figure 1: Distribution of Fascist and Socialist support, and footsoldiers casualties

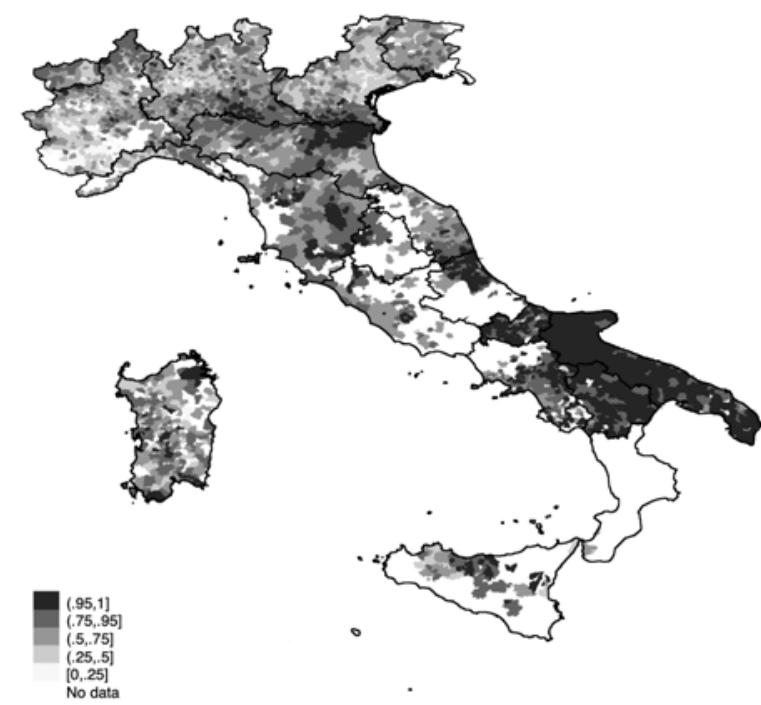

(a) Fascist vote share in 1924

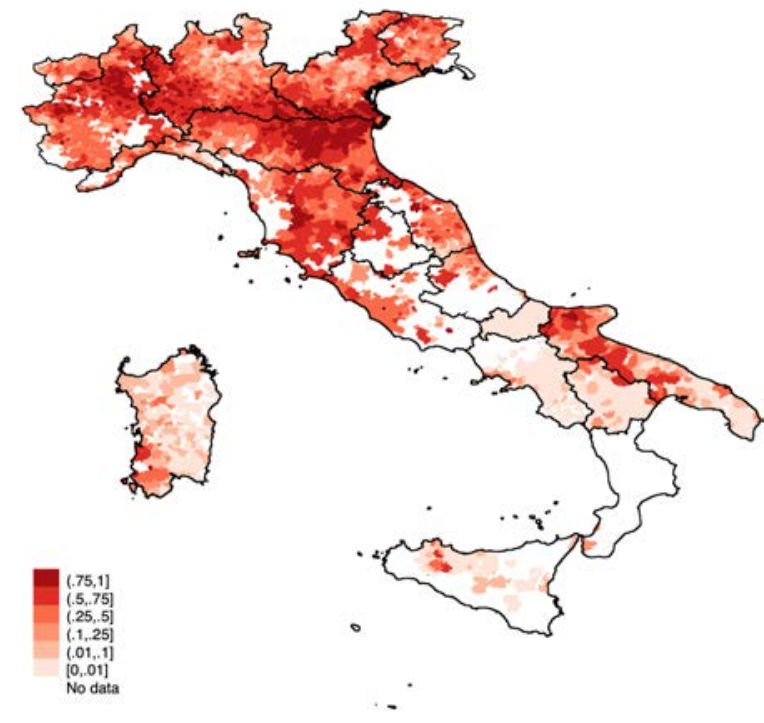

(b) Socialist vote share in 1919

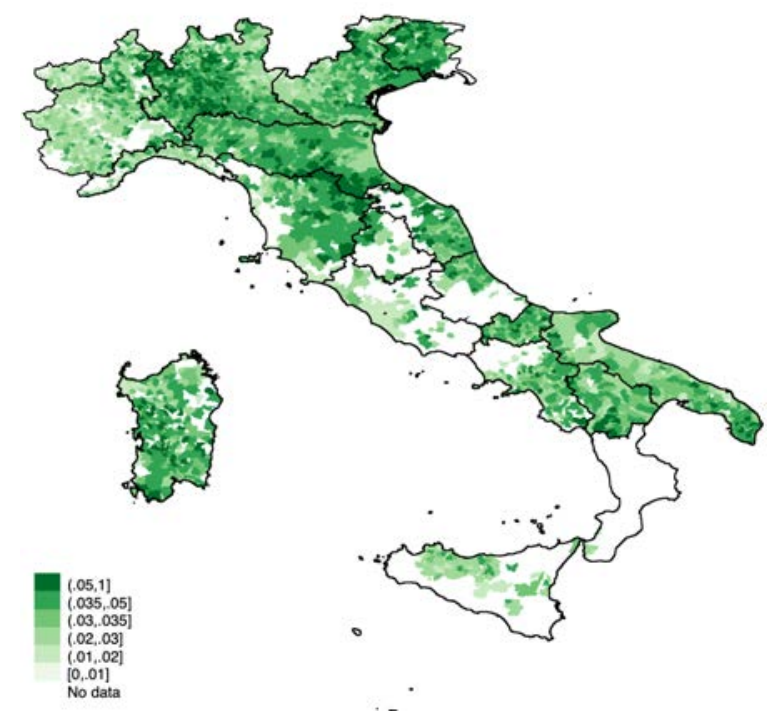

(c) WWI footsoldier casualties 
Figure 2: Bin scatterplot of the first-stage relationship between Socialist vote share in 1919 and footsoldier casualties and the 2SLS relationship between Fascist vote share in 1924 and Socialist vote share in 1919

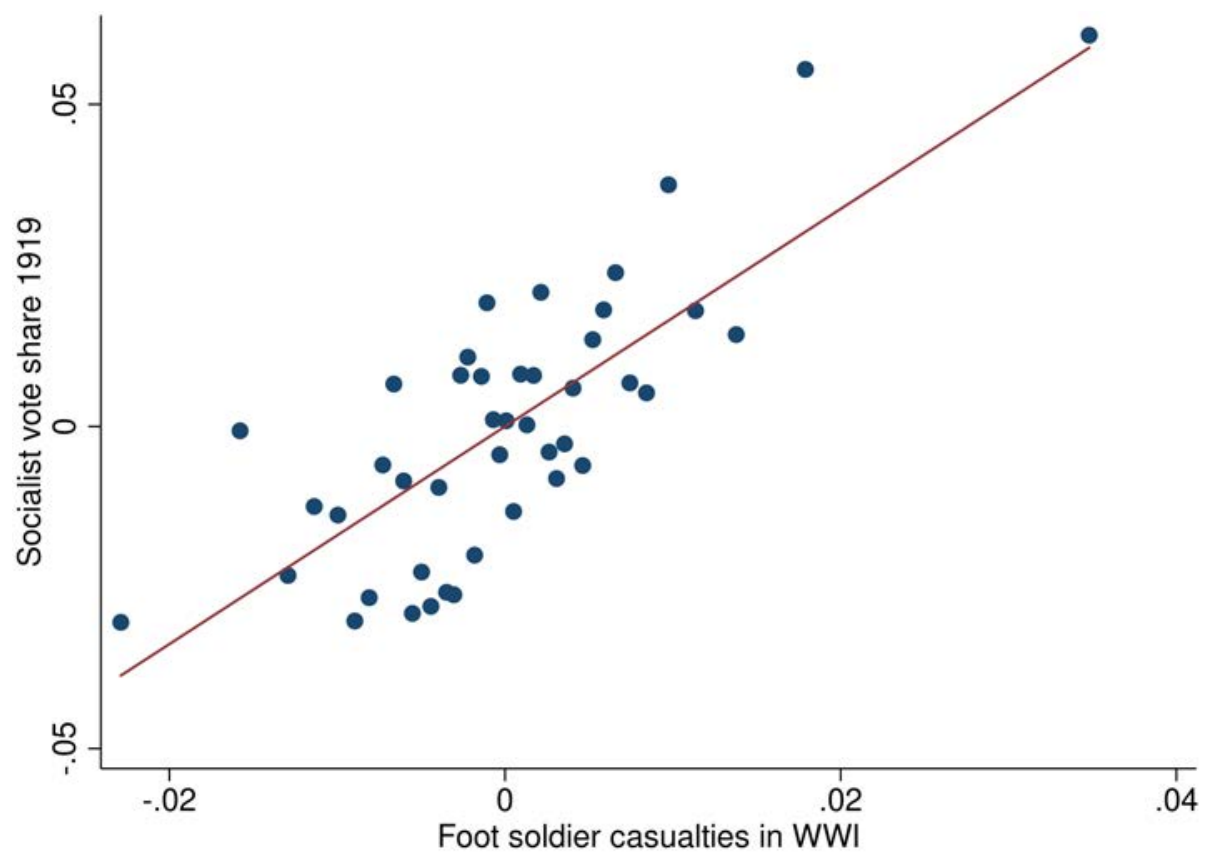

(a) Footsoldier casualties on Socialist vote share in 1919

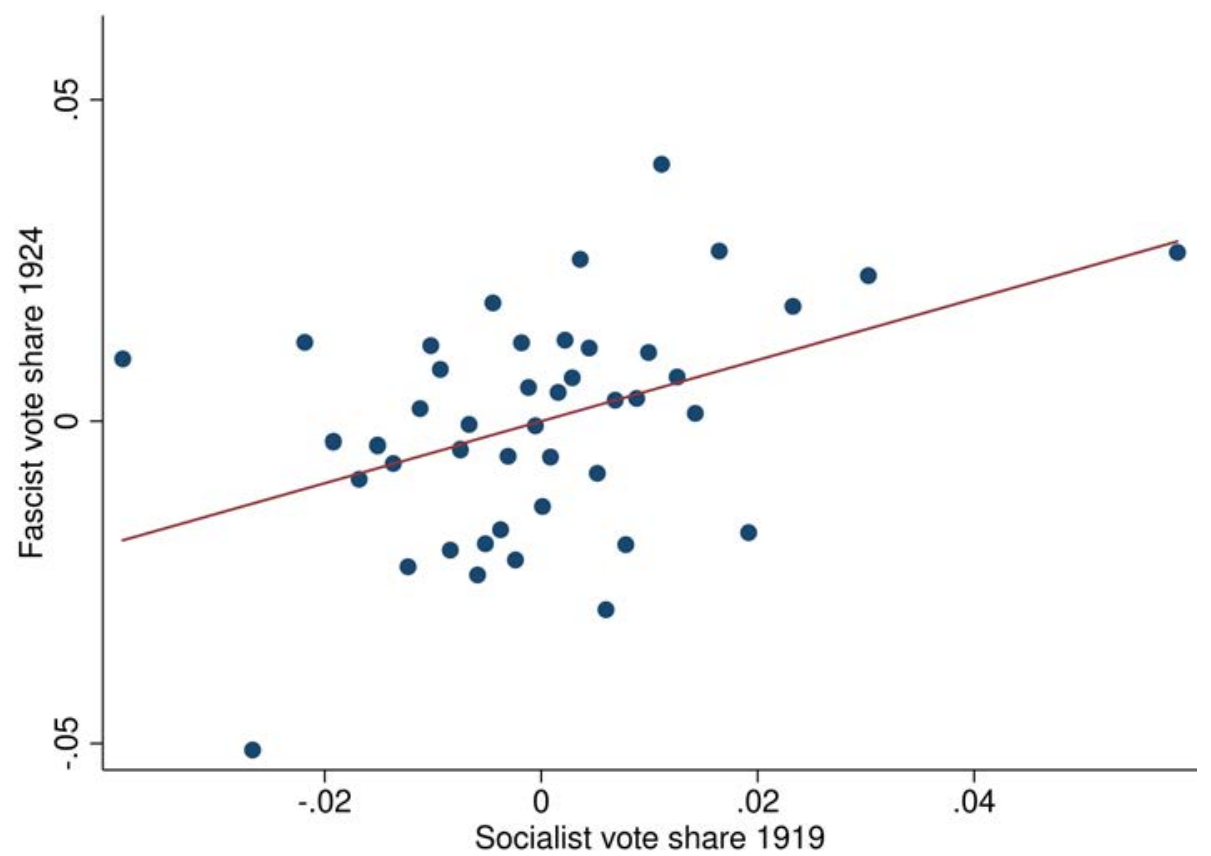

(b) Socialist vote share in 1919 on Fascist vote share in 1924

Notes: The estimate corresponds to the specification from column 6 of Table 1 and Table 3. In panel (b) Socialist vote share in 1919 is instrumented with the count of WWI footsoldier casualties from a municipality divided by the total male population over the age of six in 1911. Please see notes to Table 1 and Table 3. The average bin size is 130 municipalities. 
Figure 3: Bin scatterplot of the 2SLS relationship between Fascist violence and local branches and Socialist vote share in 1919

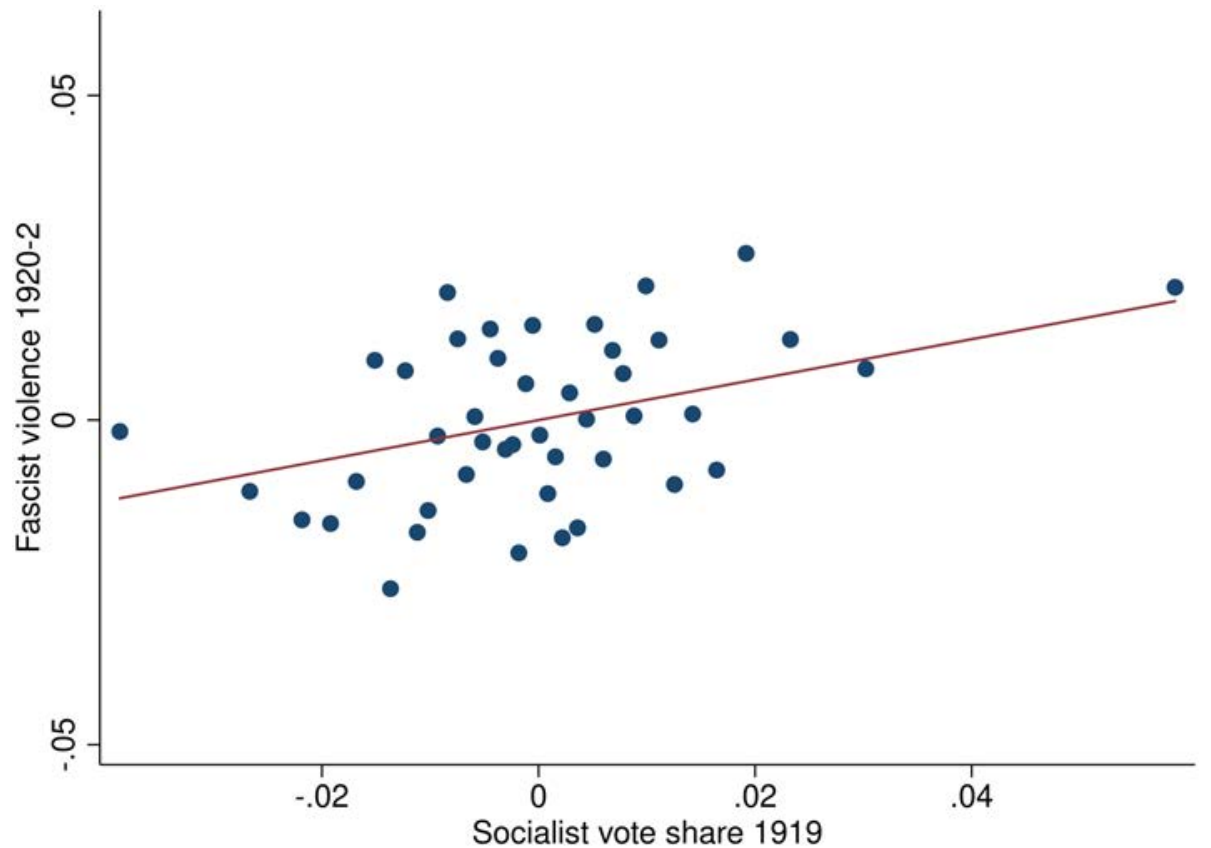

(a) Socialist vote share in 1919 on Fascist violence in 1920-22

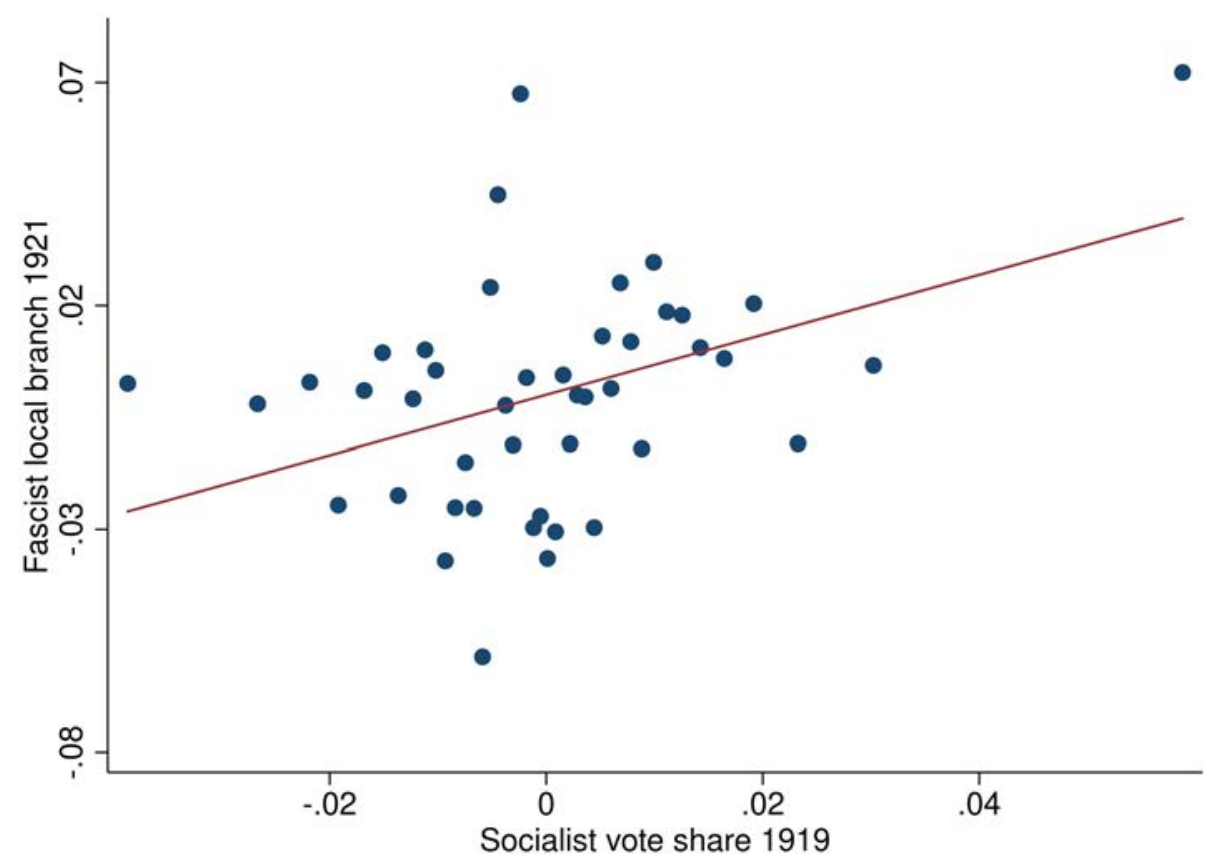

(b) Socialist vote share in 1919 on Fascist local branches in 1921

Notes: The estimates correspond to the 2SLS specification from column 6 of Panel A and Panel B of Table 4. Socialist vote share in 1919 is instrumented with footsoldier casualties. Please see notes to Table 4 . The average bin size is 130 municipalities. 
Table 1: The impact of footsoldier casualties in WWI on the Socialist vote share in 1919

\begin{tabular}{lcccccc}
\hline Dep variable: Socialist vote share in 1919 & $(1)$ & $(2)$ & $(3)$ & $(4)$ & $(5)$ & $(6)$ \\
\hline Share of footsoldier casualties & 2.034 & 1.953 & 1.772 & 1.752 & 1.686 & 1.689 \\
& $(0.315)$ & $(0.300)$ & $(0.236)$ & $(0.231)$ & $(0.230)$ & $(0.234)$ \\
Veterans (classes 1874-1895) & & & & 0.868 & 0.791 & 0.814 \\
& & & & $(0.348)$ & $(0.353)$ & $(0.349)$ \\
Veterans (classes 1896-1900) & & & & -1.487 & -1.411 & -1.362 \\
& & & & $(0.527)$ & $(0.547)$ & $(0.538)$ \\
& & & & & & \\
Regiment/Province FE & $\checkmark$ & $\checkmark$ & $\checkmark$ & $\checkmark$ & $\checkmark$ & $\checkmark$ \\
Demographic controls & $\checkmark$ & $\checkmark$ & $\checkmark$ & $\checkmark$ & $\checkmark$ & $\checkmark$ \\
Geographic controls & & $\checkmark$ & $\checkmark$ & $\checkmark$ & $\checkmark$ & $\checkmark$ \\
Socialist share in 1913 & & & $\checkmark$ & $\checkmark$ & $\checkmark$ & $\checkmark$ \\
Military controls & & & & $\checkmark$ & $\checkmark$ & $\checkmark$ \\
Agriculture controls & & & & & $\checkmark$ & $\checkmark$ \\
Urban controls & & & & & & $\checkmark$ \\
Observations & 5,775 & 5,775 & 5,775 & 5,775 & 5,775 & 5,775 \\
R-squared & 0.599 & 0.617 & 0.691 & 0.693 & 0.695 & 0.697 \\
Number of clusters & 181 & 181 & 181 & 181 & 181 & 181 \\
F-stat & 41.68 & 42.27 & 56.37 & 57.55 & 53.96 & 52.18 \\
\hline
\end{tabular}

Notes: The footsoldier casualty variable is the count of WWI footsoldier casualties from a municipality divided by the total male population over the age of six in 1911. Column 1 includes regiment and province fixed effects and demographic controls (quartic in log population and share of population below the age of six in 1911). Column 2 additionally includes geographic controls (log area, elevation of the main center, and maximum elevation). Column 3 adds Socialist vote share in 1913. Column 4 adds military controls (veterans from classes 1874-1895 and from classes 1896-1900 as well as dummies for any casualties of special assault corps from the municipality, any casualties in the highest-mortality battles, and any casualties among volunteers from the municipality). Column 5 additionally includes agricultural controls (share of day laborers, share of sharecroppers and a dummy for the presence of local agrarian associations). Finally, column 6 adds urban controls (industry workers and industrial firms over male population in 1911, literacy rate in 1911, the share of entrepreneurs and rentiers, and the share of the bourgeoisie). See text for further details. Standard errors clustered at the district level are in parentheses. 
Table 2: Falsification exercises

\section{(1)}

(3)

(4)

(5)

Literacy 1911

Violent crimes 1874

Crime rate 1874

Dep variable:

Socialists 1913

$\begin{array}{ll}0.185 & 0.227\end{array}$

$(0.272)$

$(0.250)$

$-0.146 \quad-0.194$

(0.142)

0.504

(1.838)

0.094

(1.850)

5.734

(6.965)

2.213

0.751

0.198

1.483

1.549

6.431

6.486

Panel B:

Dep variable:

Ind. workers 1911

Ind. firms 1911

Share of footsoldier

$-0.267 \quad-0.284$

casualties

(0.357) (0.351)

$\begin{array}{cc}0.021 & 0.024 \\ (0.019) & (0.017)\end{array}$

Ind. strikes 1913-4

Ind. strikers 1913-4

Mean

SD

0.116

0.216

0.012

0.011

\begin{tabular}{cccc}
0.002 & 0.007 & -0.003 & -0.003 \\
$(0.077)$ & $(0.077)$ & $(0.011)$ & $(0.011)$ \\
0.009 & \multicolumn{2}{c}{0.001} \\
0.094 & \multicolumn{2}{c}{0.014}
\end{tabular}

Panel C:

Dep variable:

Large landholding 1885 Landownership 1885

Agr. strikes 1913-4

Agr. strikers 1913-4

Share of footsoldier

$\begin{array}{ll}0.236 & 0.335\end{array}$

0.485

0.525

$-0.067$

$-0.079$

0.005

0.002

casualties

(0.730)

(0.678)

(0.740)

(0.664)

$(0.050)$

(0.054)

$(0.008)$

(0.008)

Mean

0.416

0.577

0.494

0.003

0.0004

SD

0.495

0.056

0.011

Regiment/Province FE

Demographic controls

Geographic controls

Socialist share in 1913

Military controls

Agriculture controls

Urban controls

$\begin{array}{ll}\checkmark & \checkmark \\ \checkmark & \checkmark \\ \checkmark & \checkmark \\ \checkmark & \checkmark \\ \checkmark & \checkmark \\ & \checkmark \\ & \checkmark\end{array}$

$\begin{array}{ll}\checkmark & \checkmark \\ \checkmark & \checkmark \\ \checkmark & \checkmark \\ \checkmark & \checkmark \\ \checkmark & \checkmark \\ & \checkmark \\ & \checkmark\end{array}$

$\begin{array}{ll}\checkmark & \checkmark \\ \checkmark & \checkmark \\ \checkmark & \checkmark \\ \checkmark & \checkmark \\ \checkmark & \checkmark \\ & \checkmark \\ & \checkmark\end{array}$

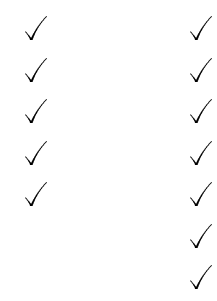

Notes: OLS estimates of the relationship between the count of WWI footsoldier casualties from a municipality divided by the total male population over the age of six in 1911 and the indicated pre-1919 variables. The two specifications correspond to those from columns 4 and 6 in Table 1. Column 4 includes regiment and province fixed effects and demographic controls (quartic in log population and share of population below the age of six in 1911), geographic controls (log area, elevation of the main center, and maximum elevation), the Socialist vote share in 1913, and military controls (veterans from classes 1874-1895 and from classes 1896-1900 as well as dummies for any casualties of special assault corps from the municipality, any casualties in the highest-mortality battles, and any casualties among volunteers from the municipality). Column 6 additionally includes agricultural controls (share of day laborers, share of sharecroppers and a dummy for the presence of local agrarian associations) and urban controls (industry workers and industrial firms over male population in 1911, literacy rate in 1911, the share of entrepreneurs and rentiers, and the share of the bourgeoisie). See text for details on dependent variables. We report mean and standard deviation (SD) of each dependent variable. When the left-hand side variable is among the controls included in one of the specifications, it is not included as an additional right-hand side variable. Standard errors clustered at the district level are in parentheses. 
Table 3: 2SLS estimates of the effects of Socialist vote share in 1919 on Fascist vote share in 1924

Dep variable: Fascist vote share in 1924

(1)

(2)

(3)

(4)

(5)

(6)

Panel A: IV

Socialist vote share in 1919

$\begin{array}{cccccc}0.375 & 0.429 & 0.476 & 0.504 & 0.489 & 0.476 \\ (0.162) & (0.153) & (0.158) & (0.156) & (0.163) & (0.156)\end{array}$

Panel B: OLS

Socialist vote share in 1919

\begin{tabular}{ll}
$-0.016 \quad 0.011$ \\
\hline
\end{tabular}

0.019

0.024

0.019

0.022

(0.044) (0.039)

(0.035)

$(0.032) \quad(0.032)$

(0.032)

\section{Regiment/Province FE \\ Demographic controls \\ Geographic controls \\ Socialist share in 1913 \\ Military controls \\ Agriculture controls \\ Urban controls}

\begin{tabular}{lcccccc} 
Observations & 5,775 & 5,775 & 5,775 & 5,775 & 5,775 & 5,775 \\
Number of clusters & 181 & 181 & 181 & 181 & 181 & 181 \\
\hline
\end{tabular}

Notes: 2SLS (Panel A) and OLS (Panel B) regressions of the Fascist vote share in 1924 on the Socialist vote share in 1919. Excluded instrument is the count of WWI footsoldier casualties from a municipality divided by the total male population over the age of six in 1911. Column 1 includes regiment and province fixed effects and demographic controls (quartic in log population and share of population below the age of six in 1911). Column 2 additionally includes geographic controls (log area, elevation of the main center, and maximum elevation). Column 3 adds Socialist vote share in 1913. Column 4 adds military controls (veterans from classes 1874-1895 and from classes 1896-1900 as well as dummies for any casualties of special assault corps from the municipality, any casualties in the highest-mortality battles, and any casualties among volunteers from the municipality). Column 5 additionally includes agricultural controls (share of day laborers, share of sharecroppers and a dummy for the presence of local agrarian associations). Finally column 6 adds urban controls (industry workers and industrial firms over male population in 1911, literacy rate in 1911, the share of entrepreneurs and rentiers, and the share of the bourgeoisie). Standard errors clustered at the district level are in parentheses. 
Table 4: 2SLS and OLS estimates of the effects of Socialist vote share in 1919 on Fascist violence in 1920-22 and Fascist Party local branches in 1921
(1)
(2)
(3)
(4)
(5)
(6)

Dep variable: Fascist violence in 1920-22 (episodes per 1000 inhabitants)

Panel A: IV

$\begin{array}{lllllll}\text { Socialist vote share in } 1919 & 0.230 & 0.239 & 0.254 & 0.329 & 0.311 & 0.312\end{array}$

$\begin{array}{llllll}(0.112) & (0.116) & (0.125) & (0.126) & (0.126) & (0.122)\end{array}$

Panel B: OLS

$\begin{array}{lllllll}\text { Socialist vote share in } 1919 & 0.064 & 0.058 & 0.049 & 0.050 & 0.045 & 0.047\end{array}$

$\begin{array}{llllll}(0.014) & (0.013) & (0.015) & (0.015) & (0.014) & (0.014)\end{array}$

Dep variable: Presence of local branches of the Fascist party in Fall 1921

Panel C: IV

$\begin{array}{lllllll}\text { Socialist vote share in } 1919 & 0.507 & 0.527 & 0.578 & 0.670 & 0.670 & 0.672\end{array}$

$\begin{array}{llllll}(0.227) & (0.231) & (0.257) & (0.277) & (0.277) & (0.266)\end{array}$

Panel D: OLS

$\begin{array}{lllllll}\text { Socialist vote share in } 1919 & 0.080 & 0.072 & 0.081 & 0.086 & 0.080 & 0.083\end{array}$

$\begin{array}{llllll}(0.026) & (0.026) & (0.030) & (0.030) & (0.029) & (0.028)\end{array}$

\begin{tabular}{lcccccc} 
Regiment/Province FE & $\checkmark$ & $\checkmark$ & $\checkmark$ & $\checkmark$ & $\checkmark$ & $\checkmark$ \\
Demographic controls & $\checkmark$ & $\checkmark$ & $\checkmark$ & $\checkmark$ & $\checkmark$ & $\checkmark$ \\
Geographic controls & & $\checkmark$ & $\checkmark$ & $\checkmark$ & $\checkmark$ & $\checkmark$ \\
Socialist share in 1913 & & & $\checkmark$ & $\checkmark$ & $\checkmark$ & $\checkmark$ \\
Military controls & & & & $\checkmark$ & $\checkmark$ & $\checkmark$ \\
Agriculture controls & & & & & $\checkmark$ & $\checkmark$ \\
Urban controls & & & & & & $\checkmark$ \\
Observations & 5,775 & 5,775 & 5,775 & 5,775 & 5,775 & 5,775 \\
Number of clusters & 181 & 181 & 181 & 181 & 181 & 181 \\
\hline
\end{tabular}

Notes: 2SLS and OLS regressions of the Fascist violence (episodes per 1000 inhabitants) in 1920-22 (Panel A and Panel B) and the presence of local Fascist branches in the Fall of 1921 (Panel C and Panel D) on the Socialist vote share in 1919. Excluded instrument is the count of WWI footsoldier casualties from a municipality divided by the total male population over the age of six in 1911. Column 1 includes regiment and province fixed effects and demographic controls (quartic in log population and share of population below the age of six in 1911). Column 2 additionally includes geographic controls (log area, elevation of the main center, and maximum elevation). Column 3 adds Socialist vote share in 1913. Column 4 adds military controls (veterans from classes 1874-1895 and from classes 1896-1900 as well as dummies for any casualties of special assault corps from the municipality, any casualties in the highest-mortality battles, and any casualties among volunteers from the municipality). Column 5 additionally includes agricultural controls (share of day laborers, share of sharecroppers and a dummy for the presence of local agrarian associations). Finally column 6 adds urban controls (industry workers and industrial firms over male population in 1911, literacy rate in 1911, the share of entrepreneurs and rentiers, and the share of the bourgeoisie). Standard errors clustered at the district level are in parentheses. 
Table 5: OLS estimates of the relationship between Socialist vote share in 1919 and agrarian strikes in 1920

\begin{tabular}{lcccccc}
\hline \multicolumn{2}{l}{ Dep variable: Agrarian strikes in 1920. } & & & & & \\
& $(1)$ & $(2)$ & $(3)$ & $(4)$ & $(5)$ & $(6)$ \\
\hline Socialist vote share in 1919 & 0.204 & 0.186 & 0.190 & 0.197 & 0.200 & 0.200 \\
& $(0.069)$ & $(0.070)$ & $(0.072)$ & $(0.073)$ & $(0.070)$ & $(0.071)$ \\
& & & & & & \\
Regiment/Province FE & $\checkmark$ & $\checkmark$ & $\checkmark$ & $\checkmark$ & $\checkmark$ & $\checkmark$ \\
Demographic controls & $\checkmark$ & $\checkmark$ & $\checkmark$ & $\checkmark$ & $\checkmark$ & $\checkmark$ \\
Geographic controls & & $\checkmark$ & $\checkmark$ & $\checkmark$ & $\checkmark$ & $\checkmark$ \\
Socialist share in 1913 & & & $\checkmark$ & $\checkmark$ & $\checkmark$ & $\checkmark$ \\
Military controls & & & & $\checkmark$ & $\checkmark$ & $\checkmark$ \\
Agriculture controls & & & & & $\checkmark$ & $\checkmark$ \\
Urban controls & & & & & & $\checkmark$ \\
Observations & 5,775 & 5,775 & 5,775 & 5,775 & 5,775 & 5,775 \\
R-squared & 0.777 & 0.778 & 0.778 & 0.779 & 0.784 & 0.785 \\
Number of clusters & 181 & 181 & 181 & 181 & 181 & 181 \\
\hline Nots: OLS
\end{tabular}

Notes: OLS regressions of agrarian strikes in 1920 on Socialist vote share in 1919. Column 1 includes regiment and province fixed effects and demographic controls (quartic in log population and share of population below the age of six in 1911). Column 2 additionally includes geographic controls (log area, elevation of the main center, and maximum elevation). Column 3 adds Socialist vote share in 1913. Column 4 adds military controls (veterans from classes 1874-1895 and from classes 1896-1900 as well as dummies for any casualties of special assault corps from the municipality, any casualties in the highest-mortality battles, and any casualties among volunteers from the municipality). Column 5 additionally includes agricultural controls (share of day laborers, share of sharecroppers and a dummy for the presence of local agrarian associations). Finally column 6 adds urban controls (industry workers and industrial firms over male population in 1911, literacy rate in 1911, the share of entrepreneurs and rentiers, and the share of the bourgeoisie). Standard errors clustered at the district level are in parentheses. 
Table 6: 2SLS estimates of the relationship between Socialist vote share in 1919 and Socialist vote share in 1924

\begin{tabular}{lcccccc}
\hline \multicolumn{2}{l}{ Dep variable: Socialist vote share in 1924} & & & & \\
& $(1)$ & $(2)$ & $(3)$ & $(4)$ & $(5)$ & $(6)$ \\
\hline Socialist vote share in 1919 & 0.132 & 0.118 & 0.102 & 0.096 & 0.117 & 0.128 \\
& $(0.080)$ & $(0.078)$ & $(0.083)$ & $(0.084)$ & $(0.086)$ & $(0.084)$ \\
& & & & & & \\
Regiment/Province FE & $\checkmark$ & $\checkmark$ & $\checkmark$ & $\checkmark$ & $\checkmark$ & $\checkmark$ \\
Demographic controls & $\checkmark$ & $\checkmark$ & $\checkmark$ & $\checkmark$ & $\checkmark$ & $\checkmark$ \\
Geographic controls & & $\checkmark$ & $\checkmark$ & $\checkmark$ & $\checkmark$ & $\checkmark$ \\
Socialist share in 1913 & & & $\checkmark$ & $\checkmark$ & $\checkmark$ & $\checkmark$ \\
Military controls & & & & $\checkmark$ & $\checkmark$ & $\checkmark$ \\
Agriculture controls & & & & & $\checkmark$ & $\checkmark$ \\
Urban controls & & & & & & $\checkmark$ \\
Observations & 5,775 & 5,775 & 5,775 & 5,775 & 5,775 & 5,775 \\
Number of clusters & 181 & 181 & 181 & 181 & 181 & 181 \\
\hline
\end{tabular}

Notes: 2SLS regressions of the Socialist vote share in 1924 on the Socialist vote share in 1919. Excluded instrument is the count of WWI footsoldier casualties from a municipality divided by the total male population over the age of six in 1911. Column 1 includes regiment and province fixed effects and demographic controls (quartic in log population and share of population below the age of six in 1911). Column 2 additionally includes geographic controls (log area, elevation of the main center, and maximum elevation). Column 3 adds Socialist vote share in 1913. Column 4 adds military controls (veterans from classes 1874-1895 and from classes 1896-1900 as well as dummies for any casualties of special assault corps from the municipality, any casualties in the highest-mortality battles, and any casualties among volunteers from the municipality). Column 5 additionally includes agricultural controls (share of day laborers, share of sharecroppers and a dummy for the presence of local agrarian associations). Finally column 6 adds urban controls (industry workers and industrial firms over male population in 1911, literacy rate in 1911, the share of entrepreneurs and rentiers, and the share of the bourgeoisie). Standard errors clustered at the district level are in parentheses. 
Table 7: Correlation between footsoldier casualties and support for Fascism and Nationalism

\begin{tabular}{|c|c|c|c|c|c|c|c|c|}
\hline \multirow[t]{2}{*}{ Dep variable: } & \multicolumn{2}{|c|}{ Fascists 1919} & \multicolumn{2}{|c|}{ Nationalists 1919} & \multicolumn{2}{|c|}{$\begin{array}{c}\text { Per capita } \\
\text { monuments } 1921\end{array}$} & \multicolumn{2}{|c|}{$\begin{array}{l}\text { Monument } \\
1921 \text { dummy }\end{array}$} \\
\hline & $(1)$ & (2) & (3) & (4) & (5) & (6) & (7) & (8) \\
\hline Share of footsoldier casualties & $\begin{array}{c}0.069 \\
(0.050)\end{array}$ & $\begin{array}{c}0.065 \\
(0.048)\end{array}$ & $\begin{array}{c}-0.002 \\
(0.004)\end{array}$ & $\begin{array}{c}-0.002 \\
(0.004)\end{array}$ & $\begin{array}{c}-0.050 \\
(0.334)\end{array}$ & $\begin{array}{c}-0.046 \\
(0.330)\end{array}$ & $\begin{array}{c}-0.188 \\
(0.264)\end{array}$ & $\begin{array}{c}-0.130 \\
(0.266)\end{array}$ \\
\hline Regiment/Province FE & $\checkmark$ & $\checkmark$ & $\checkmark$ & $\checkmark$ & $\checkmark$ & $\checkmark$ & $\checkmark$ & $\checkmark$ \\
\hline Demographic controls & $\checkmark$ & $\checkmark$ & $\checkmark$ & $\checkmark$ & $\checkmark$ & $\checkmark$ & $\checkmark$ & $\checkmark$ \\
\hline Geographic controls & $\checkmark$ & $\checkmark$ & $\checkmark$ & $\checkmark$ & $\checkmark$ & $\checkmark$ & $\checkmark$ & $\checkmark$ \\
\hline Socialist share in 1913 & $\checkmark$ & $\checkmark$ & $\checkmark$ & $\checkmark$ & $\checkmark$ & $\checkmark$ & $\checkmark$ & $\checkmark$ \\
\hline Military controls & $\checkmark$ & $\checkmark$ & $\checkmark$ & $\checkmark$ & $\checkmark$ & $\checkmark$ & $\checkmark$ & $\checkmark$ \\
\hline Agriculture controls & & $\checkmark$ & & $\checkmark$ & & $\checkmark$ & & $\checkmark$ \\
\hline Urban controls & & $\checkmark$ & & $\checkmark$ & & $\checkmark$ & & $\checkmark$ \\
\hline Observations & 5,775 & 5,775 & 5,775 & 5,775 & 5,775 & 5,775 & 5,775 & 5,775 \\
\hline R-squared & 0.251 & 0.257 & 0.496 & 0.496 & 0.091 & 0.093 & 0.211 & 0.214 \\
\hline Number of clusters & 181 & 181 & 181 & 181 & 181 & 181 & 181 & 181 \\
\hline
\end{tabular}

Notes: OLS estimates of the relationship between footsoldier casualties during WWI and the Fascist vote shares in 1919, the Nationalist vote shares in 1919, the number of WWI monuments per 1000 inhabitants in the municipality between 1919 and 1921 and the indicator for the erection of WWI monuments in the municipality between 1919 and 1921 . The two specifications correspond to those from columns 4 and 6 in Table 1. Column 4 includes regiment and province fixed effects and demographic controls (quartic in log population and share of population below the age of six in 1911), geographic controls (log area, elevation of the main center, and maximum elevation), the Socialist vote share in 1913, and military controls (veterans from classes 1874-1895 and from classes 1896-1900 as well as dummies for any casualties of special assault corps from the municipality, any casualties in the highest-mortality battles, and any casualties among volunteers from the municipality). Column 6 additionally includes agricultural controls (share of day laborers, share of sharecroppers and a dummy for the presence of local agrarian associations) and urban controls (industry workers and industrial firms over male population in 1911, literacy rate in 1911, the share of entrepreneurs and rentiers, and the share of the bourgeoisie). Standard errors clustered at the district level are in parentheses. 
Table 8: Heterogeneous effects of Socialist vote share in 1919 on local Fascist support

\begin{tabular}{|c|c|c|c|c|c|c|}
\hline \multirow[t]{2}{*}{ Dep variable: } & \multicolumn{2}{|c|}{$\begin{array}{c}\text { Fascist vote share } \\
\text { in } 1924\end{array}$} & \multicolumn{2}{|c|}{$\begin{array}{l}\text { Fascist violence } \\
\text { in } 1920-2\end{array}$} & \multicolumn{2}{|c|}{$\begin{array}{c}\text { Fascist local branch } \\
\text { in } 1921\end{array}$} \\
\hline & $(1)$ & $(2)$ & $(3)$ & $(4)$ & $(5)$ & $(6)$ \\
\hline \multicolumn{7}{|c|}{ Panel A: IV regressions for the presence of landowner associations } \\
\hline Socialist vote share in 1919 & $\begin{array}{c}0.503 \\
(0.156)\end{array}$ & $\begin{array}{c}0.473 \\
(0.155)\end{array}$ & $\begin{array}{c}0.316 \\
(0.121)\end{array}$ & $\begin{array}{l}0.318 \\
(0.120)\end{array}$ & $\begin{array}{c}0.642 \\
(0.253)\end{array}$ & $\begin{array}{c}0.680 \\
(0.257)\end{array}$ \\
\hline Socialists $\mathrm{x}$ landowner association dummy & $\begin{array}{l}-0.442 \\
(0.340)\end{array}$ & $\begin{array}{l}-0.380 \\
(0.319)\end{array}$ & $\begin{array}{c}0.825 \\
(0.486)\end{array}$ & $\begin{array}{c}0.834 \\
(0.474)\end{array}$ & $\begin{array}{c}0.934 \\
(0.494)\end{array}$ & $\begin{array}{c}0.930 \\
(0.487)\end{array}$ \\
\hline K-P F-stat & 27.37 & 25.53 & 27.37 & 25.53 & 27.37 & 25.53 \\
\hline
\end{tabular}

Panel B: IV regressions for the presence of elites (entrepreneurs and rentiers)

Socialist vote share in 1919

$\begin{array}{cccccc}0.484 & 0.458 & 0.307 & 0.295 & 0.666 & 0.670 \\ (0.156) & (0.165) & (0.116) & (0.117) & (0.268) & (0.264) \\ 13.953 & 19.041 & 15.370 & 16.860 & 3.054 & 2.467 \\ (7.939) & (9.185) & (6.195) & (7.623) & (14.681) & (16.731) \\ 16.73 & 13.41 & 16.73 & 13.41 & 16.73 & 13.41\end{array}$

Kleibergen Paap F-stat

$16.73-13.41$

16.73

16.73

13.41

Panel C: Reduced-form regressions for the presence of landowner associations

$\begin{array}{lccccccc}\text { Share of footsoldier casualties } & 0.876 & 0.803 & 0.532 & 0.507 & 1.094 & 1.109 \\ & (0.264) & (0.258) & (0.202) & (0.195) & (0.423) & (0.413) \\ \text { Casualties x landowner association dummy } & -0.032 & 0.075 & 5.222 & 5.297 & 7.081 & 7.212 \\ & (1.337) & (1.346) & (1.784) & (1.729) & (3.294) & (3.294)\end{array}$

Panel D: Reduced-form regressions for the presence of elites (entrepreneurs and rentiers)

Share of footsoldier casualties

Casualties $\mathrm{x}$ elites

Regiment/Province FE

Demographic controls

Geographic controls

Socialist share in 1913

Military controls

Agriculture controls

Urban controls

Observations

Number of clusters

$\begin{array}{cc}0.828 & 0.743 \\ (0.238) & (0.238) \\ 37.817 & 41.56 \\ (20.007) & (19.138) \\ & \\ \checkmark & \checkmark \\ \checkmark & \checkmark \\ \checkmark & \checkmark \\ \checkmark & \checkmark \\ \checkmark & \checkmark \\ & \checkmark \\ & \checkmark\end{array}$

$5,775 \quad 5,775$
0.522

(0.203)

37.447

(17.774)
0.475

(0.192)

1.147

$(0.435)$

$35.112 \quad 18.702$

(17.375)
1.114

(0.403)

14.784

(27.126)

Notes: 2SLS (Panels A and B) and reduced-form regressions (Panel C and D) of the heterogeneous effect of the Socialist vote share in 1919 on Fascism in the presence of landowners' associations (Panel A and C) and the share of elites (Panel B and D). The endogenous variables are Socialist vote share in 1919 and its interaction with the measure of elite organization. Excluded instruments are the count of WWI footsoldier casualties from a municipality divided by the total male population over the age of six in 1911 and its interaction with the elite variables. The left had side variables are the Fascist vote share in 1924 (columns 1 and 2), the Fascist violence (episodes per 1000 inhabitants) in $1920-22$ (columns 3 and 4) and the presence of local Fascist branches in the Fall of 1921 (columns 5 and 6). The two specifications correspond to those from columns 4 and 6 in Table 1. Column 4 includes regiment and province fixed effects and demographic controls (quartic in log population and share of population below the age of six in 1911), geographic controls (log area, elevation of the main center, and maximum elevation), the Socialist vote share in 1913, and military controls (veterans from classes 1874-1895 and from classes 1896-1900 as well as dummies for any casualties of special assault corps from the municipality, any casualties in the highest-mortality battles, and any casualties among volunteers from the municipality). Column 6 additionally includes agricultural controls (share of day laborers, share of sharecroppers and a dummy for the presence of local agrarian associations) and urban controls (industry workers and industrial firms over male population in 1911, literacy rate in 1911, the share of entrepreneurs and rentiers, and the share of the bourgeoisie). Standard errors clustered at the district level are in parentheses. 
Table 9: Results with alternative instruments: Spanish flu excess mortality in 1918 and relative rainfall in 1918-19

$\begin{array}{ccccccc}\text { Dep variable: } & \text { Socialist vote share } & \text { Fascist vote share } & \text { Fascist violence } & \text { Fascist branches } \\ \text { in } 1919 & \text { in } 1924 & \text { in } 1920-2 & \text { in } 1921 \\ (1) & (2) & (3) & (4) & \text { (5) } & \text { (6) } & \text { (7) }\end{array}$

Panel A: Using excess mortality in 1918 as instrument

$\begin{array}{lccccccccc}\text { Excess mortality in 1918 } & \begin{array}{c}0.093 \\ (0.028)\end{array} & \begin{array}{c}0.097 \\ (0.027)\end{array} & & & & & & \\ & & & 0.599 & 0.738 & 0.054 & -0.046 & 1.567 & 0.908 \\ \text { Socialist vote share in 1919 } & & & (0.397) & (0.428) & (0.214) & (0.195) & (0.834) & (0.756) \\ & 10.78 & 12.84 & & & & & & \\ \text { 1st stage F-stat } & 207 & 207 & 207 & 207 & 231 & 231 & 231 & 231 \\ \text { Observations } & 159 & 159 & 159 & 159 & 178 & 178 & 178 & 178 \\ \text { Number of clusters } & 159\end{array}$

Panel B: Using rainfall in winter and spring 1818-1919 as instrument

\begin{tabular}{lcccccccc}
$\begin{array}{l}\text { Relative winter-spring } \\
\text { rainfall in 1918-9 }\end{array}$ & -0.154 & -0.148 & & & & & & \\
Socialist vote share in 1919 & $(0.056)$ & $(0.057)$ & & & & & & \\
& & & 0.711 & 0.784 & -0.016 & 0.044 & -0.259 & -0.217 \\
& & & $(0.372)$ & $(0.388)$ & $(0.134)$ & $(0.153)$ & $(0.274)$ & $(0.281)$ \\
Rainfall variance & $\checkmark$ & $\checkmark$ & $\checkmark$ & $\checkmark$ & $\checkmark$ & $\checkmark$ & $\checkmark$ & $\checkmark$ \\
1st stage F-stat & 6.957 & 6.209 & & & & & & \\
Observations & 5,500 & 5,500 & 5,500 & 5,500 & 5,500 & 5,500 & 5,500 & 5,500 \\
Number of district clusters & 174 & 174 & 174 & 174 & 174 & 174 & 174 & 174 \\
Number of station clusters & 427 & 427 & 427 & 427 & 427 & 427 & 427 & 427 \\
& & & & & & & & \\
Regiment/Province FE & $\checkmark$ & $\checkmark$ & $\checkmark$ & $\checkmark$ & $\checkmark$ & $\checkmark$ & $\checkmark$ & $\checkmark$ \\
Demographic controls & $\checkmark$ & $\checkmark$ & $\checkmark$ & $\checkmark$ & $\checkmark$ & $\checkmark$ & $\checkmark$ & $\checkmark$ \\
Geographic controls & $\checkmark$ & $\checkmark$ & $\checkmark$ & $\checkmark$ & $\checkmark$ & $\checkmark$ & $\checkmark$ & $\checkmark$ \\
Socialist share in 1913 & $\checkmark$ & $\checkmark$ & $\checkmark$ & $\checkmark$ & $\checkmark$ & $\checkmark$ & $\checkmark$ & $\checkmark$ \\
Military controls & $\checkmark$ & $\checkmark$ & $\checkmark$ & $\checkmark$ & $\checkmark$ & $\checkmark$ & $\checkmark$ & $\checkmark$ \\
Agriculture controls & & $\checkmark$ & & $\checkmark$ & & $\checkmark$ & & $\checkmark$ \\
Urban controls & & $\checkmark$ & & $\checkmark$ & & $\checkmark$ & & $\checkmark$ \\
\hline
\end{tabular}

Notes: 2SLS regressions of the Fascist vote share in 1924 (columns 3 and 4), Fascist violence between 1920 and 1922 (columns 5 and 6) and Fascist branches in 1921 (columns 7 and 8) on the Socialist vote share in 1919. First stage results are reported in columns 1 and 2. In Panel A the excluded instrument is excess mortality due to the Spanish Flu in 1918. Excess mortality is defined as the excess mortality in 1918 from the pre-war mortality computed between 1911 and 1914. In Panel B the excluded instrument is the relative rainfall in winter-spring 1918-1919 (from December 1918 to May 1919). Relative rainfall is measured at weather station level, using the average for the winter-spring months for the years 1915-1979 as denominator, and then interpolated at municipality level using the inverse of the distances as weights with a cutoff of $30 \mathrm{~km}$. The relative rainfall measure is then capped at 1 in order to consider only negative deviations from the long term average. The two specifications correspond to those from columns 4 and 6 in Table 1 . Column 4 includes regiment and province fixed effects and demographic controls (quartic in log population and share of population below the age of six in 1911), geographic controls (log area, elevation of the main center, and maximum elevation), the Socialist vote share in 1913, and military controls (veterans from classes 1874-1895 and from classes 1896-1900 as well as dummies for any casualties of special assault corps from the municipality, any casualties in the highest-mortality battles, and any casualties among volunteers from the municipality). Column 6 additionally includes agricultural controls (share of day laborers, share of sharecroppers and a dummy for the presence of local agrarian associations) and urban controls (industry workers and industrial firms over male population in 1911, literacy rate in 1911, the share of entrepreneurs and rentiers, and the share of the bourgeoisie). We report in parentheses standard errors clustered at the district level (Panel A) and clustered over district and closest weather station (Panel B). 
Table 10: 2SLS estimates of the effect of Fascist vote share in 1924 on Jewish deportations 1943-45

(1)

(2)

(3)

(4)

(5)

(6)

Panel A: Jews deportation dummy (1943-45) - IV

Fascist vote share in 1924

$\begin{array}{cccccc}0.884 & 0.810 & 0.817 & 0.805 & 0.866 & 0.862 \\ (0.462) & (0.419) & (0.416) & (0.382) & (0.427) & (0.437)\end{array}$

Panel B: Deportations over Jewish population (capped at 1) - IV

$\begin{array}{lcccccc}\text { Fascist vote share in } 1924 & 0.886 & 0.817 & 0.815 & 0.787 & 0.854 & 0.844 \\ & (0.412) & (0.362) & (0.357) & (0.316) & (0.359) & (0.367)\end{array}$

Panel C: Deportations over Jewish population (cap at 1 no camps) - IV

Fascist vote share in 1924

$\begin{array}{cccccc}0.783 & 0.727 & 0.721 & 0.694 & 0.751 & 0.744 \\ (0.382) & (0.341) & (0.334) & (0.295) & (0.335) & (0.341)\end{array}$

Regiment/Province FE

Demographic controls

Share of jewish pop in 1911

Geographic controls

Socialist share in 1913

Military controls

Agriculture controls

Urban controls

\begin{tabular}{lcccccc} 
Observations & 5,775 & 5,775 & 5,775 & 5,775 & 5,775 & 5,775 \\
Number of clusters & 181 & 181 & 181 & 181 & 181 & 181 \\
1st Stage F-stat & 6.467 & 9.095 & 9.714 & 11.13 & 9.510 & 9.649 \\
\hline
\end{tabular}

Notes: 2SLS regressions of: a dummy for the occurrence of Jews deportation in 1943-45 (Panel A); the number of deported Jews in 1943-45 over 1911 Jewish population, capped at 1 (Panel B); the number of deported Jews in 1943-45 over 1911 Jewish population, capped at 1 and excluding 39 municipalities with concentration camps (Panel C) on the Fascist vote share in 1924. Excluded instrument is the count of WWI footsoldier casualties from a municipality divided by the total male population over the age of six in 1911 . Column 1 includes regiment and province fixed effects and demographic controls (quartic in log population and share of population below the age of six in 1911). Column 2 additionally includes geographic controls (log area, elevation of the main center, and maximum elevation). Column 3 adds Socialist vote share in 1913. Column 4 adds military controls (veterans from classes 1874-1895 and from classes 18961900 as well as dummies for any casualties of special assault corps from the municipality, any casualties in the highest-mortality battles, and any casualties among volunteers from the municipality). Column 5 additionally includes agricultural controls (share of day laborers, share of sharecroppers and a dummy for the presence of local agrarian associations). Finally column 6 adds urban controls (industry workers and industrial firms over male population in 1911, literacy rate in 1911, the share of entrepreneurs and rentiers, and the share of the bourgeoisie). Standard errors clustered at the district level are in parentheses. 
Table 11: 2SLS estimates of the effect of Fascist vote share in 1924 on post-WWII party vote shares

\begin{tabular}{|c|c|c|c|c|c|c|c|c|c|c|}
\hline Dep variable: Votes & $\begin{array}{r}\text { ares of } \\
(1)\end{array}$ & (2) & (3) & (4) & (5) & $(6)$ & (7) & (8) & (9) & $(10)$ \\
\hline \multicolumn{11}{|l|}{ Panel A: } \\
\hline Left & $\begin{array}{c}0.443 \\
(0.191)\end{array}$ & $\begin{array}{c}1.081 \\
(0.420)\end{array}$ & $\begin{array}{c}0.791 \\
(0.338)\end{array}$ & $\begin{array}{c}0.839 \\
(0.388)\end{array}$ & $\begin{array}{c}0.654 \\
(0.320)\end{array}$ & $\begin{array}{c}0.563 \\
(0.282)\end{array}$ & $\begin{array}{c}0.400 \\
(0.233)\end{array}$ & $\begin{array}{c}0.495 \\
(0.266)\end{array}$ & $\begin{array}{c}0.651 \\
(0.310)\end{array}$ & $\begin{array}{c}0.543 \\
(0.269)\end{array}$ \\
\hline Centre-right & $\begin{array}{l}-0.434 \\
(0.182)\end{array}$ & $\begin{array}{l}-0.778 \\
(0.327)\end{array}$ & $\begin{array}{l}-0.616 \\
(0.311)\end{array}$ & $\begin{array}{l}-0.742 \\
(0.327)\end{array}$ & $\begin{array}{l}-0.647 \\
(0.268)\end{array}$ & $\begin{array}{l}-0.569 \\
(0.272)\end{array}$ & $\begin{array}{l}-0.630 \\
(0.277)\end{array}$ & $\begin{array}{l}-0.615 \\
(0.288)\end{array}$ & $\begin{array}{l}-0.606 \\
(0.285)\end{array}$ & $\begin{array}{l}-0.578 \\
(0.270)\end{array}$ \\
\hline Extreme left & $\begin{array}{c}0.038 \\
(0.020)\end{array}$ & $\begin{array}{c}0.002 \\
(0.002)\end{array}$ & $\begin{array}{c}0.003 \\
(0.004)\end{array}$ & & & & $\begin{array}{l}0.128 \\
(0.066)\end{array}$ & $\begin{array}{c}0.081 \\
(0.049)\end{array}$ & $\begin{array}{l}-0.004 \\
(0.016)\end{array}$ & $\begin{array}{c}0.037 \\
(0.015)\end{array}$ \\
\hline Extreme right & $\begin{array}{c}0.023 \\
(0.020)\end{array}$ & & $\begin{array}{c}0.021 \\
(0.039)\end{array}$ & $\begin{array}{c}0.048 \\
(0.053)\end{array}$ & $\begin{array}{c}0.040 \\
(0.032)\end{array}$ & $\begin{array}{c}0.023 \\
(0.036)\end{array}$ & $\begin{array}{c}0.046 \\
(0.033)\end{array}$ & $\begin{array}{c}0.080 \\
(0.046)\end{array}$ & $\begin{array}{c}0.012 \\
(0.036)\end{array}$ & $\begin{array}{c}0.035 \\
(0.035)\end{array}$ \\
\hline Election(s): & $1946-2018$ & 1946 & 1948 & 1953 & 1958 & 1963 & 1968 & 1972 & 1976 & 1979 \\
\hline Observations & 109,725 & 5,775 & 5,775 & 5,775 & 5,775 & 5,775 & 5,775 & 5,775 & 5,775 & 5,775 \\
\hline Number of clusters & 5775 & 181 & 181 & 181 & 181 & 181 & 181 & 181 & 181 & 181 \\
\hline 1st Stage F-stat & 9.871 & 9.668 & 9.668 & 9.668 & 9.668 & 9.668 & 9.668 & 9.668 & 9.668 & 9.668 \\
\hline \multicolumn{11}{|l|}{ Panel B: } \\
\hline Left & $\begin{array}{c}0.460 \\
(0.241)\end{array}$ & $\begin{array}{c}0.475 \\
(0.240)\end{array}$ & $\begin{array}{c}0.227 \\
(0.171)\end{array}$ & $\begin{array}{c}0.209 \\
(0.116)\end{array}$ & $\begin{array}{c}0.101 \\
(0.100)\end{array}$ & $\begin{array}{c}0.164 \\
(0.120)\end{array}$ & $\begin{array}{c}0.267 \\
(0.148)\end{array}$ & $\begin{array}{c}0.093 \\
(0.056)\end{array}$ & $\begin{array}{c}0.200 \\
(0.127)\end{array}$ & $\begin{array}{c}0.210 \\
(0.122)\end{array}$ \\
\hline Centre-right & $\begin{array}{l}-0.408 \\
(0.229)\end{array}$ & $\begin{array}{l}-0.516 \\
(0.236)\end{array}$ & $\begin{array}{l}-0.441 \\
(0.226)\end{array}$ & $\begin{array}{l}-0.304 \\
(0.138)\end{array}$ & $\begin{array}{l}-0.046 \\
(0.099)\end{array}$ & $\begin{array}{l}-0.171 \\
(0.124)\end{array}$ & $\begin{array}{l}-0.187 \\
(0.119)\end{array}$ & $\begin{array}{l}-0.100 \\
(0.058)\end{array}$ & $\begin{array}{l}-0.213 \\
(0.151)\end{array}$ & $\begin{array}{l}-0.079 \\
(0.086)\end{array}$ \\
\hline Extreme left & $\begin{array}{l}-0.022 \\
(0.014)\end{array}$ & $\begin{array}{l}-0.018 \\
(0.021)\end{array}$ & $\begin{array}{c}0.077 \\
(0.054)\end{array}$ & $\begin{array}{c}0.078 \\
(0.048)\end{array}$ & $\begin{array}{c}0.100 \\
(0.060)\end{array}$ & $\begin{array}{c}0.043 \\
(0.045)\end{array}$ & $\begin{array}{c}0.101 \\
(0.056)\end{array}$ & $\begin{array}{c}0.006 \\
(0.004)\end{array}$ & $\begin{array}{c}0.001 \\
(0.003)\end{array}$ & $\begin{array}{l}-0.003 \\
(0.014)\end{array}$ \\
\hline Extreme right & $\begin{array}{c}0.045 \\
(0.046)\end{array}$ & $\begin{array}{c}0.007 \\
(0.045)\end{array}$ & $\begin{array}{c}0.013 \\
(0.037)\end{array}$ & & $\begin{array}{c}0.006 \\
(0.012)\end{array}$ & $\begin{array}{l}-0.000 \\
(0.010)\end{array}$ & $\begin{array}{l}-0.015 \\
(0.017)\end{array}$ & $\begin{array}{c}0.013 \\
(0.008)\end{array}$ & $\begin{array}{c}0.005 \\
(0.014)\end{array}$ & $\begin{array}{c}0.007 \\
(0.012)\end{array}$ \\
\hline Election: & 1983 & 1987 & 1992 & 1994 & 1996 & 2001 & 2006 & 2008 & 2013 & 2018 \\
\hline Observations & 5,775 & 5,775 & 5,775 & 5,775 & 5,775 & 5,775 & 5,775 & 5,775 & 5,775 & 5,775 \\
\hline Number of clusters & 181 & 181 & 181 & 181 & 181 & 181 & 181 & 181 & 181 & 181 \\
\hline 1st Stage F-stat & 9.668 & 9.668 & 9.668 & 9.668 & 9.668 & 9.668 & 9.668 & 9.668 & 9.668 & 9.668 \\
\hline Full set of controls & $\checkmark$ & $\checkmark$ & $\checkmark$ & $\checkmark$ & $\checkmark$ & $\checkmark$ & $\checkmark$ & $\checkmark$ & $\checkmark$ & $\checkmark$ \\
\hline
\end{tabular}

Notes: 2SLS regressions of the vote shares of post-WWII parties for the period 1946-2018 on Fascist vote share in 1924. The left column identifies the party whose vote share is used as dependent variable in the regressions in each row. The heading Election identifies the election(s) included in the sample. The excluded instrument is the count of footsoldier casualties from a municipality divided by the total male population over the age of six in 1911. All specifications include our full set of controls. We include regiment and province fixed effects and demographic controls (quartic in log population and share of population below the age of six in 1911), geographic controls (log area, elevation of the main center, and maximum elevation), the Socialist vote share in 1913, military controls (veterans from classes 1874-1895 and from classes 1896-1900, dummies for any casualties of special assault corps from the municipality, any casualties in the highest-mortality battles, and any casualties among volunteers from the municipality), agricultural controls (share of day laborers, share of sharecroppers and a dummy for the presence of local agrarian associations) and urban controls (industry workers and industrial firms over male population in 1911, literacy rate in 1911, the share of entrepreneurs and rentiers, and the share of the bourgeoisie). Standard errors clustered at the district level are in parenthesis. Column 1 of Panel A reports a pooled 2SLS regression for the period 1946-2018 where all controls are interacted with election dummies and standard errors are clustered at the municipality level. 


\section{A Online Appendix (Not For Publication)}

Figure A1: Example of newspaper source - Rinascita, April 11, 1924

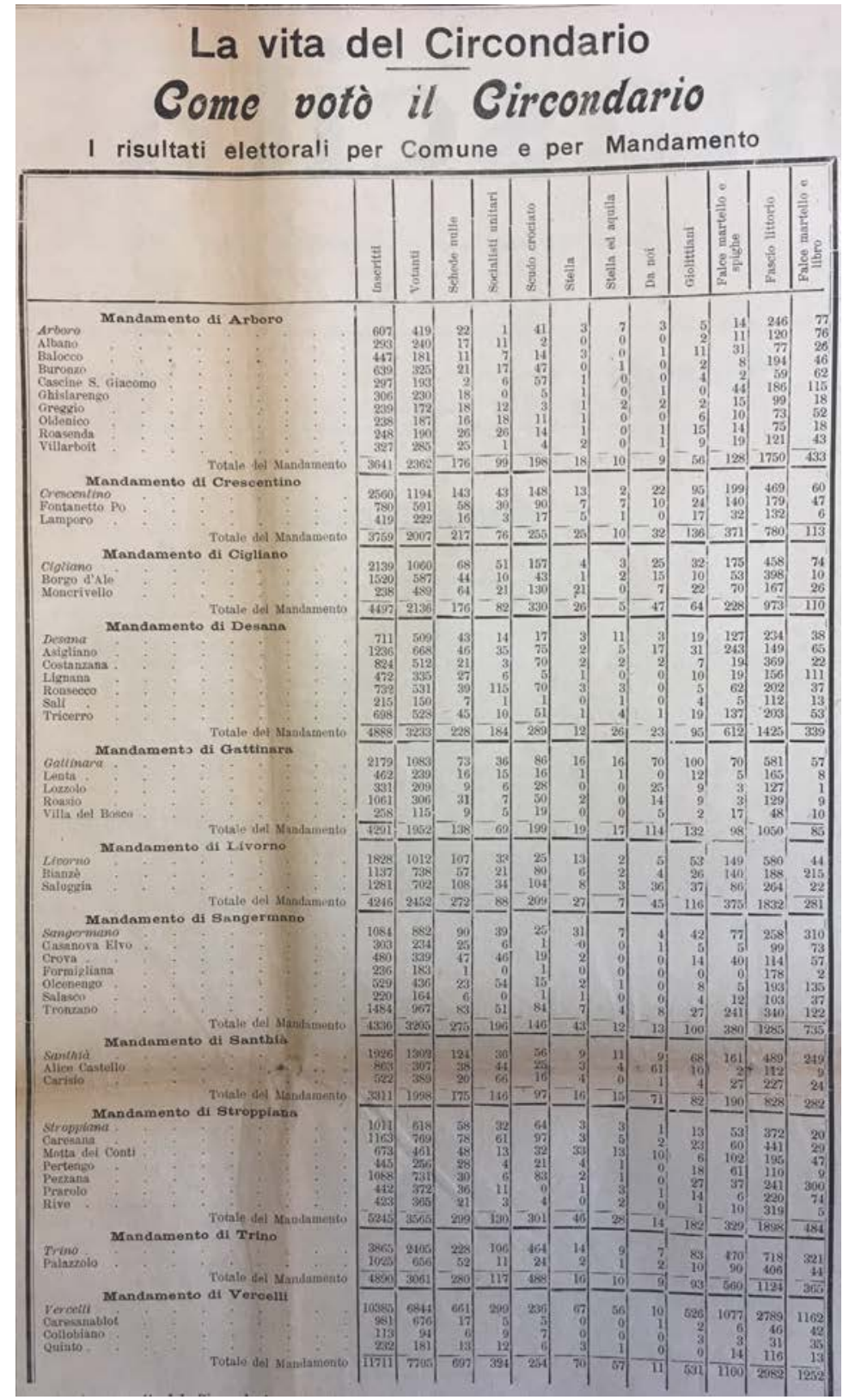


Figure A2: Examples of archival sources

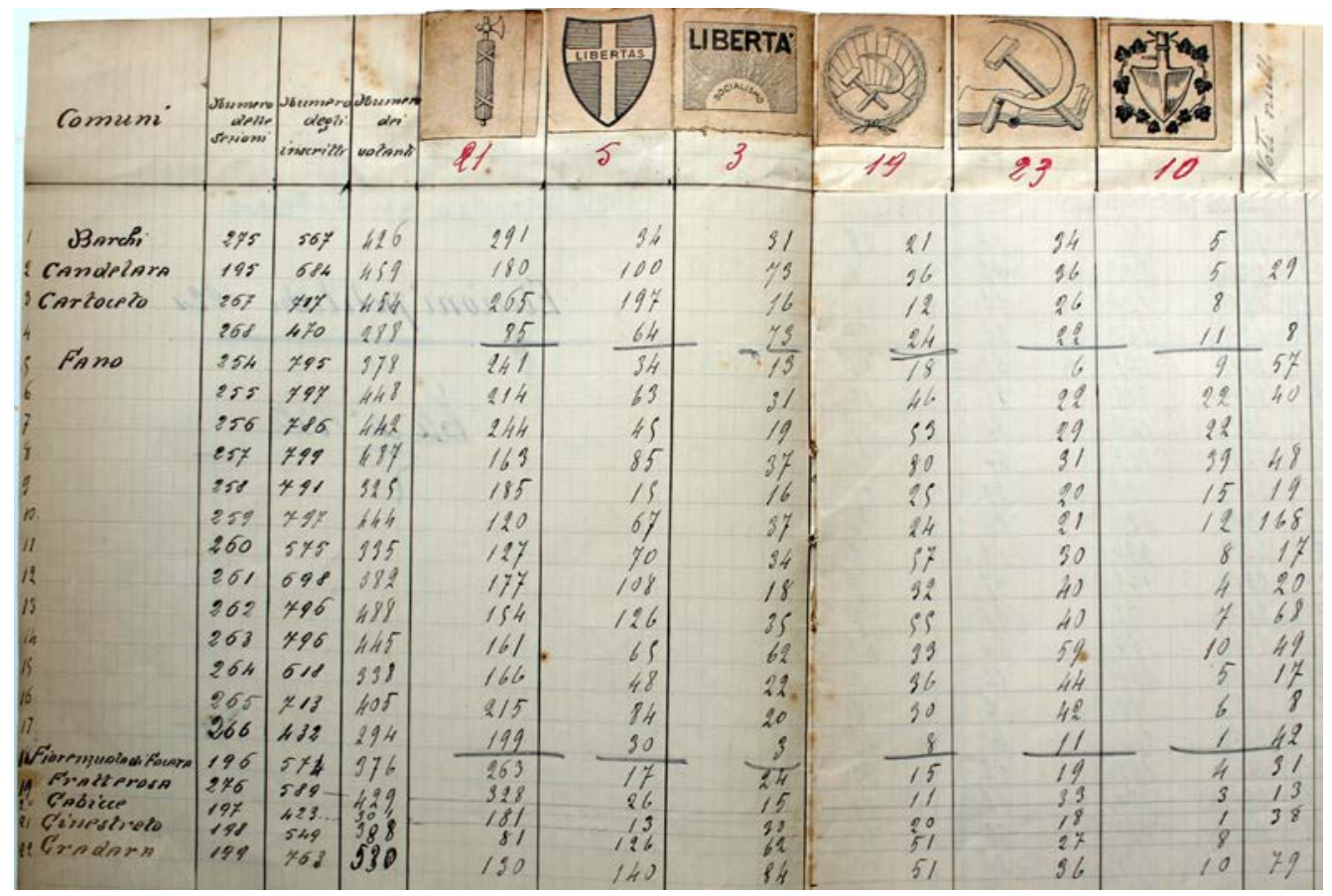

(a) Summary list from Pesaro-Urbino State Archive

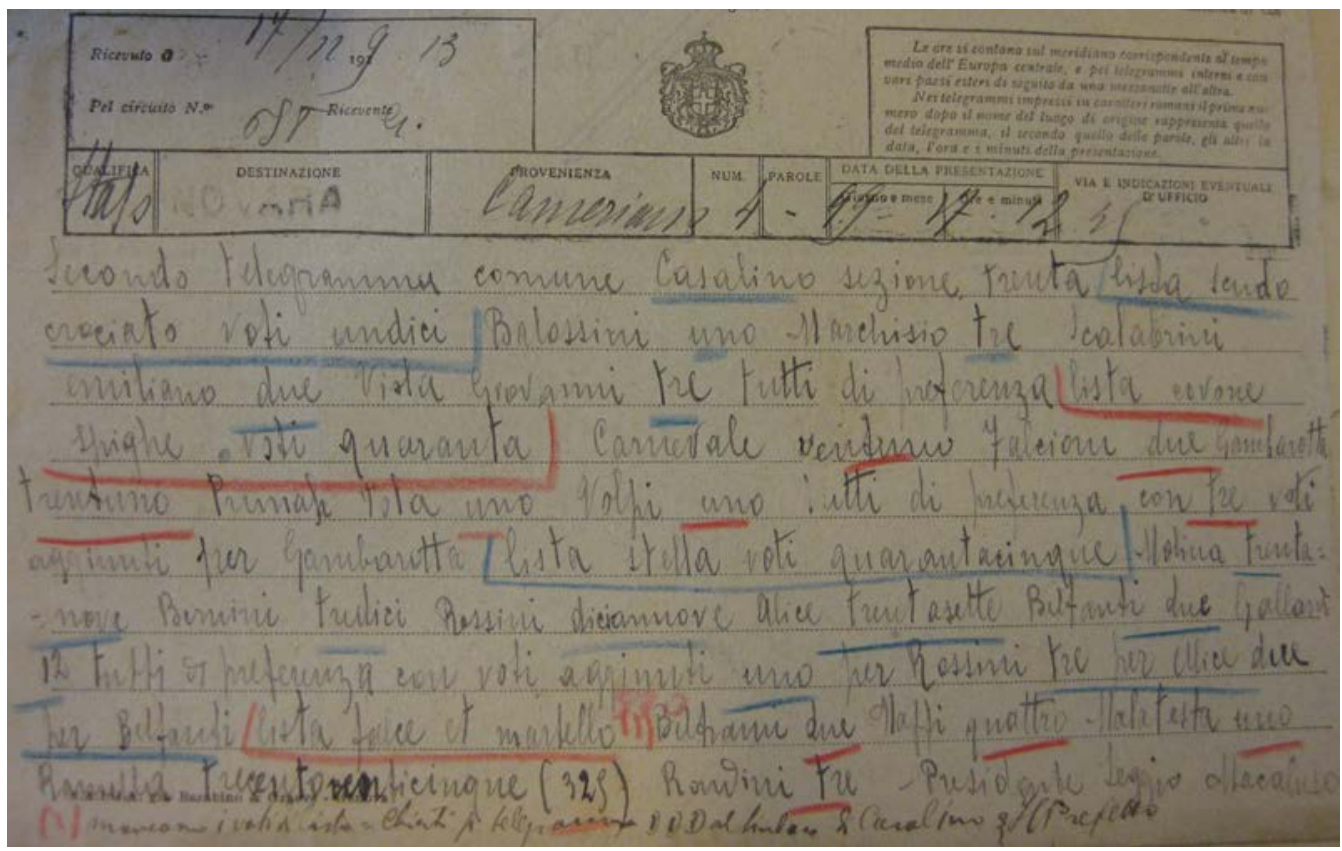

(b) Telegraphic communication from Novara State Archive 
Figure A3: Relative rainfall in winter-spring 1918-9

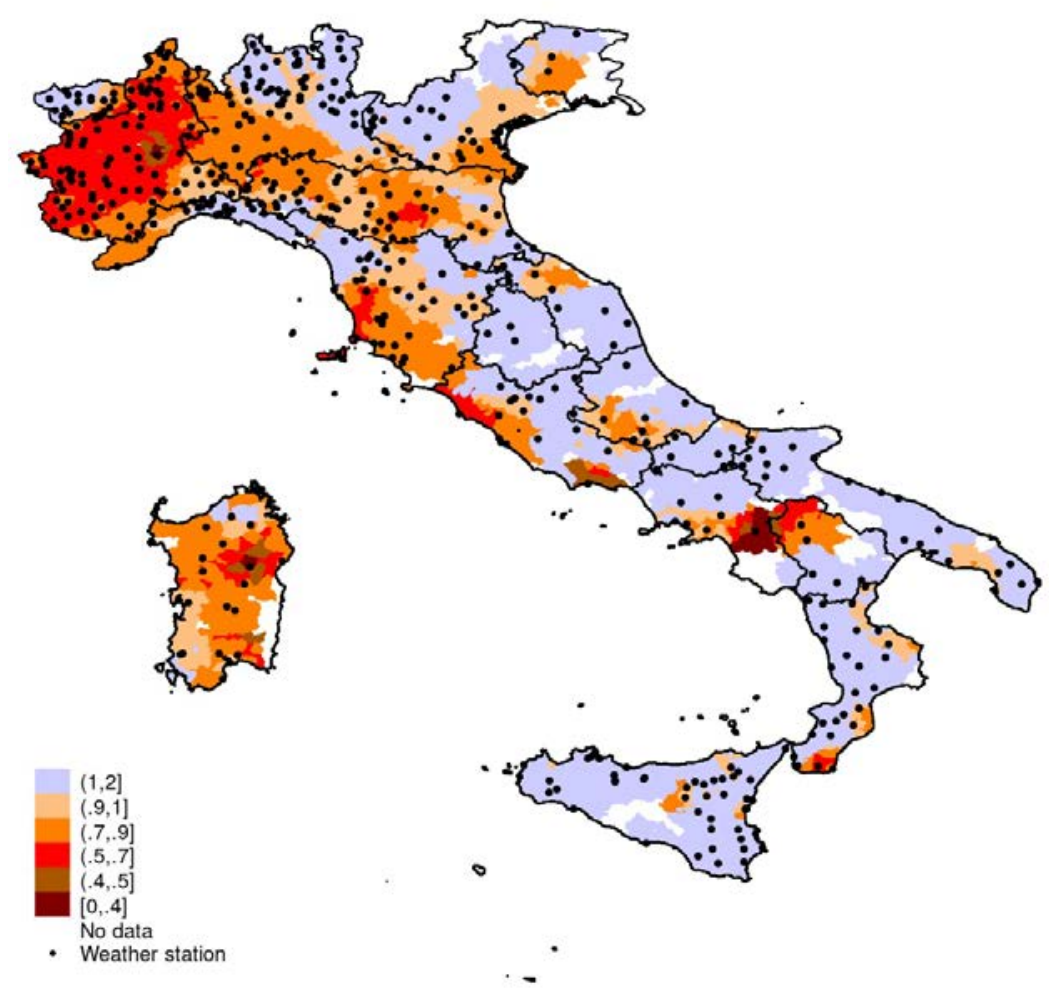

Notes: Relative rainfall in winter-spring 1918-9 using data from 427 weather stations gathered from the Hydrographic Bulletins (1915-1979) for the 16 Italian hydrographic compartments. Relative rainfall is measured at the weather station level (aggregating rainfall from December 1918 to May 1919), using the average for the winter-spring months for the years 1915-1979 as denominator, and then interpolated at the municipality level using the inverse of the distances as weights with a cutoff of $30 \mathrm{~km}$. The blue shading identifies areas with more abundant rainfall in winter-spring 1918-9 as compared to their usual rainfall pattern. Orange, red, and brown shadings identify progressively lower rainfall in winter-spring 1918-9 as compared to their usual rainfall pattern. Black dots denote the location of weather stations. 
Table A1: Descriptive statistics

\begin{tabular}{|c|c|c|c|c|c|}
\hline Variable & Obs & Mean & Std. Dev. & Min & Max \\
\hline \multicolumn{6}{|l|}{ Dependent variables: } \\
\hline Fascist vote share in 1924 & 5,775 & 0.619 & 0.257 & 0 & 1 \\
\hline Fascist violence in 1920-2 & 5,775 & .042 & 0.164 & 0 & 2.225 \\
\hline Fascist local branches in Autumn 1921 & 5,775 & 0.145 & 0.352 & 0 & 1 \\
\hline Agrarian Strikes in 1920 & 5,775 & 0.303 & 0.600 & 0 & 4 \\
\hline Jews deportation dummy (1943-45) & 5,775 & 0.070 & 0.255 & 0 & 1 \\
\hline Deportations over Jewish population (capped at 1) & 5,775 & 0.050 & 0.21 & 0 & 1 \\
\hline Deportations over Jewish population (cap at 1 no camps) & 5,736 & 0.044 & 0.197 & 0 & 1 \\
\hline Left vote share (1946-2018) & 109,725 & 0.224 & 0.134 & 0 & 0.880 \\
\hline Centre-right vote share (1946-2018) & 109,725 & 0.363 & 0.179 & 0 & 0.992 \\
\hline Extreme right vote share (1946-2018) & 98,175 & 0.026 & 0.029 & 0 & 0.729 \\
\hline Extreme left vote share (1946-2018) & 92,400 & 0.029 & 0.032 & 0 & 0.632 \\
\hline \multicolumn{6}{|l|}{ Main excluded instruments: } \\
\hline Foot-soldier casualties over male pop above 6 & 5,775 & 0.032 & 0.016 & 0 & 0.385 \\
\hline Excess mortality in 1918 & 231 & 0.892 & 0.387 & -0.191 & 3.482 \\
\hline Relative winter-spring rainfall 1918-9 & 5,500 & 0.849 & 0.166 & 0.213 & 1 \\
\hline \multicolumn{6}{|l|}{ Socialist support: } \\
\hline Socialist vote share in 1913 & 5,775 & 0.160 & 0.223 & 0 & 1 \\
\hline Socialist vote share in 1919 & 5,775 & 0.316 & 0.271 & 0 & 1 \\
\hline Socialist (+ Communist) vote share in 1921 & 5,083 & 0.258 & 0.227 & 0 & 1 \\
\hline Socialist (+ Communist) vote share in 1924 & 5,751 & 0.152 & 0.153 & 0 & 0.866 \\
\hline \multicolumn{6}{|l|}{ Demographic controls: } \\
\hline Share of below 6 population in 1911 & 5,775 & 0.158 & 0.033 & 0.054 & 0.928 \\
\hline \multicolumn{6}{|l|}{ Geographic controls: } \\
\hline Elevation of the major centre & 5,775 & 318.195 & 280.476 & 1 & 1816 \\
\hline Maximum elevation & 5,775 & 836.126 & 840.759 & 1 & 4810 \\
\hline \multicolumn{6}{|l|}{ Military controls: } \\
\hline Dummy for casualties in assault troops & 5,775 & 0.238 & 0.426 & 0 & 1 \\
\hline Dummy for casualties in voluntary troops & 5,775 & 0.013 & 0.112 & 0 & 1 \\
\hline Dummy for casualties in deadly battles & 5,775 & 0.960 & 0.195 & 0 & 1 \\
\hline Veterans (classes 1874-1895) over male pop above 6 in 1911 & 5,775 & 0.234 & 0.057 & 0.099 & 0.406 \\
\hline Veterans (classes 1896-1900) over male pop above 6 in 1911 & 5,775 & 0.132 & 0.023 & 0.069 & 0.204 \\
\hline \multicolumn{6}{|l|}{ Agriculture controls: } \\
\hline Share of day labourers in 1921 & 5,775 & 0.214 & 0.118 & 0.010 & 0.678 \\
\hline Share of share-croppers in 1921 & 5,775 & 0.052 & 0.071 & 0 & 0.421 \\
\hline Landowner association dummy & 5,775 & 0.050 & 0.218 & 0 & 1 \\
\hline \multicolumn{6}{|l|}{ Urban controls: } \\
\hline Industrial workers over male population in 1911 & 5,775 & 0.116 & 0.216 & 0 & 6.028 \\
\hline Industry firms over male population in 1911 & 5,775 & 0.012 & 0.011 & 0 & 0.138 \\
\hline Male literacy in 1911 & 5,775 & 0.751 & 0.198 & 0.101 & 1 \\
\hline Share of elites (entrepreneurs and rentiers) in 1921 & 5,775 & 0.026 & 0.012 & 0 & 0.088 \\
\hline Share of bourgeoisie in 1921 & 5,775 & 0.085 & 0.032 & 0.028 & 0.240 \\
\hline
\end{tabular}


Table A2: 2SLS estimates of the effects of Socialist vote share in 1919 on measures of Fascist support using spatially-corrected (Conley) standard errors

\begin{tabular}{|c|c|c|c|c|c|c|c|c|}
\hline \multirow[t]{2}{*}{ Dep variable: } & \multicolumn{2}{|c|}{$\begin{array}{c}\text { Socialist vote share } \\
\text { in } 1919\end{array}$} & \multicolumn{2}{|c|}{$\begin{array}{c}\text { Fascist vote share } \\
\text { in } 1924\end{array}$} & \multicolumn{2}{|c|}{$\begin{array}{l}\text { Fascist branches } \\
\quad \text { in } 1921\end{array}$} & \multicolumn{2}{|c|}{$\begin{array}{l}\text { Fascist violence } \\
\text { in } 1920-2\end{array}$} \\
\hline & (1) & (2) & (3) & (4) & $(5)$ & (6) & $(7)$ & $(8)$ \\
\hline Share of footsoldier casualties & $\begin{array}{l}1.752 \\
(0.252)\end{array}$ & $\begin{array}{c}1.689 \\
(0.248)\end{array}$ & & & & & & \\
\hline Socialist vote share in 1919 & & & $\begin{array}{c}0.504 \\
(0.131)\end{array}$ & $\begin{array}{c}0.476 \\
(0.139)\end{array}$ & $\begin{array}{c}0.329 \\
(0.142)\end{array}$ & $\begin{array}{c}0.312 \\
(0.126)\end{array}$ & $\begin{array}{c}0.670 \\
(0.275)\end{array}$ & $\begin{array}{c}0.672 \\
(0.227)\end{array}$ \\
\hline Regiment/Province FE & $\checkmark$ & $\checkmark$ & $\checkmark$ & $\checkmark$ & $\checkmark$ & $\checkmark$ & $\checkmark$ & $\checkmark$ \\
\hline Demographic controls & $\checkmark$ & $\checkmark$ & $\checkmark$ & $\checkmark$ & $\checkmark$ & $\checkmark$ & $\checkmark$ & $\checkmark$ \\
\hline Geographic controls & $\checkmark$ & $\checkmark$ & $\checkmark$ & $\checkmark$ & $\checkmark$ & $\checkmark$ & $\checkmark$ & $\checkmark$ \\
\hline Socialist share in 1913 & $\checkmark$ & $\checkmark$ & $\checkmark$ & $\checkmark$ & $\checkmark$ & $\checkmark$ & $\checkmark$ & $\checkmark$ \\
\hline Military controls & $\checkmark$ & $\checkmark$ & $\checkmark$ & $\checkmark$ & $\checkmark$ & $\checkmark$ & $\checkmark$ & $\checkmark$ \\
\hline Agriculture controls & & $\checkmark$ & & $\checkmark$ & & $\checkmark$ & & $\checkmark$ \\
\hline Urban controls & & $\checkmark$ & & $\checkmark$ & & $\checkmark$ & & $\checkmark$ \\
\hline 1st stage F-stat & 48.34 & 46.38 & & & & & & \\
\hline Observations & 5,775 & 5,775 & 5,775 & 5,775 & 5,775 & 5,775 & 5,775 & 5,775 \\
\hline
\end{tabular}

Notes: 2SLS regressions of the Fascist vote share in 1924 (columns 3 and 4), Fascist branches in 1921 (columns 5 and 6) and Fascist violence between 1920 and 1922 (columns 7 and 8) on the Socialist vote share in 1919. First stage results are reported in columns 1 and 2. The excluded instrument is the count of footsoldier casualties from a municipality divided by the total male population over the age of six in 1911. The two specifications correspond to those from columns 4 and 6 in Table 1. Column 4 includes regiment and province fixed effects and demographic controls (quartic in log population and share of population below the age of six in 1911), geographic controls (log area, elevation of the main center, and maximum elevation), the Socialist vote share in 1913, and military controls (veterans from classes 1874-1895 and from classes 1896-1900 as well as dummies for any casualties of special assault corps from the municipality, any casualties in the highest-mortality battles, and any casualties among volunteers from the municipality). Column 6 additionally includes agricultural controls (share of day laborers, share of sharecroppers and a dummy for the presence of local agrarian associations) and urban controls (industry workers and industrial firms over male population in 1911, literacy rate in 1911, the share of entrepreneurs and rentiers, and the share of the bourgeoisie). Spatially-corrected (Conley) standard errors with cutoffs at 1.5 degrees for both latitude and longitude are in parentheses. 
Table A3: First-stage estimates using alternative definitions of our casualties instrument

\begin{tabular}{lcccccc}
\hline Dep variable: Socialist vote share in 1919 & & & & & \\
& $(1)$ & $(2)$ & $(3)$ & $(4)$ & $(5)$ & $(6)$ \\
\hline Casualties among reservist \& & 1.622 & 1.563 & & & & \\
drafted footsoldiers & $(0.213)$ & $(0.214)$ & & & & \\
Casualties among drafted & & & 2.002 & 1.860 & & \\
footsoldiers & & & $(0.303)$ & $(0.303)$ & & \\
Casualties among & & & & & & \\
all soldiers & & & & & 1.250 & 1.210 \\
& & & & & & \\
Regiment/Province FE & $\checkmark$ & $\checkmark$ & $\checkmark$ & $\checkmark$ & $\checkmark$ & $\checkmark$ \\
Demographic controls & $\checkmark$ & $\checkmark$ & $\checkmark$ & $\checkmark$ & $\checkmark$ & $\checkmark$ \\
Geographic controls & $\checkmark$ & $\checkmark$ & $\checkmark$ & $\checkmark$ & $\checkmark$ & $\checkmark$ \\
Socialist share in 1913 & $\checkmark$ & $\checkmark$ & $\checkmark$ & $\checkmark$ & $\checkmark$ & $\checkmark$ \\
Military controls & $\checkmark$ & $\checkmark$ & $\checkmark$ & $\checkmark$ & $\checkmark$ & $\checkmark$ \\
Agriculture controls & & $\checkmark$ & & $\checkmark$ & & $\checkmark$ \\
Urban controls & & $\checkmark$ & & $\checkmark$ & & $\checkmark$ \\
Observations & & & & & & \\
R-squared & 5,775 & 5,775 & 5,775 & 5,775 & 5,775 & 5,775 \\
Number of clusters & 0.693 & 0.696 & 0.691 & 0.694 & 0.693 & 0.696 \\
F-stat & 181 & 181 & 181 & 181 & 181 & 181 \\
\hline
\end{tabular}

Notes: First-stage regression using alternative measures of casualties. In columns 1 and 2 excluded instrument is defined using the number of casualties from men drafted and reservists. Columns 3 and 4 use only the number of casualties from men drafted to construct the excluded instrument while columns 5 and 6 use casualties from all soldiers. All versions of the instruments are computed in shares, dividing the number of casualties with the total male population over six years old in 1911. The two specifications correspond to those from columns 4 and 6 in Table 1. Column 4 includes regiment and province fixed effects and demographic controls (quartic in log population and share of population below the age of six in 1911), geographic controls (log area, elevation of the main center, and maximum elevation), the Socialist vote share in 1913, and military controls (veterans from classes 1874-1895 and from classes 1896-1900 as well as dummies for any casualties of special assault corps from the municipality, any casualties in the highest-mortality battles, and any casualties among volunteers from the municipality). Column 6 additionally includes agricultural controls (share of day laborers, share of sharecroppers and a dummy for the presence of local agrarian associations) and urban controls (industry workers and industrial firms over male population in 1911, literacy rate in 1911, the share of entrepreneurs and rentiers, and the share of the bourgeoisie). Standard errors clustered at the district level are in parentheses. 
Table A4: 2SLS estimates of the effects of Socialist vote share in 1919 on Fascist vote share in 1924 controlling for Fascist vote share in 1919

\begin{tabular}{lcccccc}
\hline Dep variable: Fascist vote share in 1924 & $(1)$ & $(2)$ & $(3)$ & $(4)$ & $(5)$ & $(6)$ \\
\hline Socialist vote share in 1919 & 0.373 & 0.426 & 0.473 & 0.493 & 0.478 & 0.463 \\
& $(0.161)$ & $(0.152)$ & $(0.156)$ & $(0.152)$ & $(0.159)$ & $(0.152)$ \\
Fascist share in 1919 & 0.138 & 0.336 & 0.333 & 0.293 & 0.287 & 0.318 \\
& $(0.161)$ & $(0.119)$ & $(0.121)$ & $(0.122)$ & $(0.123)$ & $(0.125)$ \\
& & & & & & \\
Regiment/Province FE & $\checkmark$ & $\checkmark$ & $\checkmark$ & $\checkmark$ & $\checkmark$ & $\checkmark$ \\
Demographic controls & $\checkmark$ & $\checkmark$ & $\checkmark$ & $\checkmark$ & $\checkmark$ & $\checkmark$ \\
Geographic controls & & $\checkmark$ & $\checkmark$ & $\checkmark$ & $\checkmark$ & $\checkmark$ \\
Socialist share in 1913 & & & $\checkmark$ & $\checkmark$ & $\checkmark$ & $\checkmark$ \\
Military controls & & & & $\checkmark$ & $\checkmark$ & $\checkmark$ \\
Agriculture controls & & & & & $\checkmark$ & $\checkmark$ \\
Urban controls & & & & & & $\checkmark$ \\
Observations & 5,775 & 5,775 & 5,775 & 5,775 & 5,775 & 5,775 \\
Number of clusters & 181 & 181 & 181 & 181 & 181 & 181 \\
1st Stage F-stat & 41.93 & 42.70 & 57.31 & 58 & 54.55 & 52.83 \\
\hline
\end{tabular}

Notes: 2SLS regressions of the Fascist vote share in 1924 on the Socialist vote share in 1919 controlling for Fascist vote share in 1919. The excluded instrument is the count of footsoldier casualties from a municipality divided by the total male population over the age of six in 1911. Column 1 includes regiment and province fixed effects and demographic controls (quartic in log population and share of population below the age of six in 1911). Column 2 additionally includes geographic controls (log area, elevation of the main center, and maximum elevation). Column 3 adds Socialist vote share in 1913. Column 4 adds military controls (veterans from classes 1874-1895 and from classes 1896-1900 as well as dummies for any casualties of special assault corps from the municipality, any casualties in the highest-mortality battles, and any casualties among volunteers from the municipality). Column 5 additionally includes agricultural controls (share of day laborers, share of sharecroppers and a dummy for the presence of local agrarian associations). Finally column 6 adds urban controls (industry workers and industrial firms over male population in 1911, literacy rate in 1911, the share of entrepreneurs and rentiers, and the share of the bourgeoisie). Standard errors clustered at the district level are in parentheses. 
Table A5: 2SLS estimates of the effects of Socialist vote share in 1919 on measures of Fascist support excluding the South of Italy from the sample

\begin{tabular}{|c|c|c|c|c|}
\hline Dep variable: & $\begin{array}{c}\text { Socialist vote share } \\
\text { in } 1919\end{array}$ & $\begin{array}{c}\text { Fascist vote share } \\
\text { in } 1924\end{array}$ & $\begin{array}{l}\text { Fascist violence } \\
\text { in } 1920-2\end{array}$ & $\begin{array}{c}\text { Fascist branches } \\
\text { in } 1921\end{array}$ \\
\hline & (1) (2) & (4) & (6) & (7) \\
\hline
\end{tabular}

$\begin{array}{ccc}\text { Share of footsoldier casualties } & 2.164 & 2.066 \\ & (0.268) & (0.274)\end{array}$

Socialist vote share in 1919

$\begin{array}{cccccc}0.444 & 0.400 & 0.273 & 0.251 & 0.777 & 0.810 \\ (0.141) & (0.140) & (0.112) & (0.111) & (0.281) & (0.282)\end{array}$

$\begin{array}{lcccccccc}\text { Regiment/Province FE } & \checkmark & \checkmark & \checkmark & \checkmark & \checkmark & \checkmark & & \checkmark \\ \text { Demographic controls } & \checkmark & \checkmark & \checkmark & \checkmark & \checkmark & \checkmark & \checkmark & \checkmark \\ \text { Geographic controls } & \checkmark & \checkmark & \checkmark & \checkmark & \checkmark & \checkmark & \checkmark & \checkmark \\ \text { Socialist share in 1913 } & \checkmark & \checkmark & \checkmark & \checkmark & \checkmark & \checkmark & \checkmark & \checkmark \\ \text { Military controls } & \checkmark & \checkmark & \checkmark & \checkmark & \checkmark & \checkmark & \checkmark & \checkmark \\ \text { Agriculture controls } & & \checkmark & & \checkmark & & \checkmark & & \checkmark \\ \text { Urban controls } & & \checkmark & & \checkmark & & \checkmark & & \\ \text { Observations } & 4,571 & 4,571 & 4,571 & 4,571 & 4,571 & 4,571 & 4,571 & 4,571 \\ \text { Number of clusters } & 122 & 122 & 122 & 122 & 122 & 122 & 122 & 122 \\ \text { 1st stage F-stat } & 65.19 & 57.04 & & & & & & \end{array}$

Notes: 2SLS regressions of the Fascist vote share in 1924 (columns 3 and 4), Fascist branches in 1921 (columns 5 and 6) and Fascist violence between 1920 and 1922 (columns 7 and 8) on the Socialist vote share in 1919. First stage results are reported in columns 1 and 2. The excluded instrument is the count of footsoldier casualties from a municipality divided by the total male population over the age of six in 1911. We exclude the South of Italy from the sample. The two specifications correspond to those from columns 4 and 6 in Table 1 . Column 4 includes regiment and province fixed effects and demographic controls (quartic in log population and share of population below the age of six in 1911), geographic controls (log area, elevation of the main center, and maximum elevation), the Socialist vote share in 1913, and military controls (veterans from classes 1874-1895 and from classes 1896-1900 as well as dummies for any casualties of special assault corps from the municipality, any casualties in the highest-mortality battles, and any casualties among volunteers from the municipality). Column 6 additionally includes agricultural controls (share of day laborers, share of sharecroppers and a dummy for the presence of local agrarian associations) and urban controls (industry workers and industrial firms over male population in 1911, literacy rate in 1911, the share of entrepreneurs and rentiers, and the share of the bourgeoisie). Standard errors clustered at the district level are in parentheses. 
Table A6: 2SLS estimates of the effects of Socialist vote share in 1919 on Fascist vote share in 1924 defined using only the official lists

\begin{tabular}{lcccccc}
\hline \multicolumn{2}{l}{ Dep variable: Fascist vote share in 1924 (official lists only) } & & & \\
& (1) & (2) & (3) & (4) & (5) & $(6)$ \\
\hline Socialist vote share in 1919 & 0.317 & 0.369 & 0.408 & 0.434 & 0.419 & 0.407 \\
& $(0.166)$ & $(0.159)$ & $(0.167)$ & $(0.165)$ & $(0.171)$ & $(0.164)$ \\
& & & & & & \\
Regiment/Province FE & $\checkmark$ & $\checkmark$ & $\checkmark$ & $\checkmark$ & $\checkmark$ & $\checkmark$ \\
Demographic controls & $\checkmark$ & $\checkmark$ & $\checkmark$ & $\checkmark$ & $\checkmark$ & $\checkmark$ \\
Geographic controls & & $\checkmark$ & $\checkmark$ & $\checkmark$ & $\checkmark$ & $\checkmark$ \\
Socialist share in 1913 & & & $\checkmark$ & $\checkmark$ & $\checkmark$ & $\checkmark$ \\
Military controls & & & & $\checkmark$ & $\checkmark$ & $\checkmark$ \\
Agriculture controls & & & & & $\checkmark$ & $\checkmark$ \\
Urban controls & & & & & & $\checkmark$ \\
Observations & 5,775 & 5,775 & 5,775 & 5,775 & 5,775 & 5,775 \\
Number of clusters & 181 & 181 & 181 & 181 & 181 & 181 \\
\hline
\end{tabular}

Notes: 2SLS regressions of the Fascist vote share in 1924 (only official lists) on the Socialist vote share in 1919. The excluded instrument in the first stage is the count of footsoldier casualties during WWI over male population over six years old in 1911. Column 1 includes regiment and province fixed effects and demographic controls (quartic in log population and share of population below the age of six in 1911). Column 2 additionally includes geographic controls (log area, elevation of the main center, and maximum elevation). Column 3 adds Socialist vote share in 1913. Column 4 adds military controls (veterans from classes 1874-1895 and from classes 1896-1900 as well as dummies for any casualties of special assault corps from the municipality, any casualties in the highest-mortality battles, and any casualties among volunteers from the municipality). Column 5 additionally includes agricultural controls (share of day laborers, share of sharecroppers and a dummy for the presence of local agrarian associations). Finally column 6 adds urban controls (industry workers and industrial firms over male population in 1911, literacy rate in 1911, the share of entrepreneurs and rentiers, and the share of the bourgeoisie). Standard errors clustered at the district level are in parentheses. 
Table A7: 2SLS estimates of the relationship between Socialist vote share in 1919 and Fascist support using alternative measures of WWI casualties

\section{(1)}

(2)

(3)

(4)

(5)

(6)

Panel A:

Dep variable: Fascist vote share in 1924

Socialist vote share in 1919

$\begin{array}{cccccc}0.533 & 0.512 & 0.604 & 0.628 & 0.554 & 0.535 \\ (0.159) & (0.162) & (0.234) & (0.250) & (0.162) & (0.160)\end{array}$

Panel B:

Dep variable: Fascist violence in 1920-2

$\begin{array}{ccccccc}\text { Socialist vote share in } 1919 & 0.369 & 0.360 & 0.315 & 0.313 & 0.344 & 0.337 \\ & (0.141) & (0.139) & (0.173) & (0.181) & (0.123) & (0.120)\end{array}$

Panel C:

Dep variable: Fascist local branches in 1921

$\begin{array}{ccccccc}\text { Socialist vote share in } 1919 & 0.599 & 0.611 & 1.134 & 1.191 & 0.600 & 0.630 \\ & (0.266) & (0.256) & (0.337) & (0.344) & (0.296) & (0.279)\end{array}$

Casualties among reservist \&

drafted footsoldiers

Casualties among drafted

footsoldiers

Casualties among

all soldiers

Regiment/Province FE

Demographic controls

Geographic controls

Socialist share in 1913

Military controls

Agriculture controls

Urban controls

$(0.266)$

$0.256)$

$(0.337)$

Observations

5,775

$\begin{array}{ll}\checkmark & \checkmark \\ \checkmark & \checkmark \\ \checkmark & \checkmark \\ \checkmark & \checkmark \\ \checkmark & \checkmark \\ & \checkmark \\ & \checkmark\end{array}$
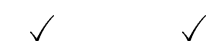

Number of clusters

181

$\begin{array}{ll}\checkmark & \checkmark \\ \checkmark & \checkmark \\ \checkmark & \checkmark \\ \checkmark & \checkmark \\ \checkmark & \checkmark \\ & \checkmark \\ & \checkmark\end{array}$

Notes: 2SLS regressions of the Fascist vote share in 1924 (Panel A), Fascist violence in 1920-22 (Panel B) and the presence of Fascist branches in 1921 (Panel C) on the Socialist vote share in 1919. In columns 1 and 2 the excluded instrument is defined using the number of casualties from men drafted and reservists. Columns 3 and 4 use only the number of casualties from men drafted to construct the excluded instrument while columns 5 and 6 use casualties from all soldiers. All versions of the instrument are computed in shares, dividing the count of casualties by the total male population over six years old in 1911. The two specifications correspond to those from columns 4 and 6 in Table 1 . Column 4 includes regiment and province fixed effects and demographic controls (quartic in log population and share of population below the age of six in 1911), geographic controls (log area, elevation of the main center, and maximum elevation), the Socialist vote share in 1913, and military controls (veterans from classes 1874-1895 and from classes 1896-1900 as well as dummies for any casualties of special assault corps from the municipality, any casualties in the highest-mortality battles, and any casualties among volunteers from the municipality). Column 6 additionally includes agricultural controls (share of day laborers, share of sharecroppers and a dummy for the presence of local agrarian associations) and urban controls (industry workers and industrial firms over male population in 1911, literacy rate in 1911, the share of entrepreneurs and rentiers, and the share of the bourgeoisie). Standard errors clustered at the district level are in parentheses. 
Table A8: 2SLS estimates of the relationship between Socialist vote share in 1919, Fascist votes in 1921 elections and alternative definitions of Fascist violence

\begin{tabular}{|c|c|c|c|c|c|c|}
\hline & $(1)$ & $(2)$ & (3) & $(4)$ & $(5)$ & (6) \\
\hline $\begin{array}{l}\text { Panel A: } \\
\text { Dep variable: }\end{array}$ & \multicolumn{2}{|c|}{$\begin{array}{l}\text { Fascist vote } \\
\text { share in } 1921\end{array}$} & \multicolumn{2}{|c|}{$\begin{array}{l}\text { Fascist vote } \\
\text { in } 1921 \text { dummy }\end{array}$} & \multicolumn{2}{|c|}{$\begin{array}{l}\text { Fascist and National } \\
\text { Blocks share in } 1921\end{array}$} \\
\hline Socialist vote share in 1919 & $\begin{array}{c}0.013 \\
(0.007)\end{array}$ & $\begin{array}{c}0.013 \\
(0.007)\end{array}$ & $\begin{array}{c}0.052 \\
(0.026)\end{array}$ & $\begin{array}{c}0.054 \\
(0.028)\end{array}$ & $\begin{array}{l}-0.154 \\
(0.181)\end{array}$ & $\begin{array}{l}-0.190 \\
(0.172)\end{array}$ \\
\hline $\begin{array}{l}\text { Observations } \\
\text { Number of clusters }\end{array}$ & $\begin{array}{c}5,084 \\
172\end{array}$ & $\begin{array}{c}5,084 \\
172\end{array}$ & $\begin{array}{c}5,084 \\
172\end{array}$ & $\begin{array}{c}5,084 \\
172\end{array}$ & $\begin{array}{c}5,084 \\
172\end{array}$ & $\begin{array}{c}5,084 \\
172\end{array}$ \\
\hline $\begin{array}{l}\text { Panel B: } \\
\text { Dep variable: }\end{array}$ & \multicolumn{2}{|c|}{$\begin{array}{l}\text { Fascist killings } \\
\quad \text { in } 1920-2\end{array}$} & \multicolumn{2}{|c|}{$\begin{array}{l}\text { Political violence } \\
\text { in } 1920-2\end{array}$} & \multicolumn{2}{|c|}{$\begin{array}{l}\text { Non-fascist violence } \\
\text { in } 1920-2\end{array}$} \\
\hline Socialist vote share in 1919 & $\begin{array}{c}0.091 \\
(0.046)\end{array}$ & $\begin{array}{c}0.093 \\
(0.045)\end{array}$ & $\begin{array}{c}0.326 \\
(0.128)\end{array}$ & $\begin{array}{c}0.307 \\
(0.123)\end{array}$ & $\begin{array}{l}-0.006 \\
(0.021)\end{array}$ & $\begin{array}{l}-0.008 \\
(0.021)\end{array}$ \\
\hline Observations & 5,775 & 5,775 & 5,775 & 5,775 & 5,775 & 5,775 \\
\hline Number of clusters & 181 & 181 & 181 & 181 & 181 & 181 \\
\hline Regiment/Province FE & $\checkmark$ & $\checkmark$ & $\checkmark$ & $\checkmark$ & $\checkmark$ & $\checkmark$ \\
\hline Demographic controls & $\checkmark$ & $\checkmark$ & $\checkmark$ & $\checkmark$ & $\checkmark$ & $\checkmark$ \\
\hline Geographic controls & $\checkmark$ & $\checkmark$ & $\checkmark$ & $\checkmark$ & $\checkmark$ & $\checkmark$ \\
\hline Socialist share in 1913 & $\checkmark$ & $\checkmark$ & $\checkmark$ & $\checkmark$ & $\checkmark$ & $\checkmark$ \\
\hline Military controls & $\checkmark$ & $\checkmark$ & $\checkmark$ & $\checkmark$ & $\checkmark$ & $\checkmark$ \\
\hline Agriculture controls & & $\checkmark$ & & $\checkmark$ & & $\checkmark$ \\
\hline Urban controls & & $\checkmark$ & & $\checkmark$ & & $\checkmark$ \\
\hline
\end{tabular}

Notes: 2SLS regressions of alternative measure of the Fascist vote share in 1921 (Panel A) and alternative measures of Fascist violence in 1920-22 (Panel B) on the Socialist vote share in 1919. The left-hand side variables in Panel A are: the Fascist vote share in 1921, a dummy for Fascists receiving a positive number of votes in 1921, and the aggregate vote share of Fascists and National blocks in 1921. In Panel B we consider: the number of killings per 1000 inhabitants in 1920-2 perpetrated by Fascists, the number of violent episodes per 1000 inhabitants in 1920-2 by any perpetrator, and the number of violent episodes excluding Fascist violence. The two specifications correspond to those from columns 4 and 6 in Table 1. Column 4 includes regiment and province fixed effects and demographic controls (quartic in log population and share of population below the age of six in 1911), geographic controls (log area, elevation of the main center, and maximum elevation), the Socialist vote share in 1913, and military controls (veterans from classes 1874-1895 and from classes 18961900 as well as dummies for any casualties of special assault corps from the municipality, any casualties in the highest-mortality battles, and any casualties among volunteers from the municipality). Column 6 additionally includes agricultural controls (share of day laborers, share of sharecroppers and a dummy for the presence of local agrarian associations) and urban controls (industry workers and industrial firms over male population in 1911, literacy rate in 1911, the share of entrepreneurs and rentiers, and the share of the bourgeoisie). Standard errors clustered at the district level are in parentheses. 
Table A9: 2SLS estimates of the relationship between Socialist vote share in 1919 and Fascist support using alternative fixed effects specifications

$\begin{array}{llll}\text { Dep variable: } & \text { Fascist vote share in } 1924 & \text { Fascist violence in 1920-2 local branches in } 1921\end{array}$

\begin{tabular}{|c|c|c|c|c|c|c|c|c|c|c|c|c|}
\hline & $(1)$ & $(2)$ & (3) & (4) & (5) & (6) & (7) & (8) & (9) & $(10)$ & $(11)$ & $(12)$ \\
\hline Socialist vote share in 1919 & $\begin{array}{c}0.457 \\
(0.174)\end{array}$ & $\begin{array}{c}0.406 \\
(0.168)\end{array}$ & $\begin{array}{c}0.391 \\
(0.159)\end{array}$ & $\begin{array}{c}0.352 \\
(0.159)\end{array}$ & $\begin{array}{c}0.316 \\
(0.131)\end{array}$ & $\begin{array}{c}0.281 \\
(0.119)\end{array}$ & $\begin{array}{c}0.305 \\
(0.131)\end{array}$ & $\begin{array}{c}0.281 \\
(0.122)\end{array}$ & $\begin{array}{c}0.700 \\
(0.307)\end{array}$ & $\begin{array}{c}0.655 \\
(0.276)\end{array}$ & $\begin{array}{c}0.683 \\
(0.330)\end{array}$ & $\begin{array}{c}0.664 \\
(0.311)\end{array}$ \\
\hline Province FE & $\checkmark$ & $\checkmark$ & $\checkmark$ & $\checkmark$ & $\checkmark$ & $\checkmark$ & $\checkmark$ & $\checkmark$ & $\checkmark$ & $\checkmark$ & $\checkmark$ & $\checkmark$ \\
\hline Demographic controls & $\checkmark$ & $\checkmark$ & $\checkmark$ & $\checkmark$ & $\checkmark$ & $\checkmark$ & $\checkmark$ & $\checkmark$ & $\checkmark$ & $\checkmark$ & $\checkmark$ & $\checkmark$ \\
\hline Geographic controls & $\checkmark$ & $\checkmark$ & $\checkmark$ & $\checkmark$ & $\checkmark$ & $\checkmark$ & $\checkmark$ & $\checkmark$ & $\checkmark$ & $\checkmark$ & $\checkmark$ & $\checkmark$ \\
\hline Socialist share in 1913 & $\checkmark$ & $\checkmark$ & $\checkmark$ & $\checkmark$ & $\checkmark$ & $\checkmark$ & $\checkmark$ & $\checkmark$ & $\checkmark$ & $\checkmark$ & $\checkmark$ & $\checkmark$ \\
\hline Military controls & $\checkmark$ & $\checkmark$ & $\checkmark$ & $\checkmark$ & $\checkmark$ & $\checkmark$ & $\checkmark$ & $\checkmark$ & $\checkmark$ & $\checkmark$ & $\checkmark$ & $\checkmark$ \\
\hline Agriculture controls & & $\checkmark$ & & $\checkmark$ & & $\checkmark$ & & $\checkmark$ & & $\checkmark$ & & $\checkmark$ \\
\hline Urban controls & & $\checkmark$ & & $\checkmark$ & & $\checkmark$ & & $\checkmark$ & & $\checkmark$ & & $\checkmark$ \\
\hline Front Semester FE & $\checkmark$ & $\checkmark$ & & & $\checkmark$ & $\checkmark$ & & & $\checkmark$ & $\checkmark$ & & \\
\hline Front Month FE & & & $\checkmark$ & $\checkmark$ & & & $\checkmark$ & $\checkmark$ & & & $\checkmark$ & $\checkmark$ \\
\hline Observations & 5,775 & 5,775 & 5,775 & 5,775 & 5,775 & 5,775 & 5,775 & 5,775 & 5,775 & 5,775 & 5,775 & 5,775 \\
\hline Number of clusters & 181 & 181 & 181 & 181 & 181 & 181 & 181 & 181 & 181 & 181 & 181 & 181 \\
\hline 1st Stage F-stat & 42.17 & 42.45 & 39.72 & 37.74 & 42.17 & 42.45 & 39.72 & 37.74 & 42.17 & 42.45 & 39.72 & 37.74 \\
\hline
\end{tabular}

Notes: 2SLS regressions of the Fascist vote share in 1924 (columns 1 to 4), Fascist violence in 1920-22 (columns 5 to 8) and the presence of Fascist branches in 1921 (columns 9 to 12) on the Socialist vote share in 1919. Excluded instrument is the count of footsoldier casualties from a municipality divided by the total male population over the age of six in 1911. The two specifications correspond to those from columns 4 and 6 in Table 1 except for regiment fixed effects replaced by either front-semester fixed effects (columns 1-2, 5-6, 9-10) or front-month fixed effects (columns 3-4, 7-8, 11-12). Column 4 includes province fixed effects and demographic controls (quartic in log population and share of population below the age of six in 1911), geographic controls (log area, elevation of the main center, and maximum elevation), the Socialist vote share in 1913, and military controls (veterans from classes 1874-1895 and from classes 1896-1900 as well as dummies for any casualties of special assault corps from the municipality, any casualties in the highest-mortality battles, and any casualties among volunteers from the municipality). Column 6 additionally includes agricultural controls (share of day laborers, share of sharecroppers and a dummy for the presence of local agrarian associations) and urban controls (industry workers and industrial firms over male population in 1911, literacy rate in 1911, the share of entrepreneurs and rentiers, and the share of the bourgeoisie). Standard errors clustered at the district level are in parentheses. 
Table A10: 2SLS estimates of the effects of Socialist vote share in 1919 on vote share of other main parties in 1924

\begin{tabular}{|c|c|c|c|c|c|c|c|c|c|c|c|c|}
\hline Dep variable: Party's vote & $\begin{array}{l}\text { re in } 192 \\
\text { (1) }\end{array}$ & $(2)$ & (3) & (4) & (5) & (6) & (7) & (8) & (9) & $(10)$ & $(11)$ & $(12)$ \\
\hline \multicolumn{13}{|c|}{ Panel A: Controlling for 1919 vote shares } \\
\hline Socialist vote share in 1919 & $\begin{array}{l}-0.155 \\
(0.131)\end{array}$ & $\begin{array}{l}-0.122 \\
(0.123)\end{array}$ & $\begin{array}{l}-0.003 \\
(0.017)\end{array}$ & $\begin{array}{l}-0.009 \\
(0.020)\end{array}$ & $\begin{array}{c}0.012 \\
(0.044)\end{array}$ & $\begin{array}{c}0.008 \\
(0.046)\end{array}$ & $\begin{array}{c}0.005 \\
(0.052)\end{array}$ & $\begin{array}{c}0.009 \\
(0.054)\end{array}$ & $\begin{array}{l}-0.279 \\
(0.072)\end{array}$ & $\begin{array}{c}-0.294 \\
(0.078)\end{array}$ & $\begin{array}{c}0.000 \\
(0.020)\end{array}$ & $\begin{array}{l}-0.007 \\
(0.022)\end{array}$ \\
\hline Vote share in 1919 & $\begin{array}{c}0.229 \\
(0.067)\end{array}$ & $\begin{array}{c}0.239 \\
(0.064)\end{array}$ & $\begin{array}{c}0.389 \\
(0.032)\end{array}$ & $\begin{array}{c}0.383 \\
(0.031)\end{array}$ & $\begin{array}{c}0.018 \\
(0.020)\end{array}$ & $\begin{array}{c}0.016 \\
(0.021)\end{array}$ & $\begin{array}{c}0.018 \\
(0.015)\end{array}$ & $\begin{array}{c}0.019 \\
(0.014)\end{array}$ & $\begin{array}{l}-0.206 \\
(0.076)\end{array}$ & $\begin{array}{c}-0.211 \\
(0.075)\end{array}$ & $\begin{array}{c}0.018 \\
(0.016)\end{array}$ & $\begin{array}{c}0.017 \\
(0.016)\end{array}$ \\
\hline
\end{tabular}

Panel B: No control for 1919 party vote shares

$\begin{array}{cccccccccccccc}\text { Socialist vote share in } 1919 & -0.308 & -0.273 & 0.003 & -0.003 & 0.013 & 0.011 & 0.010 & 0.014 & -0.276 & -0.294 & 0.003 & -0.004 \\ & (0.110) & (0.104) & (0.017) & (0.020) & (0.036) & (0.037) & (0.055) & (0.056) & (0.071) & (0.078) & (0.021) & (0.022)\end{array}$

Party considered:

Mean vote share in 1919

Regiment/Province FE

Demographic controls

Geographic controls

Socialist share in 1913

Military controls

Agriculture controls

Urban controls

\begin{tabular}{|c|c|c|}
\hline \multicolumn{2}{|c|}{$\begin{array}{c}\text { Popular } \\
0.272\end{array}$} & $\begin{array}{c}\text { Republican } \\
0.004\end{array}$ \\
\hline$\checkmark$ & $\checkmark$ & $\checkmark$ \\
\hline$\checkmark$ & $\checkmark$ & $\checkmark$ \\
\hline$\checkmark$ & $\checkmark$ & $\checkmark$ \\
\hline$\checkmark$ & $\checkmark$ & $\checkmark$ \\
\hline$\checkmark$ & $\checkmark$ & $\checkmark$ \\
\hline & $\checkmark$ & \\
\hline & $\checkmark$ & \\
\hline
\end{tabular}

\begin{tabular}{cc}
\multicolumn{2}{c}{ Democratic } \\
\multicolumn{3}{c}{0.222} & \\
$\checkmark$ & $\checkmark$ \\
$\checkmark$ & \\
$\checkmark$ & $\checkmark$ \\
$\checkmark$ & $\checkmark$ \\
$\checkmark$ & $\checkmark$ \\
& $\checkmark$ \\
& $\checkmark$ \\
& $\checkmark$
\end{tabular}

\begin{tabular}{ccc}
\multicolumn{3}{c}{ Liberal } \\
\multicolumn{3}{c}{0.096} \\
$\checkmark$ & \\
$\checkmark$ & & $\checkmark$ \\
$\checkmark$ & & $\checkmark$ \\
$\checkmark$ & & $\checkmark$ \\
$\checkmark$ & & $\checkmark$ \\
& & $\checkmark$ \\
& & $\checkmark$
\end{tabular}

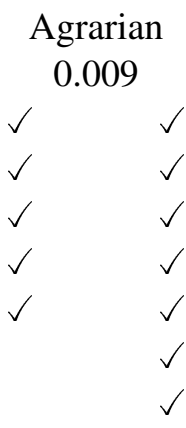

Left Liberal 0.011

Notes: 2SLS regressions of the vote shares of other main parties competing in the 1924 national elections other than the Fascist party on Socialist vote share in 1919 . Panel A presents results controlling for the same party electoral share in 1919, while Panel B presents results without controlling for the party 1919 electoral share. We also report the mean vote share of each party in 1919. The two specifications correspond to those from columns 4 and 6 in Table 1 . Column 4 includes regiment and province fixed effects and demographic controls (quartic in log population and share of population below the age of six in 1911), geographic controls (log area, elevation of the main center, and maximum elevation), the Socialist vote share in 1913, and military controls (veterans from classes 1874-1895 and from classes 1896-1900 as well as dummies for any casualties of special assault corps from the municipality, any casualties in the highest-mortality battles, and any casualties among volunteers from the municipality). Column 6 additionally includes agricultural controls (share of day laborers, share of sharecroppers and a dummy for the presence of local agrarian associations) and urban controls (industry workers and industrial firms over male population in 1911, literacy rate in 1911, the share of entrepreneurs and rentiers, and the share of the bourgeoisie). Standard errors clustered at the district level are in parentheses. 
Table A11: Heterogeneous effects of Socialist vote share in 1919 on the presence of large donors for the Fascist party

\begin{tabular}{|c|c|c|c|c|}
\hline \multicolumn{5}{|c|}{ Dep variable: Large donor dummy (1919-25) } \\
\hline & (1) & (2) & (3) & (4) \\
\hline \multirow[t]{2}{*}{ Socialist vote share in 1919} & 0.013 & 0.033 & -0.005 & 0.020 \\
\hline & $(0.095)$ & $(0.096)$ & $(0.102)$ & $(0.105)$ \\
\hline \multirow[t]{2}{*}{ Socialists $\mathrm{x}$ elite variable } & 0.438 & 0.421 & 8.555 & 10.783 \\
\hline & $(0.217)$ & $(0.209)$ & $(5.606)$ & $(6.472)$ \\
\hline Elite variable & \multicolumn{2}{|c|}{$\begin{array}{l}\text { Landowner } \\
\text { ass. dummy }\end{array}$} & \multicolumn{2}{|c|}{$\begin{array}{c}\text { Share of } \\
\text { elites }\end{array}$} \\
\hline Regiment/Province FE & $\checkmark$ & $\checkmark$ & $\checkmark$ & $\checkmark$ \\
\hline Demographic controls & $\checkmark$ & $\checkmark$ & $\checkmark$ & $\checkmark$ \\
\hline Geographic controls & $\checkmark$ & $\checkmark$ & $\checkmark$ & $\checkmark$ \\
\hline Socialist share in 1913 & $\checkmark$ & $\checkmark$ & $\checkmark$ & $\checkmark$ \\
\hline Military controls & $\checkmark$ & $\checkmark$ & $\checkmark$ & $\checkmark$ \\
\hline Agriculture controls & & $\checkmark$ & & $\checkmark$ \\
\hline Urban controls & & $\checkmark$ & & $\checkmark$ \\
\hline Observations & 5,775 & 5,775 & 5,775 & 5,775 \\
\hline Number of clusters & 181 & 181 & 181 & 181 \\
\hline Kleibergen Paap F-stat & 27.37 & 25.53 & 16.73 & 13.41 \\
\hline
\end{tabular}

Notes: 2SLS regressions of the heterogeneous effect of the Socialist vote share in 1919 on a dummy for the presence of large donors to the Fascist Party in the period 1919-1925 in the presence of landowners' associations (columns 1 and 2) and the share of elites (columns 3 and 4). The endogenous variables are Socialist vote share in 1919 and its interaction with the measure of elite organization. Excluded instruments are the count of WWI footsoldier casualties from a municipality divided by the total male population over the age of six in 1911 and its interaction with the elite variables. The two specifications correspond to those from columns 4 and 6 in Table 1. Column 4 includes regiment and province fixed effects and demographic controls (quartic in log population and share of population below the age of six in 1911), geographic controls (log area, elevation of the main center, and maximum elevation), the Socialist vote share in 1913, and military controls (veterans from classes 1874-1895 and from classes 1896-1900 as well as dummies for any casualties of special assault corps from the municipality, any casualties in the highest-mortality battles, and any casualties among volunteers from the municipality). Column 6 additionally includes agricultural controls (share of day laborers, share of sharecroppers and a dummy for the presence of local agrarian associations) and urban controls (industry workers and industrial firms over male population in 1911, literacy rate in 1911, the share of entrepreneurs and rentiers, and the share of the bourgeoisie). Standard errors clustered at the district level are in parentheses. 
Table A12: Reduced-form estimates of the relationship between footsoldier casualties and measures of local Fascist support

\begin{tabular}{lcccccc}
\hline Dep variable: & \multicolumn{2}{c}{$\begin{array}{c}\text { Fascist vote share } \\
\text { in } 1924\end{array}$} & \multicolumn{2}{c}{$\begin{array}{c}\text { Fascist violence } \\
\text { in 1920-2 }\end{array}$} & \multicolumn{2}{c}{$\begin{array}{c}\text { Fascist branches } \\
\text { in 1921 }\end{array}$} \\
& $(1)$ & $(2)$ & $(3)$ & $(4)$ & $(5)$ & $(6)$ \\
\hline Share of footsoldier casualties & 0.883 & 0.804 & 0.576 & 0.526 & 1.175 & 1.135 \\
& $(0.264)$ & $(0.258)$ & $(0.214)$ & $(0.200)$ & $(0.463)$ & $(0.418)$ \\
& & & & & & \\
Regiment/Province FE & $\checkmark$ & $\checkmark$ & $\checkmark$ & $\checkmark$ & $\checkmark$ & $\checkmark$ \\
Demographic controls & $\checkmark$ & $\checkmark$ & $\checkmark$ & $\checkmark$ & $\checkmark$ & $\checkmark$ \\
Geographic controls & $\checkmark$ & $\checkmark$ & $\checkmark$ & $\checkmark$ & $\checkmark$ & $\checkmark$ \\
Socialist share in 1913 & $\checkmark$ & $\checkmark$ & $\checkmark$ & $\checkmark$ & $\checkmark$ & $\checkmark$ \\
Military controls & $\checkmark$ & $\checkmark$ & $\checkmark$ & $\checkmark$ & $\checkmark$ & $\checkmark$ \\
Agriculture controls & & $\checkmark$ & & $\checkmark$ & & $\checkmark$ \\
Urban controls & & $\checkmark$ & & $\checkmark$ & & $\checkmark$ \\
Observations & & & & & & \\
Number of clusters & 5,775 & 5,775 & 5,775 & 5,775 & 5,775 & 5,775 \\
\hline
\end{tabular}

Notes: Reduced-form regressions of the Fascist vote share in 1924 (columns 1 and 2), Fascist violence between 1920 and 1922 (columns 3 and 4) and Fascist branches in 1921 (columns 5 and 6) on the count of footsoldier casualties during WWI over male population over six years old in 1911. The two specifications correspond to those from columns 4 and 6 in Table 1. Column 4 includes regiment and province fixed effects and demographic controls (quartic in log population and share of population below the age of six in 1911), geographic controls ( $\log$ area, elevation of the main center, and maximum elevation), the Socialist vote share in 1913, and military controls (veterans from classes 1874-1895 and from classes 1896-1900 as well as dummies for any casualties of special assault corps from the municipality, any casualties in the highest-mortality battles, and any casualties among volunteers from the municipality). Column 6 additionally includes agricultural controls (share of day laborers, share of sharecroppers and a dummy for the presence of local agrarian associations) and urban controls (industry workers and industrial firms over male population in 1911, literacy rate in 1911, the share of entrepreneurs and rentiers, and the share of the bourgeoisie). Standard errors clustered at the district level are in parentheses. 
Table A13: Falsification exercises for the Spanish flu excess mortality

\section{(1)}

(2) Socialists in 1913

Dep variable:

Excess Mortality in 1918
(3)

3)

(4)

Literacy in 1911

(5)

$\begin{array}{cc}0.033 & 0.022 \\ (0.017) & (0.016)\end{array}$

Violent crimes in 1874

Crime rate in 1874

$\begin{array}{ll}-0.027 & -0.045 \\ (0.035) & (0.035)\end{array}$

Mean

SD

0.217
0.285

0.352

(0.240)

1.932
1.576
(7)

$-1.351$

(1.031)

8.174

5.840
0.188

Panel B:

Dep variable:

Ind. workers in 1911

5.840

Excess Mortality in 1918

$\begin{array}{cccccccc}0.039 & 0.019 & 0.001 & 0.000 & -0.129 & -0.146 & -0.000 & -0.000 \\ (0.017) & (0.017) & (0.002) & (0.002) & (0.066) & (0.073) & (0.000) & (0.000) \\ & & & & & & & \\ 0.185 & 0.018 & 0.106 & 0.0005 \\ 0.162 & 0.008 & 0.309 & 0.003\end{array}$

Panel C:

Dep variable:

Large landhold.

Many landowners

Agr. strikes in 1913-4

Agr. strikers in 1913-4

Excess Mortality in 1918

$0.011 \quad 0.053$

0.132

0.117

$-0.012 \quad-0.002$

$0.001 \quad 0.002$

(0.095)

(0.098) (0.014)

(0.016)

(0.002)

(0.003)

Mean

0.391

0.489

0.454

0.499

0.015

0.120

0.001

0.019

\begin{abstract}
Regiment/Province FE
Rainfall variance

Demographic controls

Geographic controls

Socialist share in 1913

Military controls

Agriculture controls

Urban controls
\end{abstract}

$\begin{array}{ll}\checkmark & \checkmark \\ \checkmark & \checkmark \\ \checkmark & \checkmark \\ \checkmark & \checkmark \\ \checkmark & \checkmark \\ \checkmark & \checkmark \\ & \checkmark \\ & \checkmark\end{array}$

$\begin{array}{ll}\checkmark & \checkmark \\ \checkmark & \checkmark \\ \checkmark & \checkmark \\ \checkmark & \checkmark \\ \checkmark & \checkmark \\ \checkmark & \checkmark \\ & \checkmark \\ & \checkmark\end{array}$

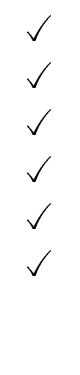

$\checkmark$
$\checkmark$
$\checkmark$
$\checkmark$
$\checkmark$
$\checkmark$
$\checkmark$
$\checkmark$

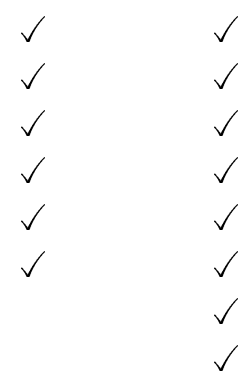

Notes: OLS regressions of the indicated pre-1919 variable on the excess mortality in 1918. Excess mortality is defined as the excess mortality in 1918 from the pre-war mortality computed between 1911 and 1914. The two specifications correspond to those from columns 4 and 6 in Table 1. Column 4 includes regiment and province fixed effects and demographic controls (quartic in log population and share of population below the age of six in 1911), geographic controls (log area, elevation of the main center, and maximum elevation), the Socialist vote share in 1913, and military controls (veterans from classes 1874-1895 and from classes 1896-1900 as well as dummies for any casualties of special assault corps from the municipality, any casualties in the highest-mortality battles, and any casualties among volunteers from the municipality). Column 6 additionally includes agricultural controls (share of day laborers, share of sharecroppers and a dummy for the presence of local agrarian associations) and urban controls (industry workers and industrial firms over male population in 1911, literacy rate in 1911, the share of entrepreneurs and rentiers, and the share of the bourgeoisie). See note to Table 1 and the text for more details. When the left-hand side variable is among the controls included in one of the specifications, it is not included as an additional right-hand side variable. Standard errors clustered at the district level are in parentheses. 
Table A14: Falsification exercises of winter-spring rainfall in 1918-19

(1)

(2)

(3)

(4)

(5)

(6)

(7)

(8)

Panel A:

Dep variable:

Socialists in 1913

Literacy in 1911

Violent crimes in 1874

Crime rate in 1874

Relative winter-spring

$\begin{array}{ll}-0.223 & -0.216 \\ (0.073) & (0.071)\end{array}$

$-0.041 \quad-0.028$

0.000

0.056

$-4.486$

$-4.301$

(0.023)

(0.021)

(0.274)

(0.270)

(1.806)

(1.748)

Mean

0.162

0.760

1.466

6.334

SD

0.223

0.198

1.578

6.315

Panel B:

Dep variable:

Ind. workers in 1911

Ind. firms in 1911

Ind. strikes in 1913-4

Ind. strikers in 1913-4

Relative winter-spring

$\begin{array}{ll}-0.078 & -0.067 \\ (0.031) & (0.028)\end{array}$

$\begin{array}{ll}-0.002 & -0.001 \\ (0.002) & (0.002)\end{array}$

-0.013
$(0.010)$

$-0.010$

$-0.002$

$-0.002$

0.121

0.013

(0.011)

(0.001)

(0.001)

Mean

0.226

0.011

0.009

0.001

0.094

0.014

Panel C:

Dep variable:

Relative winter-spring Large landholding 1885 Landownership 1885

Agr. strikes 1913-4

Agr. strikers 1913-4

$\begin{array}{cccccccc}0.031 & -0.056 & -0.437 & -0.320 & -0.003 & -0.007 & -0.001 & -0.002 \\ (0.196) & (0.187) & (0.129) & (0.122) & (0.006) & (0.006) & (0.001) & (0.001) \\ & 0.432 & 0.581 & 0.002 & 0.0004 \\ & 0.497 & 0.494 & 0.048 & 0.0119\end{array}$

Mean

SD

0.432
0.497

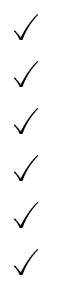

$\checkmark$
$\checkmark$
$\checkmark$
$\checkmark$
$\checkmark$
$\checkmark$
$\checkmark$
$\checkmark$

$\begin{array}{ll}\checkmark & \checkmark \\ \checkmark & \checkmark \\ \checkmark & \checkmark \\ \checkmark & \checkmark \\ \checkmark & \checkmark \\ \checkmark & \checkmark \\ & \checkmark \\ & \checkmark\end{array}$

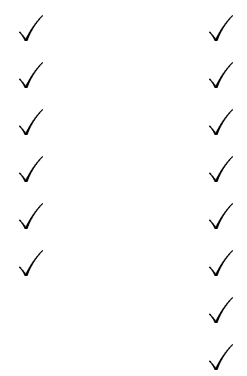

Notes: OLS regressions of the indicated pre-1919 variable on the relative rainfall in winter-spring 1918-9. Relative rainfall is measured at weather station level, using the average for the winter-spring months for the years 1915-1979 as denominator, and then interpolated at municipality level using the inverse of the distances as weights with a cutoff of $30 \mathrm{~km}$. The relative rainfall measure is then capped at 1 in order to consider only negative deviations from the long term average. The two specifications correspond to those from columns 4 and 6 in Table 1 . Column 4 includes regiment and province fixed effects and demographic controls (quartic in log population and share of population below the age of six in 1911), geographic controls (log area, elevation of the main center, and maximum elevation), the Socialist vote share in 1913, and military controls (veterans from classes 1874-1895 and from classes 1896-1900 as well as dummies for any casualties of special assault corps from the municipality, any casualties in the highest-mortality battles, and any casualties among volunteers from the municipality). Column 6 additionally includes agricultural controls (share of day laborers, share of sharecroppers and a dummy for the presence of local agrarian associations) and urban controls (industry workers and industrial firms over male population in 1911, literacy rate in 1911, the share of entrepreneurs and rentiers, and the share of the bourgeoisie). See note to Table 1 and the text for more details. When the left-hand side variable is among the controls included in one of the specifications, it is not included as an additional right-hand side variable. Standard errors reported in parentheses are clustered over two dimensions: the administrative district and the closest weather station. 
Table A15: Falsification exercise - Reduced-form relationship between winter-spring rainfall and Fascist vote share in 1924 between 1917-18 and 1927-28

\begin{tabular}{lccccccccccccc}
\hline Dep variable: Fascist vote share in 1924 & & & & & & & & & & \\
& $(1)$ & $(2)$ & $(3)$ & $(4)$ & $(5)$ & $(6)$ & $(7)$ & $(8)$ & $(9)$ & $(10)$ & $(11)$ \\
\hline Relative winter-spring rainfall & -0.116 & -0.057 & -0.056 & -0.101 & -0.064 & -0.015 & -0.087 & 0.030 & -0.118 & -0.086 & -0.021 \\
& $(0.055)$ & $(0.070)$ & $(0.068)$ & $(0.082)$ & $(0.063)$ & $(0.057)$ & $(0.105)$ & $(0.057)$ & $(0.062)$ & $(0.069)$ & $(0.096)$
\end{tabular}

Regiment/Province FE

Rainfall variance

Demographic controls

Geographic controls

Socialist share in 1913

Military controls

Agriculture controls

Urban controls

\section{Year \\ Mean}

SD

Observations

Number of district clusters

Number of station clusters

$\begin{array}{ll}\checkmark & \checkmark \\ \checkmark & \checkmark \\ \checkmark & \checkmark \\ \checkmark & \checkmark \\ \checkmark & \checkmark \\ \checkmark & \checkmark \\ \checkmark & \checkmark \\ \checkmark & \checkmark\end{array}$

$\begin{array}{ll}\checkmark & \checkmark \\ \checkmark & \checkmark \\ \checkmark & \checkmark \\ \checkmark & \checkmark \\ \checkmark & \checkmark \\ \checkmark & \checkmark \\ \checkmark & \checkmark\end{array}$

$\begin{array}{lll}\checkmark & \checkmark & \checkmark \\ \checkmark & \checkmark & \checkmark \\ \checkmark & \checkmark & \checkmark \\ \checkmark & \checkmark & \checkmark \\ \checkmark & \checkmark & \checkmark \\ \checkmark & \checkmark & \checkmark \\ \checkmark & \checkmark & \checkmark \\ \checkmark & \checkmark & \checkmark\end{array}$

$\begin{array}{ll}\checkmark & \checkmark \\ \checkmark & \checkmark \\ \checkmark & \checkmark \\ \checkmark & \checkmark \\ \checkmark & \checkmark \\ \checkmark & \checkmark \\ \checkmark & \checkmark \\ \checkmark & \checkmark\end{array}$

$\begin{array}{ll}\checkmark & \checkmark \\ \checkmark & \checkmark \\ \checkmark & \checkmark \\ \checkmark & \checkmark \\ \checkmark & \checkmark \\ \checkmark & \checkmark \\ \checkmark & \checkmark \\ \checkmark & \checkmark\end{array}$

Notes: Reduced-form regressions of Fascist vote share in 1924 on the relative rainfall in winter-spring 1918-9 and other 10 years, used as a falsification exercise. Relative rainfall is measured at weather station level, using the average for the winter-spring months for the years 1915-1979 as denominator, and then interpolated at municipality level using the inverse of the distances as weights with a cutoff of $30 \mathrm{~km}$. The relative rainfall measure is then capped at 1 in order to consider only negative deviations from the long term average. In Column (1) we report the coefficient of the reduced form regression of the relative rainfall in winter-spring 1918-9 on Fascist vote share in 1924. In columns 2-11 we report the coefficients of the falsification exercise using the relative rainfall in winter-spring for the years 1917-8 and from 1919-20 to 1927-8. In all columns we include the full set of controls which are the regiment and province fixed effects, the variance of the relative rainfall variable over the period 1915-1979, the demographic controls which consist of log population (quartic polynomial) and the share of population below the age of 6 in 1911; log area, elevation of the main centre, and maximum elevation, the vote share of the Socialist party in 1913, the share of veterans of the classes 1874-95 and 1895-1900 over the male population above 6, and dummies for (i) casualties of members of the special assault corps, (ii) casualties in the most bloody events of the war, and (iii) casualties of volunteers; the agriculture controls: the share of day labourers, the share of share-croppers, and a dummy for the presence of local agrarian associations; and the urban controls: industry workers and industrial firms over male population in 1911, literacy rate in 1911, the share of entrepreneurs and rentiers and the share of bourgeoisie. Standard errors reported in parentheses are clustered over two dimensions: the administrative district and the closest weather station. 
Table A16: 2SLS estimates of the relationship between Fascist vote share in 1924 and Jews deportation 1943-45 (Italian Social Republic sample)

\begin{tabular}{|c|c|c|c|c|c|c|}
\hline & (1) & (2) & (3) & (4) & $(5)$ & $(6)$ \\
\hline \multicolumn{7}{|c|}{ Panel A: Jews deportation dummy (1943-45) - IV } \\
\hline Fascist vote share in 1924 & $\begin{array}{c}0.962 \\
(0.553)\end{array}$ & $\begin{array}{c}0.886 \\
(0.505)\end{array}$ & $\begin{array}{c}0.897 \\
(0.502)\end{array}$ & $\begin{array}{c}0.869 \\
(0.460)\end{array}$ & $\begin{array}{c}0.953 \\
(0.527)\end{array}$ & $\begin{array}{c}0.968 \\
(0.548)\end{array}$ \\
\hline \multicolumn{7}{|c|}{ Panel B: Deportations over Jewish population (capped at 1) - IV } \\
\hline Fascist vote share in 1924 & $\begin{array}{c}0.910 \\
(0.473)\end{array}$ & $\begin{array}{c}0.835 \\
(0.417)\end{array}$ & $\begin{array}{c}0.834 \\
(0.412)\end{array}$ & $\begin{array}{c}0.796 \\
(0.364)\end{array}$ & $\begin{array}{c}0.881 \\
(0.426)\end{array}$ & $\begin{array}{c}0.880 \\
(0.442)\end{array}$ \\
\hline \multicolumn{7}{|c|}{ Panel C: Deportations over Jewish population (cap at 1 no camps) - IV } \\
\hline Fascist vote share in 1924 & $\begin{array}{c}0.783 \\
(0.433)\end{array}$ & $\begin{array}{c}0.728 \\
(0.390)\end{array}$ & $\begin{array}{c}0.723 \\
(0.384)\end{array}$ & $\begin{array}{c}0.688 \\
(0.339)\end{array}$ & $\begin{array}{c}0.765 \\
(0.396)\end{array}$ & $\begin{array}{c}0.766 \\
(0.408)\end{array}$ \\
\hline Regiment/Province FE & $\checkmark$ & $\checkmark$ & $\checkmark$ & $\checkmark$ & $\checkmark$ & $\checkmark$ \\
\hline Demographic controls & $\checkmark$ & $\checkmark$ & $\checkmark$ & $\checkmark$ & $\checkmark$ & $\checkmark$ \\
\hline Share of jewish pop in 1911 & $\checkmark$ & $\checkmark$ & $\checkmark$ & $\checkmark$ & $\checkmark$ & $\checkmark$ \\
\hline Geographic controls & & $\checkmark$ & $\checkmark$ & $\checkmark$ & $\checkmark$ & $\checkmark$ \\
\hline Socialist share in 1913 & & & $\checkmark$ & $\checkmark$ & $\checkmark$ & $\checkmark$ \\
\hline Military controls & & & & $\checkmark$ & $\checkmark$ & $\checkmark$ \\
\hline Agriculture controls & & & & & $\checkmark$ & $\checkmark$ \\
\hline Urban controls & & & & & & $\checkmark$ \\
\hline Observations & 4,788 & 4,788 & 4,788 & 4,788 & 4,788 & 4,788 \\
\hline Number of clusters & 131 & 131 & 131 & 131 & 131 & 131 \\
\hline 1st stage F-stat & 5.417 & 8.386 & 8.981 & 9.488 & 7.460 & 7.828 \\
\hline
\end{tabular}

Notes: 2SLS regressions of: a dummy for the occurrence of Jews deportation in 1943-45 (Panel A); the number of deported Jews in 1943-45 over 1911 Jewish population, capped at 1 (Panel B); the number of deported Jews in 1943-45 over 1911 Jewish population, capped at 1 and excluding 39 municipalities with concentration camps (Panel C) on the Fascist vote share in 1924. Excluded instrument is the count of footsoldier casualties over the total male population over six years old in 1911. Column 1 includes regiment and province fixed effects and demographic controls (quartic in log population and share of population below the age of six in 1911). Column 2 additionally includes geographic controls (log area, elevation of the main center, and maximum elevation). Column 3 adds Socialist vote share in 1913. Column 4 adds military controls (veterans from classes 1874-1895 and from classes 1896-1900 as well as dummies for any casualties of special assault corps from the municipality, any casualties in the highest-mortality battles, and any casualties among volunteers from the municipality). Column 5 additionally includes agricultural controls (share of day laborers, share of sharecroppers and a dummy for the presence of local agrarian associations). Finally column 6 adds urban controls (industry workers and industrial firms over male population in 1911, literacy rate in 1911, the share of entrepreneurs and rentiers, and the share of the bourgeoisie). Standard errors clustered at the district level are in parentheses. 
Table A17: Reduced-form estimates of the relationship between WWI footsoldier casualties and Jews Deportation

(1)
(2)

(3)

(4)

(5)

(6)

Panel A: Jews deportation dummy (1943-45)
0.684 $(0.311)$
0.683

$(0.318)$
0.692

(0.320)

0.709

(0.319)

0.715

$(0.319)$

0.693

$(0.305)$

Panel B: Deportations over Jewish population (capped at 1)

$\begin{array}{lcccccc}\text { Share of footsoldier casualties } & 0.686 & 0.689 & 0.690 & 0.693 & 0.705 & 0.678 \\ & (0.257) & (0.259) & (0.261) & (0.260) & (0.261) & (0.247)\end{array}$

Panel C: Deportations over Jewish population (cap at 1 no camps)

$\begin{array}{lcccccc}\text { Share of footsoldier casualties } & 0.620 & 0.624 & 0.623 & 0.623 & 0.633 & 0.610 \\ & (0.256) & (0.257) & (0.259) & (0.257) & (0.259) & (0.245)\end{array}$

Regiment/Province FE

Demographic controls

Share of jewish pop in 1911

Geographic controls

Socialist share in 1913

Military controls

Agriculture controls

Urban controls

Observations
Number of clusters

$\begin{array}{ll}\checkmark & \checkmark \\ \checkmark & \checkmark \\ \checkmark & \checkmark \\ & \checkmark\end{array}$

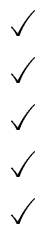

$\checkmark$
$\checkmark$
$\checkmark$
$\checkmark$
$\checkmark$
$\checkmark$

$\begin{array}{ll}\checkmark & \checkmark \\ \checkmark & \checkmark \\ \checkmark & \checkmark \\ \checkmark & \checkmark \\ \checkmark & \checkmark \\ \checkmark & \checkmark \\ \checkmark & \checkmark \\ & \checkmark\end{array}$

$\begin{array}{cccccc}5,775 & 5,775 & 5,775 & 5,775 & 5,775 & 5,775 \\ 181 & 181 & 181 & 181 & 181 & 181\end{array}$

Notes: Reduced-form regressions of: a dummy for the occurrence of Jews deportation in 1943-45 (Panel A); the number of deported Jews in 1943-45 over 1911 Jewish population, capped at 1 (Panel B); the number of deported Jews in 1943-45 over 1911 Jewish population, capped at 1 and excluding 39 municipalities with concentration camps (Panel C) on the count of footsoldier casualties over the total male population over six years old in 1911. Column 1 includes regiment and province fixed effects and demographic controls (quartic in $\log$ population and share of population below the age of six in 1911). Column 2 additionally includes geographic controls (log area, elevation of the main center, and maximum elevation). Column 3 adds Socialist vote share in 1913. Column 4 adds military controls (veterans from classes 1874-1895 and from classes 18961900 as well as dummies for any casualties of special assault corps from the municipality, any casualties in the highest-mortality battles, and any casualties among volunteers from the municipality). Column 5 additionally includes agricultural controls (share of day laborers, share of sharecroppers and a dummy for the presence of local agrarian associations). Finally column 6 adds urban controls (industry workers and industrial firms over male population in 1911, literacy rate in 1911, the share of entrepreneurs and rentiers, and the share of the bourgeoisie). Standard errors clustered at the district level are in parentheses. 